UNIVERSIDADE DE SÃO PAULO

FACULDADE DE FILOSOFIA, LETRAS E CIÊNCIAS HUMANAS DEPARTAMENTO DE SOCIOLOGIA

PROGRAMA DE PÓS-GRADUAÇÃO EM SOCIOLOGIA

GUILHERME BORGES FERREIRA COSTA

\title{
ORTODOXIA EM DOIS TEMPOS \\ DO CLERICALISMO POLÍTICO \\ À SECULARIZAÇÃO ESTATAL
}

São Paulo

2014 
UNIVERSIDADE DE SÃO PAULO

FACULDADE DE FILOSOFIA, LETRAS E CIÊNCIAS HUMANAS

DEPARTAMENTO DE SOCIOLOGIA

PROGRAMA DE PÓS-GRADUAÇÃO EM SOCIOLOGIA

\section{ORTODOXIA EM DOIS TEMPOS \\ DO CLERICALISMO POLÍTICO \\ À SECULARIZAÇÃO ESTATAL}

Guilherme Borges Ferreira Costa

Dissertação apresentada ao Programa de Pós-Graduação do Departamento de Sociologia da Faculdade de Filosofia, Letras e Ciências Humanas da Universidade de São Paulo, para a obtenção do título de Mestre em Sociologia.

Orientadora: Profa. Dra. Maria Helena Oliva Augusto

São Paulo 


\section{Resumo}

O foco desta pesquisa está em observar a influência social do catolicismo conservador no interior da Igreja no Brasil e, para além dos limites clericais, também no que diz respeito ao âmbito jurídico-político nacional. A ideia é analisar o possível prestígio daquelas alas católicas marcadamente ortodoxas e o seu potencial de persuasão, tanto no que se refere às fileiras institucionais eclesiásticas, quanto no que concerne às esferas propriamente estatais. Toma-se como ponto de partida a observação dos embates múltiplos do clero em reação à divulgação oficial do $3^{\circ}$ Programa Nacional de Direitos Humanos (PNDH-3), em finais de 2009. Esse é o material específico da investigação. A escolha desse conjunto bem delimitado de acontecimentos tensos de produção de discursos não menos tensos baseia-se na constatação de uma certa singularidade histórica sua, na qual esses processos aparecem como que revestidos de características novas, para não dizer de um novo caráter, quando comparados com outras conjunturas nada remotas de relações IgrejaEstado em nosso país.

Palavras-chave: Igreja Católica; Conservadorismo; Secularização; Direitos humanos; Sociologia da Religião. 


\begin{abstract}
The subject of the forthcoming research is the social influence of conservative Catholicism within the Church in Brazil and, beyond clerical limits, also in the national legal and political system. The idea is to analyze Catholic conservatism's prestige and its potential ability to persuade, both with regard to institutional ecclesiastical ranks, as well as the state sectors. As a starting point, the research observes several of the clergy's resistances that occur in reaction to the official release of the 3rd National Human Rights Program in late 2009. The research specifically focuses on these resistances. The observation of a unique history, in which these processes appear coated with new features, not to mention a new character when compared with other situations of church-state relations in our country, is the basis for the choice of this well-defined series of tense events, events that produce speeches equally tense.
\end{abstract}

Key-words: Catholic Church; Conservatism; Secularization; Human rights; Sociology of Religion. 
A côté de chaque religion se trouve une opinion politique qui, par affinité, lui est jointe.

Alexis de Tocqueville 


\section{Sumário}

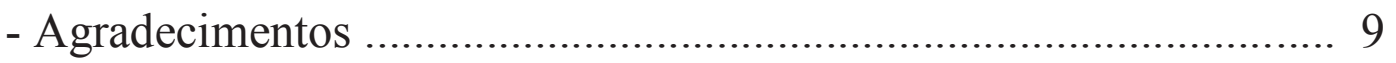

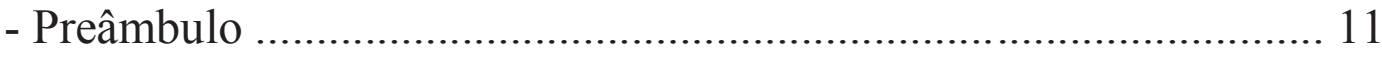

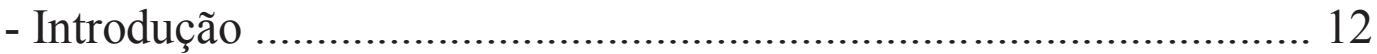

Objetos empíricos da análise ................................................................ 14

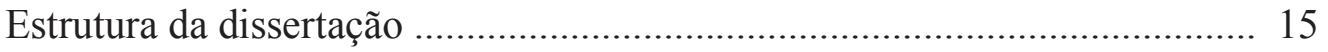

\section{- 1 . O caso do PNDH-3:}

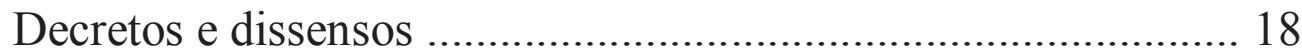

O processo de confecção do novo Programa Nacional .................................. 19

Continuidades e descontinuidades de um PNDH a outro .............................. 28

O PNDH-3 e a indignação católica ............................................................. 40

- 2. A secularização e o seu contrário:

Por uma definição de conservadorismo católico .......................... 50

"A secularização que importa em primeiro lugar" ............................................ 51

Secularização como tipo ideal ...................................................................... 62

Secularização estatal versus conservadorismo católico …………………….... 67

\section{- 3. O argumento episcopal:}

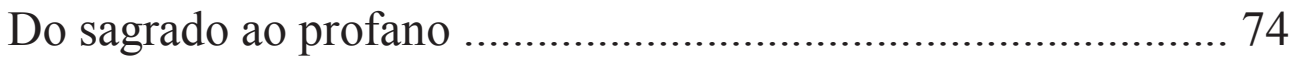

Entre a metafísica e a cultura, o crucifixo …………………………………... 75

Lei divina, lei natural e sexualidade ............................................................... 91

PNDH-3 e a reação católica (não) conservadora .......................................... 102

- Considerações finais ...................................................................... 111

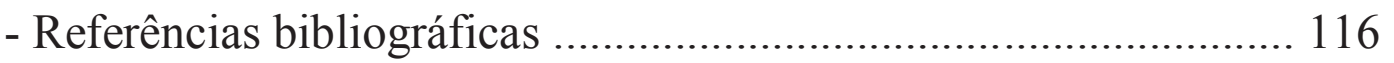




\section{Agradecimentos}

Uma vez que esta pesquisa teria sido inviável sem o amparo da Coordenação de Aperfeiçoamento de Pessoal de Nível Superior (Capes), vale começar agradecendo a essa fundação por todo o apoio.

Não há como deixar de expressar a minha gratidão a Flávio Pierucci, que tão bem me orientou - no sentido mais forte da palavra - no avanço que pede a profisssão que abraçamos. Muito obrigado. Há tanta coisa que eu deveria escrever para expressar o meu reconhecimento à sua generosidade, mas acho que eu vou parar por aqui, antes que eu comece a inundar esta dissertação em lágrimas, o que, convenhamos, não seria muito apropriado.

Agradeço também, muitíssimo, àquela que me aceitou como seu orientando no momento em que eu me via sem um norte acadêmico. Maria Helena, o cuidado demonstrado, invariavelmente, ao ouvir as minhas questões e a paciência que você teve na revisão dos capítulos da dissertação são as lembranças que eu guardo com mais carinho deste mestrado.

Meu muito obrigado aos membros da banca de qualificação, Ricardo Mariano e Maria José Rosado-Nunes, pelas leituras atentas do relatório. Espero que possam enxergar, nesta dissertação, a importância das observações que vocês fizeram. Além disso, lhe agradeço, Zeca, pela entrevista, decisiva, que pude fazer com você ainda no meu primeiro ano de Iniciação Científica. Acredite, muito do que eu aprendi naquele diálogo está presente nessa pesquisa. Também tenho que dizer obrigado ao Ricardo pela oportunidade de ser seu "estagiário" e, claro, pelas ótimas conversas após as aulas.

Da mesma forma, agradeço demais ao Reginaldo Prandi. Muito obrigado pelos banquetes, sempre sensacionais (sou muito agradecido a você também, Lena!), e por todos os passeios temáticos. Mas, principalmente, muito obrigado por ter me aberto as portas (literalmente) para que eu pudesse fazer parte do grupo de estudo de seus orientandos. Você me recebeu como se eu fosse um deles; sem querer ser piegas, mas já sendo, eu enxergo tudo isso como um ato de carinho da sua parte. No meu agradecimento ao Reginaldo, vai inclusa a minha gratidão a todos os 
integrantes do grupo. Nossos diálogos foram imensamente frutíferos e eu mal posso esperar para ver o que vocês vão falar sobre esta dissertação.

Não poderia faltar uma menção especial à Jacque e à racionalidade com relação a fins que nos conduz. Nossas conversas utilitárias - e muito belas - foram essenciais para que eu pudesse me guiar nas entranhas do universo da pósgraduação.

Muito obrigado também ao Matt, meu amigo palmeirense e californiano que ajudou na tradução do resumo desta pesquisa. E já que me lembrei do Palmeiras, agradeço à minha Sociedade Esportiva, uma das fontes de meus valores mais íntimos.

Por falar em intimidade, termino agradecendo aos meus pais, por motivos óbvios. 


\section{Preâmbulo}

Cabe expor, logo de início, uma nota metodológica que explicite aquela que é uma das preocupações primeiras deste trabalho: ter em foco que, para o sociólogo, a religião só pode ser objeto e não paradigma de pesquisa. É na atitude de vigilância negativa diante de certezas metafísicas que a sociologia se situa em sua póstradicional condição de ciência. E em tal posição, não é possível ver o campo da fé senão com olhos profanos e como coisa mundana. Nisso não reside, importante deixar claro, nenhuma impertinência iconoclasta de caráter anticlerical; trata-se da mera constatação de até onde consegue caminhar, sem sacrifícios do intelecto, a razão desencantada.

Em continuidade, se para o exercício investigativo não há absolutos de ordem sagrada, uma vez que estes não são passíveis de controle epistemológico, consequentemente o léxico a ser empreendido nesta pesquisa só pode ser outro em relação aos códigos do crente. Ou seja, a conceituação analítica há de diferir do enunciado eclesiástico. Por maior que possa ser a boa vontade cultural do estudioso de religião para com seu objeto, discursos com referência ao transcendente não são os da sociologia ou, do contrário, logo se põe a perder a vocação por excelência da atividade científica: a dessacralização deste mundo. 


\section{Introdução}

$\mathrm{Na}$ intenção de ser claro já de saída, cumpre explicitar sem demora qual o objetivo da presente pesquisa: observar a influência social do catolicismo conservador no interior da Igreja no Brasil e, para além dos limites clericais, também no que diz respeito ao âmbito jurídico-político nacional. A ideia é analisar o possível prestígio daquelas alas católicas marcadamente ortodoxas e o seu potencial de persuasão, tanto no que se refere às fileiras institucionais eclesiásticas, quanto no que concerne às esferas propriamente estatais. Em outras palavras, o foco da investigação está nas iniciativas de intervenção política de viés católicoconservador, e no modo como tais iniciativas se apresentam valorizadas (ou não) pelo poder público e pela institucionalidade católica do país.

Pretende-se tomar como ponto de partida a observação dos embates múltiplos entre representantes do poder federal e clero, desencadeados pela divulgação oficial do assim chamado PNDH-3 ( $3^{\circ}$ Programa Nacional de Direitos Humanos). Esse é o material específico da pesquisa. A escolha desse conjunto bem delimitado de acontecimentos tensos de produção de discursos não menos tensos baseia-se na constatação de uma certa singularidade histórica sua, na qual esses processos aparecem como que revestidos de características novas, para não dizer de um novo caráter, quando comparados com outras conjunturas nada remotas de relações Igreja-Estado em nosso país.

Trata-se, tudo leva a crer, de um caso no mínimo delicado para a Igreja Católica nos dias atuais, em cujo quadro ela aparece colocando-se numa situação peculiarmente embaraçosa, deslocada, fortemente prejudicial à sua imagem pública ainda altamente positiva, historicamente consolidada ao longo da segunda metade do século XX, de defensora incondicional das prerrogativas constitucionais. De portavoz tribunícia das liberdades básicas, a Igreja passa não só a manter seu frontal desacordo com grupos LGBT e militantes feministas - adversários contumazes -, mas, nesse caso, ela também se deu a ver na contracorrente de organizações em 
defesa dos direitos humanos e, não menos importante, na contramão de um governo que alcançava então um apoio popular recorde, quase $80 \%$ de aprovação nacional ${ }^{1}$.

Mas além dos controversos ocorridos, já por si altamente significativos, há outro fator que sustenta a opção empírica deste projeto: a repercussão midiática nada desprezível que o atrito do PNDH-3 provocou e, ao mesmo tempo, recebeu, objetivada fisicamente na considerável quantidade de material impresso e digital passível de investigação que foi produzida desde o início da grande polêmica. A pesquisa tem assim, a nosso juízo, sua realização justificada pelas possibilidades que foram abertas com o embate para observar, analisar e avaliar, a partir de um feixe de episódios recentes e fartamente documentados, a quantas anda o poderio político da hierarquia eclesiástica num Brasil em que se vê decrescer o monopólio católico de gestão do capital simbólico ${ }^{2}$, esvaindo-se conjuntamente muitos de seus mecanismos de legitimação social.

Uma controvérsia religiosa pública [...] funciona como um banho revelador. Ou como um sismógrafo. Detecta mudanças importantes de concepção da vida social, registra deslocamentos conceituais fundamentais imperceptivelmente em processo, molecularmente em progresso na institucionalidade mesma da sociedade (Pierucci, 1996, p. 285).

O sem-número de disputas que cercaram e constituíram o caso do PNDH-3, por mais locais que esses embates fossem em relação à vastidão do universo católico, resulta num desses dispositivos analisadores (Hervieu-Léger, 1999) por meio dos quais se apresenta possível localizar dinâmicas sociais - políticas e simbólicas - cujas implicações suplantam e muito o próprio ocorrido naquilo que diz respeito aos seus enredamentos imediatos.

\footnotetext{
${ }^{1}$ CANZIAN, Fernando. A 9 meses de sair, Lula tem aprovação recorde de 76\%. Folha de São Paulo, São Paulo, p. A4, 28 de março de 2010.

${ }^{2}$ SCHWARTSMAN, Hélio. Revolução quase silenciosa. Folha de São Paulo, São Paulo, p. A2, 30 de junho de 2013.
} 


\section{Objetos empíricos da análise}

O objeto empírico da pesquisa resumiu-se, primeiro, ao volumoso "corpus literário" de material jornalístico impresso que cobriu as controvérsias subsequentes à divulgação oficial do PNDH-3. A base documental analisada foi coletada exaustivamente na grande imprensa do eixo Rio - São Paulo, concentrando-se nos jornais de maior distribuição nacional, Folha de S. Paulo, O Estado de S. Paulo e $O$ Globo, utilizando-se principalmente de suas respectivas versões on-line. A adoção desse material fundamenta-se em sua acessibilidade, isto é, devido à grande quantidade de matérias noticiosas, artigos assinados, editoriais e cartas do leitor veiculada pelos meios em questão, possibilitando uma visão geral do cenário no qual se inseriram as tomadas de posição em jogo quando da polêmica em investigação.

Intentando, porém, focar singularmente os agentes sociais relevantes presentes na disputa, a pesquisa, continuando pautada pelo estudo de conteúdos escritos, ampliou em seguida seu campo empírico para publicações oficiais, oficiosas e também marginais, originárias especificamente daqueles que, em âmbitos diferenciados, fizeram o debate em torno do PNDH-3. Nesse sentido, valeu incluir no recorte de amostragem, publicações do clero que trataram repetida e especificamente do Programa Nacional. Para que assim pudesse ser feito, a Agência Católica de Informações (ACI) foi de grande utilidade na medida em que seu serviço de notícias propiciou o acesso a diversos dos discursos eclesiásticos desencadeados em resposta ao $3^{\circ}$ Programa. Com o mesmo propósito, e com igual proveito, esta pesquisa recorreu também à ZENIT, agência de notícias internacional focada na cobertura jornalística da Igreja Católica. Paralelamente, a análise foi também pautada pela observação de documentos próprios ao âmbito do governo federal, com destaque para aqueles emitidos, durante a polêmica, pela Secretaria Especial dos Direitos Humanos ${ }^{3}$. A totalidade dos escritos, tanto os confessionais quanto os governamentais, foi coletada e indexada num banco de dados constituído especialmente para a pesquisa. Para além dessas fontes majoritárias de investigação, coube, no momento seguinte à sistematização, o estudo de publicações de

\footnotetext{
${ }^{3}$ Pareceres da Secretaria disponíveis em: http://www.sedh.gov.br. Acessos em 30/05/2013.
} 
organizações reivindicativas LGBT e feministas, com ênfase para aquelas do Centro Feminista de Estudo e Assessoria, grupo militante que muito se expressou no caso ${ }^{4}$.

Em meio à apropriação desses conteúdos, a investigação foi também sustentada pela realização de entrevistas semiestruturadas e de tipo intensivo com indivíduos que possibilitaram o contato com outros aspectos e perspectivas envolvidas com o tema, direta e indiretamente. Entre os entrevistados, foram incluídos católicos alocados em postos religiosos de destaque, principalmente oriundos do Tribunal Eclesiástico e da Canção Nova - a maior comunidade católica nacional (Oliveira, 2009).

\section{Estrutura da dissertação}

Esta dissertação está disposta em três sessões, cada uma delas também dividida em três partes, o que totaliza a exposição da pesquisa em nove itens. No primeiro terço da análise, percorre-se descritivamente a polêmica do $3^{\circ} \mathrm{PNDH}$. Trata-se de uma empreitada que visa contar pormenorizadamente os embates que o Programa suscitou. Para relatar essa história, procura-se falar não só da versão mais recente do documento, mas também daquelas que o antecederam. O desejo é enxergar em que contexto e com que propósito se decidiu, décadas atrás, pela criação de um decreto de alcance nacional voltado à promoção de direitos humanos. Ainda nessa volta aos primórdios do Programa, serão investigadas quais emergências específicas cada PNDH queria atender. As formas como os documentos foram formulados também serão examinadas. Para fazê-lo, será questionado quem os compôs, isto é, quais secretarias e ministérios do poder público foram recrutados para delinear os eixos orientadores, diretrizes e objetivos estratégicos dos decretos. Além disso, serão percorridos os passos por meio dos quais se concretizou a interação democrática entre Estado e sociedade civil na elaboração dos Programas.

Dessa forma, em prol de melhor compreensão da indignação eclesiástica para com o PNDH-3, dá-se um passo atrás em relação às disputas advindas do decreto, para que se tenha uma perspectiva geral do episódio em análise. Ainda na ideia de

${ }^{4}$ Dados sobre a organização disponíveis em: http://www.abglt.org.br e http://www.cfemea.org.br. Acessos em 30/05/2013. 
propiciar uma vista panorâmica da cena toda, o olhar com que se desenvolve o capítulo não se circunscreverá às resistências da Igreja em relação ao $3^{\circ}$ Programa. Além dos católicos, muitos outros estratos sociais se manifestaram quando o documento foi divulgado. Essas reações, por sua vez, variaram entre cerradas oposições e efusivos aplausos ao Programa. É importante que haja noção da multiplicidade de agentes sociais e de ideários envolvidos com as problemáticas trazidas pelo $\mathrm{PNDH}-3$.

Havendo clareza quanto ao que constituiu o caso da investigação, o segundo capítulo passará para a definição do que esta pesquisa pretende dizer quando fala em “conservadorismo católico". Com as muitas prenoções que envolvem a expressão, é preciso delimitar o sentido dado ao termo. Pela atribuição de um significado bem recortado ao adjetivo católico-conservador, a intenção é utilizar a qualificação como uma categoria estritamente investigativa e de perfil sociológico. Com seus limites demarcados, o vocábulo em questão prestará um auxílio crucial para o entendimento das reações clericais ao $3^{\circ}$ Programa. Uma vez caracterizado com exatidão, o conservadorismo católico, entendido como conceito analítico, será peça-chave para o desenrolar da pesquisa.

Porém, para que a delimitação da categoria possa ser bem sucedida, será necessário, por um momento, manter distância do episódio do PNDH-3 e focalizar o já clássico paradigma da secularização. Nas ciências sociais, muitas são as disputas em torno da tese da secularização. Imiscuindo-se nessas contendas teóricas e levando em conta as problematizações ali desenvolvidas, a discussão procurará definir e manejar um conceito rigoroso de secularização, tendo em vista a formulação de um outro igualmente rigoroso de conservadorismo católico. Trata-se de um esquema que será chamado de antitético: o catolicismo é identificado como conservador na medida em que ele se contrapõe e reage à secularização. Há aí, portanto, um par de oposições, no qual a secularização suscita o conservadorismo. Desse modo, cabe compreender o que esta pesquisa entende por secularização, pois, sem esse entendimento, fica inviável destrinchar o conservadorismo católico. Se, ao falar em catolicismo conservador, há a exigência para que se faça a delimitação do que se quer expressar com o uso do termo, tendo em vista a profusão de significados do vocábulo, a mesma coisa também ocorre no caso da secularização: muitos são os 
sentidos dados à palavra no repertório acadêmico, de modo tal que é preciso estabelecer explicitamente qual é o significado que aqui se confere ao significante.

Já no último capítulo, serão analisados os discursos que lideranças clericais empregaram em resposta ao PNDH-3. Para isso, remeter-se-á à descrição do episódio do Programa Nacional e às definições conceituais concluídas nas duas primeiras sessões. Serão tomados pronunciamentos escritos por bispos da Igreja como pontos principais de investigação. Haja vista a posição de alto prestígio ocupada pelo episcopado, na estrutura católica, ficou decidido que o foco da terceira sessão da pesquisa incidirá sobre os muitos enunciados redigidos por bispos ao longo do caso do $3^{\circ} \mathrm{PNDH}$. Serão examinadas as linhas argumentativas utilizadas pelos membros da alta hierarquia clerical durante a polêmica, de modo que se possa avaliar, pelas tomadas de posição dos líderes da Igreja, a situação do ideário conservador na instituição eclesiástica. Nesse exame das falas sacerdotais, será realizado um exercício comparativo entre as manifestações contemporâneas do clero brasileiro e os discursos clericais da primeira metade do século XX. Pela verificação das continuidades e dos deslocamentos dos argumentos religiosos no intervalo desses dois períodos, será possível interrogar a quantas anda o prestígio do conservadorismo católico no que concerne ao âmbito do poder público. 


\section{O caso do PNDH-3: Decretos e dissensos}

Dado que o objetivo desta investigação está integralmente fundado na análise dos conflitos suscitados pela publicação do PNDH-3, com foco especificamente na atuação da Igreja Católica durante a polêmica, cumpre então que se esclareça de modo satisfatório como se deram as muitas ocorrências, voltas e reviravoltas que caracterizaram o episódio. Porém, centrar o olhar já de pronto nas manifestações eclesiásticas faria perder de vista a conjuntura que serviu de base para o desenrolar dos acontecimentos. É preciso ter clareza sobre o que é o $3^{\circ}$ Programa Nacional, e como ele foi constituído, para daí sim ser possível abarcar as razões da insatisfação clerical para com aqueles que o compuseram. O que estava em jogo quando foi decidida a criação de um novo Programa de Direitos, quais prioridades o decreto procurava atender, de que maneira e por quem o documento foi formulado - tais informações precedem, cronológica e analiticamente, a ação católica que é aqui objeto de pesquisa. Além disso, cabe lembrar que religiosos não são os únicos agentes sociais relevantes na controvérsia que se seguiu. Membros de outros estratos estiveram igualmente descontentes com o PNDH-3 e agiram, lado a lado com a Igreja, para reparar as razões de seus incômodos. Houve ainda inúmeros sujeitos que saudaram o decreto como uma ótima e necessária novidade. Como se vê, muitas foram as personagens que figuraram na trama. Igualmente, muitos foram os embates e de diversas naturezas. As disputas clericais deram-se em paralelo, várias vezes imiscuídas em lutas que escapavam da alçada do catolicismo, com indivíduos que nada tinham com o universo eclesiástico. A rixa que está no centro desta pesquisa envolve figuras e ideários religiosos, mas ocorre no interior de uma polêmica maior, na qual facções e valores dos mais variados perfis agiram e reagiram em embates de força. Uma observação do comportamento da Igreja na contenda exige que se reconheça razoavelmente a existência de outros campos de ação igualmente ali presentes. Em resumo, se a intenção for depreender os sentidos das condutas católicas na ocasião, que primeiro se obtenha uma visão panorâmica do "plano da peça" e do desenvolvimento geral do roteiro que perpassou o caso.

Tendo em vista, portanto, a relevância de apresentar, de início, uma perspectiva mais ampla do episódio em análise, esta sessão foi organizada a partir de 
uma divisão em três partes principais. No item de abertura, é exposto como se deu a elaboração do $3^{\circ}$ Programa, contemplando principalmente as conferências várias que pontuaram o processo de feitura do documento. Centra-se o olhar nas inquietações que ao final marcariam o decreto, mas que estavam presentes desde seus primeiros esboços, ainda que de maneira espaçada e não enfática. Desse modo, é possível espreitar as problemáticas para as quais o programa foi pensado em resposta. Após examinar quais questões foram valorizadas na formulação do PNDH-3, parte-se para uma observação comparada dele em relação aos seus antecessores. O segundo item tenta entender por qual razão o último PNDH despertou tanta repercussão enquanto apenas tímidas notas passageiras acompanharam os dois primeiros. Com essa interrogação em mente, procura-se apresentar os programas pioneiros e mostrar as linearidades e mudanças existentes entre os PNDHs. Também nesse item, são mostradas medidas do decreto atualmente vigente que, por diferentes razões, suscitaram enormes reações públicas. Tratando ainda das diretrizes controversas do PNDH-3, são examinadas finalmente, no último item, aquelas pautas do programa que foram causa de escândalo para partes notáveis da Igreja Católica. Em seguida às pautas, vieram as enérgicas repercussões eclesiásticas negativas, as quais foram sucedidas por tréplicas igualmente vigorosas provindas de apoiadores do PNDH-3. Essa dinâmica intensa, que perdurou ao longo do caso em análise, será acompanhada no terceiro item até o momento em que a discórdia atingiu seu estopim, isto é, até as eleições presidenciais de 2010.

\section{O processo de confecção do novo Programa Nacional}

Em dezembro de 2009, o PNDH-3 foi lançado pelo governo federal ${ }^{1}$. O documento, contendo mais de quinhentas orientações governamentais, foi publicado no Diário Oficial da União, após passar pelas assinaturas do então presidente da República e de vinte e oito ministros ou seus representantes ${ }^{2}$. Antes de sua divulgação, o programa foi ainda submetido à vistoria jurídica da Casa Civil. Sua

\footnotetext{
${ }^{1}$ Decreto número 7.037, de 21 de dezembro de 2009. Disponível em: http://www010.dataprev.gov.br/sislex/paginas/23/2009/7037.htm. Acesso em 30/05/2013.

${ }^{2}$ SALOMON, Marta. Críticos tiveram quatro meses para mudar projeto, diz Vannuchi. Folha de São Paulo, São Paulo, p. A7, 9 de janeiro de 2010.
} 
elaboração coincidiu com os sessenta anos da Declaração Universal dos Direitos Humanos e resultou de um processo democrático que mobilizou, ao longo de 2008, a realização de dezenas de conferências locais. Esses encontros regionais, 137 ao todo, contaram com a presença de milhares de pessoas, reunindo, entre outros, populações ribeirinhas, comunidades de terreiro, ambientalistas, sem-terra, sem-teto, militantes de movimentos de mulheres, ativistas da diversidade sexual, indígenas, ciganos, militantes dos direitos da criança e do adolescente, pessoas com deficiência, negros e quilombolas ${ }^{3}$. Em tais conferências, esteve em pauta a gestação dos fundamentos necessários à formulação de uma política nacional de direitos humanos como política de Estado.

Tendo os encontros locais como alicerce, entre os dias $1^{\circ}$ de maio e 15 de setembro de 2008, foram realizadas conferências estaduais e distrital nas 27 unidades da federação. Todas essas assembleias - locais, estaduais e distrital -, foram organizadas a partir do texto-base enviado junto à convocação da $11^{\mathrm{a}}$ Conferência Nacional de Direitos Humanos $\left(11^{\mathrm{a}} \mathrm{CNDH}\right)^{4}$. Estabelecida por decreto presidencial, a $11^{\mathrm{a}} \mathrm{CNDH}$ envolveu também milhares de participantes e contou com o comparecimento de representantes governamentais (membros do Ministério Público, da Defensoria Pública e dos Poderes Executivo, Legislativo e Judiciário) na proporção de $40 \%$ do total, para $60 \%$ da sociedade civil, também presente ${ }^{5}$ : uma deliberada tentativa de interação entre Estado e sociedade civil. A tarefa de propiciar essa reciprocidade entre esferas governamental e societal foi facilitada pela formação de uma comissão tripartite na qual estiveram representados poder público e movimentos sociais. Tal composição estatal/civil deu-se a partir da articulação entre a Secretaria Especial dos Direitos Humanos da Presidência da República (SEDH/PR), a Comissão de Direitos Humanos e Minorias da Câmara dos Deputados (CDHM) e o Fórum de Entidades Nacionais de Direitos Humanos (FENDH). Esses três âmbitos formaram a Coordenação Executiva do Grupo de Trabalho da $11^{\mathrm{a}}$ CNDH. Ainda em continuidade com o ideal de intercâmbio entre instituições

\footnotetext{
3 1ํ Relatório nacional da República Federativa do Brasil sobre o cumprimento das disposições da Convenção sobre os Direitos das Pessoas com Deficiência, parágrafo 37.

${ }^{4} \mathrm{O}$ texto-base que convocou a 11a CNDH está disponível em:

http://www.dhnet.org.br/dados/conferencias/nacionais/texto_base_11_conf_dh_2008.pdf. Acesso em 30/05/2013.

${ }^{5}$ Dados apresentados pelo Centro Feminista de Estudos e Assessoria e confirmados pela Secretaria Especial dos Direitos Humanos da Presidência da República.
} 
estatais e coletividades civis organizadas, o Grupo de Trabalho propriamente dito foi constituído em igual proporção por representantes do poder público e da sociedade inclusiva. Esses representantes foram indicados pela SEDH/PR, pela CDHM e pelo FENDH. Além disso, os seguintes órgãos foram aceitos como auxiliares do Grupo de Trabalho: a Procuradoria Federal dos Direitos do Cidadão, do Ministério Público Federal; o Conselho Nacional de Justiça; a Defensoria Pública da União; a Comissão de Participação Legislativa da Câmara dos Deputados e a Ordem dos Advogados do Brasil $^{6}$.

Citado e referenciado acima, cabe voltar ao texto-base que serviu de sustentáculo para os encontros democráticos prévios ao PNDH-3. O documento catalisador e organizador das conferências tomou como parâmetro uma inovadora compreensão de direitos humanos, que fora relativamente desenvolvida e acumulada nas dez edições anteriores da CNDH. Sucintamente, trata-se da compreensão que julga os direitos fundamentais indivisíveis, logo, interdependentes. Daí a opção de utilizar no texto-base, como impulso às discussões que se seguiriam, um conjunto de eixos orientadores, e não temas específicos. Os eixos orientadores foram nomeados e dispostos na seguinte ordem:

A) Universalizar direitos em um contexto de desigualdades

B) Violência, segurança pública e acesso à justiça

C) Pacto federativo e responsabilidades dos três Poderes, do Ministério Público e da Defensoria Pública

D) Educação e cultura em direitos humanos

E) Interação democrática entre Estado e sociedade civil

F) Desenvolvimento e direitos humanos

É interessante analisar o que foi esboçado como aspiração para cada um desses eixos. Trata-se do documento inaugurador do processo que, mais tarde, resultaria no PNDH-3, de modo que se faz proveitoso um melhor entendimento de

\footnotetext{
${ }^{6}$ Para mais informações sobre a constituição do Grupo de Trabalho da 11 $\mathrm{CNDH}$, consultar a respeito em: http://portal.mj.gov.br/sedh/pndh3/pndh3.pdf, página 16. Acesso em 30/05/2013.
} 
suas pautas. Esmiuçando o texto-base, procura-se abarcar minimamente o ethos no interior do qual o Programa Nacional foi formulado em seu prenúncio. Além de captar o "clima geral" que cercou o projeto do PNDH-3, retomar o texto-base também possibilita a caracterização de como o decreto ficou formatado. Tirante o item "C" acima, todos os outros permaneceram no PNDH-3 e o estruturaram, servindo como eixos sobre os quais o programa se ordena. Além do mais, a redação de cada item do texto-base finaliza com uma série de interrogações, imbricadas ao texto do PNDH-3 que estava por vir. Esse documento foi constituído como respostas programáticas às questões pragmáticas colocadas no texto-base. Consequentemente, já que sobram razões para se aproximar do texto, resta fazê-lo de uma vez.

O item "A" pretendia lidar com as possibilidades de efetivação de uma política, no Brasil, voltada prioritariamente aos direitos humanos:

No Brasil, importantes avanços registrados desde a redemocratização ainda convivem com a persistência de graves violações de direitos. Esses fatos demonstram que, não obstante as inúmeras conquistas que expandiram a proteção dos direitos humanos, exigem-se, ainda, muitas outras iniciativas e mudanças no âmbito dos poderes públicos e também na esfera da vida social para atingir o desejável estágio de sua universalização e consolidação ${ }^{7}$.

O estabelecimento dessa política de direitos humanos, porém, não poderia deixar de lado o fato de que qualquer estratégia nessa direção teria de levar em conta a condição socioeconômica circundante: nesse caso, a condição de um dos países mais desiguais do mundo. Imbricadas à má distribuição de renda, erguem-se desigualdades preocupantes no que diz respeito à exclusão racial. $\mathrm{O}$ texto-base da $11^{\text {a }} \mathrm{CNDH}$, a partir de informações colhidas pelo Instituto de Pesquisa Econômica Aplicada (IPEA), procura mostrar a posição marginalizada em que se encontra a

\footnotetext{
${ }^{7}$ Página 16 do texto-base referente à 11a $\mathrm{CNDH}$.
} 
população negra nacional - dois terços da população pobre é negra; no mercado de trabalho, negros têm renda, em média, duas vezes menor do que a auferida por brancos; a taxa de homicídio de negros é cerca de duas vezes superior à observada para brancos. Contudo, a complexa estrutura de desigualdade brasileira não se pauta somente por marcadores sociais de raça. O texto-base também olha para discriminações de gênero que se fazem persistentes. Utilizando mais de uma vez os dados do IPEA, o texto constata a existência de um "sexismo que permeia todas as relações sociais [...]. Reconhece-se assim que as mulheres ainda enfrentam dificuldades quanto ao acesso pleno a sua cidadania”. Por fim, há desigualdades perpetuadas por critérios territoriais. O meio urbano - marcado por periferias sem acesso a direitos básicos - e o meio rural - com sua concentração fundiária gritante - propiciam uma relação de determinação entre território e possibilidade de acesso a serviços públicos.

Com essas constatações em mãos, o texto-base termina seu primeiro item com várias interrogações, que podem ser resumidas em duas: "Como a desigualdade de renda, racial, de gênero, entre outras, afeta a efetivação dos direitos humanos no Brasil e o alcance das políticas universais? Como o PNDH deve responder a isso?".

Feita a exposição sobre a posição desigual do negro e da mulher, no primeiro eixo, o segundo, já de início, fala a respeito da violência por que passam esses atores sociais. O eixo trata também de trabalho escravo, da violência sexual contra crianças e adolescentes, da criminalização da pobreza, da intimidação sofrida por lideranças populares e da "violência institucionalizada" agenciada por entes públicos e privados (promovida por meio de execuções sumárias e torturas).

As arraigadas estruturas de poder e subordinação presentes na sociedade brasileira têm sido historicamente marcadas pela violência, gerando um círculo vicioso de insegurança, desrespeito, impunidade e medo ${ }^{8}$.

\footnotetext{
${ }^{8}$ Página 18 do texto-base referente à 11a $\mathrm{CNDH}$.
} 
Ainda que avanços tenham sido alcançados - cita-se, por exemplo, a Lei Maria da Penha ${ }^{9}$, tida como um passo determinante na regulação legal da violência doméstica -, a violência ameaça a efetivação dos direitos humanos no país. A concepção que perpassa esse segundo item do texto-base é a de que o acesso à justiça e à segurança pública são direitos fundamentais. $O$ texto aconselha que a $11^{\mathrm{a}}$ CNDH abra caminho para discussões a respeito da reforma do Poder Judiciário. No ritmo a ser exibido para tal reforma, a Conferência Nacional de Direitos deve ter em foco a celeridade e a transparência na atuação do Ministério Público e das defensorias Públicas.

Para a articulação do debate que resultaria no PNDH-3, o eixo finaliza questionando quais devem ser as prioridades do $3^{\circ}$ Programa Nacional, num ambiente em que se observam lacunas do sistema de segurança pública, desfalques que entravam a efetivação de direitos. Em paralelo, o texto aguarda que sejam feitas propostas concretas para uma maior agilidade e qualidade na administração da justiça.

O eixo sobre Pacto Federativo, responsabilidades dos três Poderes, do Ministério Público e da Defensoria Pública, o terceiro do texto-base, não consta no PNDH-3. O seu conceito, porém, permanece crucial ao $3^{\circ}$ Programa, que tem como uma de suas principais características a indicação de quem são os responsáveis institucionais pela execução de cada ação programática do decreto. $\mathrm{O}$ eixo parte da percepção de que há ausência de uma legislação que regularize o modo como deve ocorrer o cumprimento das decisões subscritas por entidades internacionais de proteção aos direitos humanos das quais o Brasil é signatário. Já no âmbito das deliberações exclusivamente nacionais sobre direitos, quase inexiste a fixação formal de quais são os deveres vinculados à União, aos Estados e aos municípios. $\mathrm{Na}$ proteção e efetivação de políticas para os direitos fundamentais, falta também maior contato dos trabalhos do Poder Judiciário, da Defensoria Pública e do Ministério Público.

Vários desafios devem ser enfrentados: a articulação de uma política pública de Estado que trate os direitos humanos de

\footnotetext{
${ }^{9}$ Lei número $11.340 / 06$.
} 
forma integrada; a definição de responsabilidades compartilhadas entre a União, os Estados e os Municípios na execução de políticas públicas; a integração do Poder Judiciário, do Ministério Público e da Defensoria Pública dentro de um sistema de respeito, proteção e efetivação dos direitos humanos ${ }^{10}$.

$\mathrm{O}$ eixo $\mathrm{C}$ questiona sobre o que caberá à União e o que estará aos cuidados dos entes do pacto federativo (Estados e Municípios) quanto à efetivação do PNDH3. Passando o foco para os três Poderes do Estado, o texto-base coloca a interrogação sobre quais serão os papéis do Executivo, do Legislativo e do Judiciário para a implementação do novo Programa Nacional.

O quarto item do documento, por sua vez, confere importância à construção das bases daquela que é chamada de "cultura de direitos humanos" ". Trata-se do empoderamento por parte dos cidadãos para que se vejam enquanto sujeitos dignos de ter direitos. Porém, para que uma percepção desse calibre perdure cotidianamente, torna-se urgente que haja uma educação de direitos humanos:

Informar, e mais ainda, educar em direitos humanos significa criar as bases para construção de uma cultura [...] em que as pessoas se reconheçam como sujeitos de direitos e participem ativamente deste processo.

Nessa aspiração está, possivelmente, o ponto mais interessante desse eixo: nas reflexões sobre cultura de direitos, é delineada a ideia de que a comunicação é um bem fundamental. Ou seja, o acesso à informação deixa de ser visto como mero item de consumo não essencial. Esse reconhecimento da comunicação como um direito humano desembocará num dos pontos controversos do PNDH-3: o que ficou

\footnotetext{
${ }^{10}$ Página 19 do texto-base referente à 11 a $\mathrm{CNDH}$.

${ }^{11}$ Página 20 do texto-base referente à 11 a $\mathrm{CNDH}$.
} 
conhecido como "controle social da mídia". Mais adiante, neste mesmo texto, esse dissenso será observado.

Assim como no eixo anterior, também aqui as interpelações que concluem o item remetem ao pacto federativo. Para efeito de concisão, as questões do item " $D$ " podem ser aglutinadas em apenas uma: quais políticas públicas das esferas federal, estadual e municipal devem ser manejadas para um maior acesso à cultura e educação em direitos humanos? Essa questão foi colocada pelo texto-base à $11^{\mathrm{a}}$ $\mathrm{CNDH}$, que procurou respondê-la por meio do PNDH-3.

Nesta exposição, já foi ressaltado o valor conferido às interações entre Estado e sociedade civil durante todo o processo de feitura do PNDH-3. O penúltimo eixo do texto-base focaliza exatamente a necessidade de a democracia contar com uma sociedade civil que não se amolde pura e simplesmente aos impulsos do Estado. Nesse sentido, os movimentos sociais são lembrados como indispensáveis para a democracia. Seu caráter imprescindível está presente na medida em que cumprem a função, prevista pelas instituições democráticas, de fiscalizar e cobrar o poder público. Além disso, cabe à dinâmica democrática a guarda dos direitos humanos, os quais devem ser observados a partir de esforços comuns da ordem estatal e do estrato civil. O texto-base toca na urgência de criar novas ferramentas para que a esfera civil possa acompanhar o andamento das ações do poder público em prol dos direitos humanos.:

É necessário integrar e aprimorar os espaços de participação existentes, bem como criar novos espaços e mecanismos institucionais de construção e monitoramento das políticas públicas de direitos humanos no país. [...] A interação democrática entre Estado e sociedade civil pressupõe também a transparência e a disponibilização de informações públicas necessárias para o exercício do controle social das políticas públicas ${ }^{12}$.

\footnotetext{
${ }^{12}$ Página 20 do texto-base referente à 11 1 CNDH.
} 
Muitas indagações são feitas, ainda no mesmo eixo, em seguida à discussão sobre a importância das interações entre sociedade civil e Estado. Uma delas destaca-se pela relevância: "Como articular [...] a complexa estrutura de participação popular nas políticas públicas, por meio de diversos conselhos e conferências setoriais, no monitoramento [...] do PNDH"?

Por fim, o último item do texto que serviu de sustentáculo para a construção do $3^{\circ}$ Programa procurava mostrar que o desenvolvimento econômico poderia ser um entrave aos direitos humanos ${ }^{13}$. Entretanto, o mesmo desenvolvimento estaria apto a funcionar como um catalisador de direitos. Focando os riscos, o texto-base delineia dois estorvos principais para o crescimento econômico: a concentração de renda e o passivo ambiental insustentável. Para ambos os riscos, são sugeridas políticas de longa duração que maximizem o impacto positivo que o desenvolvimento pode ter para a realização dos DHESCAs (direitos humanos, econômicos, sociais, culturais e ambientais). Uma política econômica voltada aos direitos humanos implicaria, por exemplo, um maior controle social sobre a ação de grandes empresas transnacionais, as quais são vistas no texto-base como atores que recorrentemente violam direitos humanos. O foco principal do eixo está nas violações aos direitos humanos em meios rurais. Essa preocupação se refletirá no PNDH-3 e resultará em grandes polêmicas com agente do agronegócio.

Esse debate põe em questão os investimentos em infraestrutura e modelos de desenvolvimento econômico na área rural baseados exclusivamente no agronegócio, na medida em que esses podem violar direitos de pequenos e médios agricultores, bem como de populações tradicionais.

A pergunta principal do último eixo relaciona-se diretamente com esse ponto: como responsabilizar corporações que infringem direitos fundamentais?

\footnotetext{
${ }^{13}$ Página 21 do texto-base referente à 11 ạ $\mathrm{CNDH}$.
} 
O que era intencionado com a ordenação desses itens era que eles fossem efetivados como orientadores de políticas públicas direcionadas à defesa e à promoção dos direitos humanos. Para a concretização desse ideal, as conferências deveriam propor medidas concretas em suas pautas. Desse modo, o relatório final da $11^{\mathrm{a}} \mathrm{CNDH}$ apresentou, para os eixos orientadores, propostas de ações que se espaçaram ao longo de 36 diretrizes, repartidas em 702 resoluções e 99 moções. Esse material, por sua vez, resultou nas 25 diretrizes, 82 objetivos estratégicos e 521 ações programáticas que formam o PNDH-3. Durante a $11^{\mathrm{a}} \mathrm{CNDH}$, mais um item foi acrescido como eixo orientador do Programa Nacional: o eixo denominado $O$ direito à memória e à verdade. A inclusão dessa pauta foi consequência de demandas por parte da sociedade civil surgidas no decorrer das conferências estaduais, distrital e nacionais. Procurava-se, com o novo eixo, instituir uma política pública que propiciasse maior acesso a informações sobre possíveis atentados aos direitos humanos ocorridos durante o período militar brasileiro.

Ainda focalizando as deliberações populares que, ao final, desaguaram no PNDH-3, não há como deixar de lembrar que, desde 2003, foram realizadas mais de cinquenta conferências nacionais temáticas que tiveram, como pautas específicas, matérias dos seguintes perfis: habitação, direitos da mulher, segurança alimentar, meio ambiente, igualdade racial, juventude, pessoas com deficiência e idosos. A realização dessas conferências promoveu debates públicos diretamente incorporados ao PNDH-3. Há de se destacar a $1^{\text {a }}$ Conferência Nacional de Gays, Lésbicas, Bissexuais, Travestis e Transexuais, encontro histórico que muito contribuiu com o documento em questão ${ }^{14}$.

\section{Continuidades e descontinuidades de um PNDH a outro}

Ainda que pautado por todos esses sistemáticos procedimentos de construção democrática, o PNDH-3, logo que lançado, recebeu as alcunhas de "constituinte

\footnotetext{
${ }^{14}$ Ver a respeito em:

http://portal.mj.gov.br/sedh/pndh3/pndh3.pdf, página 12. Acesso em 30/05/2013.
} 
golpista"15, "roteiro para o autoritarismo"16, "constituição de viés ideológico ditatorial venezuelano"17, entre outras muitas caracterizações de mesmo calibre provindas de setores da opinião pública. Tais reações em alto e bom som, por sua vez, contrastam nitidamente com as repercussões silenciosas apresentadas quando da publicação das edições anteriores do PNDH (Adorno, 2010). A ideia dos Programas Nacionais foi esboçada na Conferência Mundial dos Direitos Humanos (1993), realizada em Viena. Ali, foi sugerido aos países presentes que elaborassem documentos governamentais com o propósito de sistematizar a promoção e proteção dos direitos universais. Em consonância com essa recomendação, o PNDH-1 foi apresentado, em 1996, ${ }^{18}$ de modo pioneiro nas Américas e como um dos primeiros no mundo, seguindo os exemplos de Austrália, África do Sul e Filipinas.

O primeiro Programa Nacional contava com 228 propostas e surgiu com o lema "direitos humanos para todos". As propostas e o lema voltavam a atenção para os direitos das sociedades indígenas, dos negros, dos emigrantes, dos imigrantes, das crianças e adolescentes e dos indivíduos portadores de deficiência. Da mesma forma, o decreto direcionou o olhar para a ratificação de convenções internacionais em que havia representação do poder público brasileiro. O Programa calou-se no relativo ao direito à livre orientação sexual e às identidades de gênero (ibid, p. 11). Também silenciou sobre a problemática do aborto. Além disso, o documento não tocou na investigação sobre mortos e desaparecidos do regime militar (Oliveira, 2013, p. 31). Todas essas são questões urgentes e já pulsantes em relação às quais o primeiro decreto passou ao largo. Apesar dessas carências, e mesmo apresentando uma visão por vezes vaga e abstrata dos direitos humanos (ibid, p. 30), ainda assim, o PNDH-1 resultou em medidas de grande alcance. Uma das intenções declaradas do Programa era medir forças com as arbitrariedades dos encarregados de fazer cumprir as leis. Nesse sentido, não foi à toa que os principais ganhos foram conseguidos no campo

\footnotetext{
${ }^{15}$ AZEVEDO, Reinaldo. Ainda o golpe dos direitos humanos: Desconstruindo outra mentira. Disponível em: http://veja.abril.com.br/blog/reinaldo/geral/ainda-o-golpe-dos-direitos-humanos-desconstruindooutra-mentira. Data da publicação: 10/01/2010. Acesso em 03/08/2013.

${ }^{16}$ Editorial de O Estado de S Paulo. Disponível em: http://exame.abril.com.br/rede-deblogs/instituto-millenium/2010/01/11/roteiro-para-o-autoritarismo. Data da publicação: 10/01/2010. Acesso em 03/08/2013.

${ }^{17}$ MARTINS, Ives Gandra Silva. Guerrilha e redemocratização. Disponível em: http://www1.folha.uol.com.br/fsp/opiniao/fz2201201008.htm. Data da publicação: 22/01/2010. Acesso em 04/08/2013.

${ }^{18}$ Decreto número 1.904, de 13 de maio de 1996. Disponível em: http://portal.mj.gov.br/sedh/pndh/pndh1.pdf. Acesso em 01/08/2013.
} 
da segurança pública: criminalização do porte ilegal de armas e formação do Sistema Nacional de Armas; regularização da escuta telefônica (regulamentando o inciso XII do artigo $5^{\circ}$ da Constituição); aprovação do Estatuto dos Refugiados; formatação da Secretaria Nacional de Direitos Humanos; no caso de policiais militares acusados de crimes dolosos contra a vida, a competência para julgamento foi transferida da Justiça Militar para a Comum; houve também, finalmente, a tipificação do que constitui crime de tortura, com a fixação de penas (severas) (Adorno, 2010, p. 11). Outra consequência de grande repercussão advinda do primeiro PNDH foi o estabelecimento do registro de nascimento gratuito (ibid, p. 12), título que era ausente para número significativo de brasileiros e que garante nacionalidade e cidadania.

Seis anos decorridos da edição do PNDH inicial, foi publicado o PNDH-2, ainda no governo de Fernando Henrique Cardoso. ${ }^{19}$ No contraste entre os dois documentos, o que chama primeiro o olhar para o segundo decreto é o número de proposições ali situadas para a efetivação dos direitos humanos: 518 medidas, mais que o dobro em relação ao PNDH-1. Essa diferença expressiva reflete o aumento considerável do escopo de direitos que o PNDH-2 reconhece como merecedores de proteção e promoção pelo Estado brasileiro (Oliveira, 2013, p. 31). O documento então falava em identidade de gênero e reconhecia o direito de livre orientação sexual. Além disso, dava um maior destaque para a violência doméstica e para o combate ao trabalho infantil e forçado. O Programa também responde às lutas por maior inclusão social para cidadãos que necessitam de cuidados especiais, as assim nomeadas "pessoas portadoras de deficiência". Comparado ao primeiro decreto, o PNDH-2 expõe muito mais detalhadamente como deve ocorrer o resguardo dos direitos à saúde, à educação, à moradia, ao trabalho, à assistência e previdência social, à alimentação e ao lazer. De igual modo, os dependentes químicos e portadores de HIV foram contemplados pelo segundo documento. É dada também atenção aos direitos de acesso à terra. Cabe destacar, acima de tudo, o enfoque do PNDH-2 no que diz respeito aos afrodescendentes. Pela primeira vez em sua história, o Estado brasileiro reconheceu formalmente a existência de racismo no país e apontou para a possibilidade de promoção de políticas compensatórias (Adorno,

\footnotetext{
${ }^{19}$ Decreto número 4.229, de 13 de maio de 2002. Disponível em: http://portal.mj.gov.br/sedh/pndh/pndhll/Texto\%20Integral\%20PNDH\%20II.pdf. Acesso em 01/08/2013.
} 
2010, p. 11). Essas medidas visavam contrabalancear perdas econômicas e sociais historicamente acumuladas, decorrentes da discriminação racial. No interior das iniciativas de ação afirmativa, encontravam-se projetos para a ampliação do acesso de afrodescendentes à justiça, o incentivo à participação de negros em propagandas governamentais e em campanhas publicitárias em geral, propostas de revisão dos livros didáticos com o objetivo de recuperar a contribuição da cultura e de personagens negras para a formação da identidade nacional, além de outras políticas de preservação da memória afro-brasileira, como o registro de comunidades quilombolas ainda existentes (ibid, p. 12).

Desde a Declaração da Conferência Mundial de Viena, que recomendou a cada país participante do encontro que levasse a sério a oportunidade de elaborar um plano de ação nacional voltado aos direitos humanos, já ali, a ideia sempre foi que, mais do que um plano governamental, as medidas para os direitos deveriam ser políticas de Estado. Foi o que todos os três PNDHs se dispuseram a fazer. Os programas procuram superar possíveis desarticulações entre as instâncias constitutivas do aparato estatal e contam, ao menos em tese, com a possibilidade de diálogo entre os Poderes. Estava suposto que o Executivo, o Legislativo e o Judiciário poderiam trabalhar juntos, o mesmo valendo para os diferentes ministérios e para os governos municipais, estaduais e federal. Trata-se, em suma, de situar os direitos humanos como um compromisso da nação, não somente de um governo (Oliveira, 2013, p. 32). Logo, também era presumido que predecessores e sucessores de um determinado cargo fossem capazes de trabalhar coordenadamente, mesmo que pertencendo a filiações opostas. Os programas, portanto, foram idealizados para serem lidos e colocados em prática como medidas suprapartidárias:

\section{[...] embora a revisão do Programa Nacional esteja sendo} apresentada à sociedade brasileira a pouco mais de um ano da posse do novo governo, os compromissos expressos no texto quanto à promoção e proteção dos direitos humanos transcendem a atual administração e se projetam no tempo, 
independentemente da orientação política das futuras gestões (Decreto $\mathrm{n}^{\mathrm{o}}$ 4.229, de 13 de maio de 2002, p. 3).

Porém, mesmo que os PNDHs apresentem um ensaio de articulação de todos os poderes republicanos, ainda assim essas tentativas políticas são cautelosas em relação ao resguardo do pacto federativo. Mais especificamente, há precaução manifesta em não infringir a Constituição, que vigia e garante a autonomia das entidades territoriais dotadas de governo próprio, razão pela qual os documentos enfatizam o caráter de "recomendação" sempre que as medidas exigem, para sua execução, o envolvimento conjunto das três esferas administrativas da nação (União, Estados e Municípios). O mesmo tom de aconselhamento - e de cuidado para com a Constituição - é enfatizado nos programas quando seus itens prefiguram ações junto à Defensoria Pública e ao Ministério Público. Semelhante juízo pode ser visto também quando compromissos conjuntos dos três Poderes são requisitados. Logo, os decretos em questão não têm a pretensão ou a capacidade, por si só, de mudar leis. São decretos do Presidente da República, ou seja, os PNDHs são compostos de diretrizes direcionadas à administração pública federal, sem interferência em esferas legislativas ou judiciárias. No que diz respeito a alterações de medidas legais, o que existe são propostas de mudança, as quais ainda precisariam chegar ao Congresso Nacional para serem discutidas, revisadas, aprovadas ou contestadas.

Além dessa afinidade jurídica, há também uma "afinidade de espíritos" entre os PNDHs e a Constituição Brasileira. É destacável que os direitos humanos se incluem como um dos núcleos duros da Carta de 1988. Não por acaso apelidada por Ulisses Guimarães de "Constituição Cidadã", a Lei Maior tem nos direitos humanos a sua espinha dorsal e é exatamente ao redor desse núcleo que as responsabilidades do Estado são definidas. Direitos individuais e coletivos são ali listados paralelamente à caracterização de cidadania, e são indicadas em relação a eles políticas públicas, ainda que genéricas, que garantam sua efetivação. Daí ser compreensível que Cattoni de Oliveira, especialista em Direito Constitucional, enxergue os PNDHs como passos importantes dentro do processo nacional de consolidação democrática (Cf. Cattoni de Oliveira; Gomes, 2011). Cattoni demonstra a relevância desses programas para o fortalecimento da democracia a partir de dois passos sucessivos: primeiro, há a confirmação bastante evidente de 
que o projeto constitucional pós-período militar reinaugura o Estado democrático de direito; em seguida, o jurista localiza nos PNDHs um "esforço de compreensão do próprio projeto constitucional": "Se é verdade que a Constituição de 1988 assegura a liberdade e a igualdade, o que deve significar a concretização desses princípios no contexto da sociedade brasileira?" (ibid, p. 99). Cattoni enxerga nessa interrogação a dúvida por excelência que move os decretos.

Analogamente, Sérgio Adorno também vê os Programas Nacionais como que imbricados à reabertura política e ao texto constitucional:

Os Programas Nacionais de Direitos [...] resultam de uma história recente de consolidação das instituições democráticas na sociedade brasileira. Têm por referência a Constituição de 1988, conhecida como "Constituição cidadã". O PNDH-3 não é, sob essa perspectiva, uma iniciativa absolutamente nova, tampouco um tresloucado gesto de militantes políticos da velha esquerda [...]. Ao sancionar o Decreto 7.037, de 21 de dezembro de 2010, o presidente Lula agiu como chefe de Estado, tal como seu predecessor o fizera, representando todos os poderes constitucionais. Era o que se esperaria de seu papel constitucional (Adorno, 2010, p. 10).

Mesmo havendo essa continuidade entre os programas no que diz respeito ao apreço pela ordem democrática e pela constituição que a sustenta, ainda assim, a senadora Kátia Abreu (DEM-TO) nomeia o PNDH-3 de "plataforma totalitária”, o que é curioso na medida em que a mesma senadora classifica o processo de efetivação do PNDH-1 como "competente [...] implantação, em 1996, de um consistente programa nacional de direitos humanos". O PNDH-2, por sua vez, é igualmente tido em alta estima por Abreu: "o segundo programa deu continuidade aos avanços, reconhecidos internacionalmente" ${ }^{20}$. Já Reinaldo Azevedo, jornalista da

${ }^{20}$ ABREU, Kátia. Direitos humanos ou gato por lebre? Folha de São Paulo, São Paulo, p. A3, 12 de janeiro de 2010. 
revista Veja e colunista da Folha de S. Paulo, escreve que "o plano de 2002 pode perfeitamente bem ser aplicado numa sociedade democrática, aberta, de direito. $\mathrm{O}$ PNDH-3, dos petistas, só poderia ser aplicado numa ditadura" ${ }^{21}$. Considerando que os programas, todos, são pautados pelas regras do jogo alocadas na Constituição de 1988, além de perseguirem os mesmos ideários que amparam a Carta, logo é factível concluir que as críticas acima, se justas, não têm nada a ver com a constitucionalidade ou não do PNDH-3. Seja como for, concedendo o benefício da dúvida às acusações de Katia Abreu e Reinaldo Azevedo, há de se deduzir que o último decreto, quando comparado às edições anteriores do Programa, apresenta diferenças gritantes.

Pelas qualificações dadas ao PNDH-3, descrito como "totalitário" e “aplicável numa ditadura”, poder-se-ia inferir, quiçá, que ele seja um documento maquinado sem diálogo com a sociedade civil, um decreto de gabinete de feitura e imposição arbitrárias. Contudo, já foi mostrado há pouco que o $3^{\circ}$ Programa tem o seu desenvolvimento entrelaçado a espaços de encontro e debate democráticos. As duas edições anteriores, por sua vez, também foram compostas pela conversação entre esferas estatais e societárias. A $1^{\text {a }} \mathrm{CNDH}$, realizada em 1996, foi crucial para a elaboração do PNDH-1 (Oliveira, 2013, p. 36), o qual foi ainda formatado a partir de seminários regionais realizados para o recolhimento de propostas populares e dispostos em várias capitais (São Paulo, Rio de Janeiro, Belém, Porto Alegre e Natal). Em 1997, com um ano de vigência do primeiro decreto, a $2^{\text {a }} \mathrm{CNDH}$ foi convocada para refletir sobre a efetividade do documento. Daí em diante, CNDHs passaram a ser realizadas anualmente como um espaço aberto de reflexão sobre a situação dos direitos humanos no contexto brasileiro. Foi a partir de recomendações da $4^{\text {a }}$ CNDH (1999) que o PNDH-2 foi concebido. Logo, as críticas recebidas pelo PNDH-3, se feitas em contraposição ao apreço pelos outros PNDHs, não se sustentam caso dirigidas especificamente à presença ou não de consultas à sociedade civil quando da elaboração dos documentos. Nesse ponto, não há contraste entre os decretos. Também não há distinção no que se refere à concepção de direitos humanos que escora os programas. Não é só a $3^{\mathrm{a}}$ edição que se fundamenta na perspectiva de que os diferentes direitos são, na realidade, interdependentes e

\footnotetext{
${ }^{21}$ AZEVEDO, Reinaldo. Ainda o golpe dos direitos humanos: Desconstruindo outra mentira. Disponível em: http://veja.abril.com.br/blog/reinaldo/geral/ainda-o-golpe-dos-direitos-humanosdesconstruindo-outra-mentira. Data da publicação: 10/01/2010. Acesso em 03/08/2013.
} 
relacionais. O primeiro e o segundo PNDHs também têm por base tal perspectiva holística. A partir da Conferência Mundial de 1993, de onde emergiu a ideia dos Programas Nacionais, reconhece-se que os direitos humanos são indivisíveis. Não são apenas direitos civis e políticos, mas também direitos sociais, econômicos e culturais (Adorno, 2010, p. 11).

Há, sim, diferenças entre um PNDH e outro no que se refere à ampliação e aprofundamento do escopo de direitos humanos a serem protegidos: se o PNDH-1 apresenta sinteticamente esses direitos, o PNDH-2 procura alargar o rol, enquanto o PNDH-3, além de continuar ampliando a lista de direitos, delineia em detalhes os alvos e os responsáveis para a sua efetivação. $\mathrm{O}$ decreto atualmente em vigor pormenoriza como deve dar-se o cumprimento de suas metas, indicando, de antemão, aqueles que devem responder por cada ato de concretização do plano. O Programa preestabelece, inclusive, quais as articulações e os parceiros - não só pertencentes à estrutura do poder público - que serão procurados para tal fim. Ainda, esse é o primeiro PNDH para o qual foram preestabelecidos Planos de Ação e um Comitê de Acompanhamento e Monitoramento. O Comitê conta com representantes de 21 ministérios e sobre ele recai a responsabilidade de elaborar os Planos de Ação, que devem estabelecer prioridades bianuais, para que as proposições do Programa Nacional sejam colocadas em prática. ${ }^{22}$ Ou seja, os Planos de Ação devem ter em vista o que foi colocado no conjunto do $\mathrm{PHDH}-3$, com balizas de prazo variado, e repartir esse conteúdo em metas realizáveis num período determinado, que, no caso, é de dois anos. Importante deixar claro que cabe ao Comitê não só a formulação do Plano, mas também a supervisão do andamento das atividades pré-estipuladas. $\mathrm{Na}$ realização das tarefas que lhe cabem, o Comitê, formado somente por órgãos do Poder Executivo, pode "convidar representantes dos demais Poderes, da sociedade civil e dos entes federados para participarem de suas reuniões e atividades" ${ }^{23}$.

Existe também diferença por parte do PNDH-3 quanto ao estilo de escrita empregado. Em comparação com os outros Programas, no último decreto a linguagem utilizada é menos contida e mais "desabrida", como disse o ex-ministro

\footnotetext{
22 LOPES, José Henrique. Governo Dilma herdará processo de implantação do Programa Nacional de Direitos Humanos. Disponível em: http://noticias.r7.com/brasil/noticias/governo-dilma-tera-missaode-colocar-em-pratica-acoes-do-programa-nacional-de-direitos-humanos-20101128.html. Data da publicação: 02/12/2010. Acesso em 13/03/2014.

${ }^{23}$ Decreto número 7.037, de 21 de dezembro de 2009, página 2.
} 
da Justiça José Gregori, responsável pela primeira feitura do documento ${ }^{24}$. De todo modo, o que chama mesmo a atenção - e as controvérsias - para o decreto de 2009 não é tanto uma possível "falta de modos" na exposição das demandas anunciadas. Não é também o nível de detalhamento do $3^{\circ}$ Programa o causador de debates acalorados. O que esteve e ainda se encontra em disputa são certas proposições espaçadas ao longo dos objetivos estratégicos que constituem o documento. Alguns dos lances mais polêmicos do programa encontram-se, por exemplo, no Eixo Orientador VI, que versa sobre o regime ditatorial que vigorou entre 1964 e 1985. No interior do eixo, está a diretriz 23, a qual tem como objetivo "promover a apuração e o esclarecimento público das violações de Direitos Humanos praticadas no contexto da repressão política ocorrida no Brasil". Com esse alvo definido, o Programa propõe a formação de um grupo de trabalho encabeçado por membros dos Ministérios da Justiça e da Defesa e constituído também por representantes da Casa Civil e da Secretaria Especial de Direitos Humanos, que deveria elaborar, até o mês de abril seguinte, um projeto de lei que fundasse uma Comissão Nacional da Verdade. O propósito da comissão, que ainda teria de ser aprovada pelo Congresso, seria o de investigar arbitrariedades perpetradas graças ao regime militar:

Colaborar com todas as instâncias do Poder Público para a apuração de violações de Direitos Humanos, observadas as disposições da Lei $N^{o}$ 6.683, de 28 de agosto de 1979 [a Lei de Anistia]; promover, com base no acesso às informações, os meios e recursos necessários para a localização e identificação de corpos e restos mortais de desaparecidos políticos; identificar e tornar públicas as estruturas utilizadas para a prática de violações de Direitos Humanos, suas ramificações nos diversos aparelhos do Estado e em outras instâncias da sociedade; registrar e divulgar seus procedimentos oficiais, a fim de garantir o esclarecimento circunstanciado de torturas, mortes e desaparecimentos,

\footnotetext{
${ }^{24}$ RODRIGUES, Fernando. Planos de Lula e FHC têm pontos em comum. Disponível em: http://www1.folha.uol.com.br/fsp/brasil/fc1201201007.htm. Data da publicação: 12/01/2010. Acesso em 31/07/2013.
} 
devendo-se discriminá-los e encaminhá-los aos órgãos competentes ${ }^{25}$.

Resta deixar claro que a comissão se limitaria a apurar as arbitrariedades, não lhe cabendo a o papel de punir qualquer um dos envolvidos, o que é dever da Justiça e apenas dela.

A proposta de criação dessa comissão resultou num grande desconforto para membros das Forças Armadas. Entrar no desenrolar dessas polêmicas, porém, exigiria um nível de detalhamento que foge ao escopo desta sessão. Basta apenas dizer que, com a assinatura do decreto presidencial, os comandantes do Exército e da Aeronáutica proclamaram pedidos de demissão caso os trechos relativos à Comissão Nacional da Verdade não fossem retirados da pauta. Após pressão advinda das Forças Armadas, também o ministro da Defesa ameaçou deixar seu cargo. $\mathrm{Na}$ intenção de estancar a crise, o presidente Lula retirou do documento expressões como "repressão ditatorial” e "perseguidos políticos". Também não se fala mais em apurar transgressões aos direitos humanos especificamente no período militar, mas sim desde a década de 1940 até a reativação democrática nos anos $1980^{26}$. Mesmo que com o recuo, a Comissão Nacional da Verdade foi criada pela Lei 12528/2011 ${ }^{27}$.

Uma outra polêmica do PNDH-3 adveio do Eixo Orientador V, que trata da educação e cultura em direitos humanos. Lá está inclusa a diretriz 22, a qual fala em garantir o direito à comunicação democrática e em assegurar o acesso à informação para consolidação de uma cultura em direitos humanos. No interior dessa diretriz, estão previstas as seguintes medidas:

A criação de marco legal [...] estabelecendo o respeito aos Direitos Humanos nos serviços de radiodifusão (rádio e televisão) [...] prevendo penalidades administrativas como

\footnotetext{
25 Diretriz 23; Objetivo estratégico I; ação programática "a" do decreto número 7.037, de 21 de dezembro de 2009.

${ }^{26}$ COIMBRA, Cecília. Plano Nacional de Direitos Humanos - PNDH-3: O Recuo do Planalto.

Disponível em: http://www.torturanuncamais-rj.org.br/jornal/gtnm_72/pndh3.html. Data da publicação: julho de 2010. Acesso em 17/03/2014.

${ }^{27}$ Mais informações sobre a Comissão disponíveis em:

http://www.cnv.gov.br/index.php. Acesso em 17/03/2014.
} 
advertência, multa, suspensão da programação e cassação, de acordo com a gravidade das violações praticadas ${ }^{28}$. [...] Promover diálogo com o Ministério Público para proposição de ações objetivando a suspensão de programação e publicidade atentatórias aos Direitos Humanos $^{29}$. [...] Suspender patrocínio e publicidade oficial em meios que veiculam programações atentatórias aos Direitos Humanos ${ }^{30}$. [...] Elaborar critérios de acompanhamento editorial a fim de criar ranking nacional de veículos de comunicação comprometidos com os princípios de Direitos Humanos, assim como os que cometem violações ${ }^{31}$.

O fundamento constitucional dessas proposições estaria nos artigos 220 e 221 da Carta Magna, que estabelece a regularização federal da produção das emissoras de rádio e televisão. O artigo 224 da Constituição prevê ainda a implementação, pelo Congresso Nacional, de um Conselho de Comunicação Social.

Setores representativos da imprensa, como a Associação Brasileira de Emissoras de Rádio e Televisão, reagiram fortemente ao denominado "controle social da mídia", o qual foi taxado como uma proposta mal disfarçada de censura. Em resposta àqueles que viam na pauta um cerceamento dos meios de comunicação, o então ministro da Secretaria Especial de Direitos Humanos da Presidência da República, Paulo Vannuchi, um dos principais idealizadores do PNDH-3, respondeu que não havia necessidade de alteração da proposta: "foi interpretado como censura aquilo que é um chamamento à parceria” ${ }^{, 32}$. Em suas palavras, a intenção era

\footnotetext{
28 Diretriz 22; objetivo estratégico I, ação programática "a” do decreto número 7.037, de 21 de dezembro de 2009.

${ }^{29}$ Diretriz 22; objetivo estratégico I, ação programática "b" do decreto número 7.037, de 21 de dezembro de 2009.

30 Diretriz 22; objetivo estratégico I, ação programática "c" do decreto número 7.037, de 21 de dezembro de 2009.

${ }^{31}$ Diretriz 22; objetivo estratégico I, ação programática " $d$ " do decreto número 7.037, de 21 de dezembro de 2009.

${ }^{32}$ Agência Brasil. Governo admite rever três pontos do Plano Nacional de Direitos Humanos. Disponível em: http://www1.folha.uol.com.br/folha/brasil/ult96u707934.shtml. Data da publicação: 16/03/2010. Acesso em 13/03/2014.
} 
estimular projetos como o Prêmio Vladimir Herzog e a Andi (Agência de Notícias dos Direitos da Infância). Também haveria nessa diretriz do PNDH-3, segundo o Secretário, a motivação de incentivar campanhas da Câmara dos Deputados, como a denominada "Quem financia a baixaria é contra a cidadania". Ainda que com tal defesa, o programa foi bastante modificado no que concerne à maior regulamentação do conteúdo veiculado pela mídia. Foi preservada a fundação de um marco legal de respeito aos direitos humanos nos serviços de radiodifusão (rádio e televisão), mas eliminadas as punições para organizações acusadas de desrespeito a esses direitos. Saiu de cena também o ranking das empresas de comunicação comprometidas com os direitos humanos ${ }^{33}$.

O PNDH-3 também despertou contendas com o Eixo Orientador IV, que trata de segurança pública e combate à violência. Lá está a diretriz 17, focada nas possibilidades de promoção de maior acesso à Justiça no campo e na cidade. Com os Ministérios do Desenvolvimento Agrário e da Justiça como responsáveis, foi sugerida a proposição de um projeto de lei para regularizar a mediação em casos de conflitos por território.

Propor projeto de lei para institucionalizar a utilização da mediação como ato inicial das demandas de conflitos agrários e urbanos, priorizando a realização de audiência coletiva com os envolvidos, com a presença do Ministério Público, do poder público local, órgãos públicos especializados e Polícia Militar, como medida preliminar à avaliação da concessão de medidas liminares, sem prejuizo de outros meios institucionais para solução de conflitos ${ }^{34}$.

Ou seja, a proposta era que pudessem haver audiências entre as partes envolvidas num dissenso, e que essas audiências mediadoras e juridicamente válidas

33 CANTANHÊDE, Eliane; IGLESIAS, Simone. Governo recua em plano de direitos humanos. Disponível em: http://www1.folha.uol.com.br/fsp/brasil/fc1405201018.htm. Data da publicação: 14/05/2010. Acesso em 17/03/2014.

34 Diretriz 17; objetivo estratégico VI, ação programática "d" do decreto número 7.037, de 21 de dezembro de 2009. 
se dessem previamente a uma eventual reintegração de posse, a qual não seria mais, portanto, imediata e automática.

Não demorou muito e a bancada ruralista no Congresso e o próprio Ministério da Agricultura passaram para o lado dos críticos do $3^{\circ}$ Programa. As polêmicas, no caso, foram desencadeadas a partir de protestos da Confederação Nacional de Agricultura e Pecuária do Brasil (CNA). Falando como presidente da Confederação, a já citada senadora Katia Abreu declarou em entrevista coletiva que o PNDH-3 não era outra coisa senão uma "plataforma amplamente socialista" transpassada por um "atestado de preconceito contra o agronegócio": "Dificultar a reintegração de posse é estimular invasões de terra" ${ }^{, 35}$. O ministro da Agricultura juntou-se à CNA com declarações na mesma direção: "[O PNDH-3] demonstra certo preconceito em relação à agricultura comercial" e pode criar "insegurança jurídica" no campo ${ }^{36}$. A Secretaria Especial de Direitos Humanos divulgou nota para rebater as críticas da presidente da $\mathrm{CNA}^{37}$ e o MST (Movimento dos Trabalhadores Rurais Sem Terra) também entrou no embate ${ }^{38}$. Por fim, o texto do PNDH-3 recuou mais uma vez. Continuou-se a falar em proposta de projeto de lei para institucionalizar a utilização da mediação em conflitos agrários e urbanos, mas as concessões de mandados de reintegração de posse não necessitariam de audiências coletivas prévias (Oliveira, 2013, p. 42). A utilização da mediação nos conflitos territoriais não estava afastada, muito pelo contrário, mas a retirada de possíveis invasores continuaria não condicionada a audiências prévias de conciliação.

\section{O PNDH-3 e a indignação católica}

\footnotetext{
${ }^{35}$ Agência Brasil. Presidente da CNA diz que Plano Nacional de Direitos Humanos é contra o setor rural. Disponível em: http://noticias.r7.com/brasil/noticias/presidente-da-cna-diz-que-planonacional-de-direitos-humanos-e-contra-o-setor-rural-20100107.html. Data da publicação: 07/01/2010. Acesso em 14/03/2014.

${ }^{36}$ QUERO, Caio. Stephanes vê 'preconceito' em plano de direitos humanos. Disponível em: http://www.bbc.co.uk/blogs/portuguese/br/2010/01/stephanes-ve-preconceito-em-pl.html. Data da publicação: 08/01/2010. Acesso em 14/03/2014.

37 MELLO, Marina. Para setor rural, Plano de Direitos Humanos favorece invasões. Disponível em: http://noticias.terra.com.br/brasil/politica/para-setor-rural-plano-de-direitos-humanos-favoreceinvasoes,25180ddee900b310VgnCLD200000bbcceb0aRCRD.html. Data da publicação: 07/01/2010. Acesso em 14/03/2014.

${ }^{38}$ A nota pública assinada pelo MST está disponível: http://www.mst.org.br/node/8938. Data da publicação: 14/01/2010. Acesso em 14/03/2014.
} 
Não bastasse, porém, despertar conflitos com setores cruciais do agronegócio, da imprensa e das Forças Armadas, o PNDH-3 também trouxe para si o repúdio de alas consideráveis da Igreja Católica Romana. O decreto entrava assim em rota de colisão com mais um estrato social de enorme influência. Na época da publicação do documento, grupos evangélicos estavam majoritariamente preocupados em bater de frente com o Projeto de Lei 122 de 2006, que tem por objetivo criminalizar a homofobia no Brasil ${ }^{39}$, de modo que coube principalmente a parcelas católicas as tentativas de barrar medidas do programa que pudessem ir contra aqueles ideários de feitio cristão.

No que diz respeito à descriminalização ou não do aborto, o PNDH-1 silencia completamente a respeito. O PNDH-2 toca no tema e chega a falar no aborto como "tema de saúde pública" 40 e em "alargamento dos permissivos para a prática do aborto legal" "41, mas não entra em detalhes sobre o que constituiria esse alargamento. De resto, o $2^{\circ}$ Programa trata de direitos reprodutivos numa formulação semelhante a atual inscrição legal (Adorno, 2010, p. 14). É citada a importância de campanhas de pré-natal e faz-se alerta para os riscos de uma gravidez na adolescência. Nessa direção, é proposto que se desenvolvam programas educacionais voltados ao planejamento familiar, com a divulgação das possibilidades de "acesso aos métodos anticoncepcionais no âmbito do SUS" (o que já é polêmico para Igreja). No último PNDH, a problemática do aborto é apresentada e tratada como pertencente ao âmbito da decisão individual:

Garantia dos direitos das mulheres para o estabelecimento das condições necessárias para a sua plena cidadania: [...] Apoiar a aprovação do projeto de lei que descriminaliza o aborto, levando em conta a autonomia das mulheres para decidir sobre seus corpos ${ }^{43}$.

\footnotetext{
${ }^{39}$ O Projeto de Lei está disponível em: http://www.senado.gov.br/sf/atividade/materia/getPDF.asp?t=45607. Acesso em 14/03/2014.

${ }^{40}$ Decreto número 4.229, de 13 de maio de 2002, proposta geral número 334.

${ }^{41}$ Decreto número 4.229, de 13 de maio de 2002, proposta geral número 179.

42 Decreto número 4.229, de 13 de maio de 2002, propostas gerais números 332, 333 e 335.

43 Diretriz 9; objetivo estratégico III; ação programática "g" do decreto número 7.037, de 21 de dezembro de 2009.
} 
Entre o PNDH-2 e o PNDH-3, o aborto deslocou-se, portanto, do campo da saúde pública - de um campo, pois, de cuidados coletivos - para a dimensão da subjetividade e da escolha individual, agora vistas como fontes legítimas de direitos. Não por acaso o aborto deixa o espaço dedicado, no PNDH-2, à “Garantia do Direito à Saúde, à Previdência e à Assistência Social” e passa, no PNDH-3, para a diretriz de número 9, nomeada "Combate às desigualdades estruturais". Vale dizer que o Ministério da Saúde, a Secretaria Especial de Políticas para as Mulheres da Presidência da República e o Ministério da Justiça deveriam cuidar dessa diretriz.

Continuando aqui a tratar de pautas "indecorosas", o primeiro PNDH se cala uma vez mais quando o assunto é orientação sexual e identidade de gênero, diferentemente do seu sucessor imediato, o qual toca na "regulamentação da parceria civil registrada entre pessoas do mesmo sexo e [...] regulamentação da lei de redesignação de sexo e mudança de registro civil para transexuais"44. O PNDH-3, entretanto, caminha adiante: não só reafirma, no seu estilo peremptório, os objetivos anteriores $^{45}$, mas vai além ao propor o seguinte:

Ações voltadas à garantia do direito de adoção por casais homoafetivos. [...] Reconhecer e incluir nos sistemas de informação do serviço público todas as configurações familiares constituidas por lésbicas, gays, bissexuais, travestis e transexuais, com base na desconstrução da heteronormatividade ${ }^{46}$.

Além disso, o decreto estabelece como objetivo:

\footnotetext{
${ }^{44}$ Decreto número 4.229, de 13 de maio de 2002, proposta geral número 115.

45 Diretriz 10; objetivo estratégico V; ações programáticas " $b$ ", " $e$ ", " $f$ " e "g" do decreto número 7.037, de 21 de dezembro de 2009.

46 Diretriz 10; objetivo estratégico $\mathrm{V}$; ação programática " $\mathrm{d}$ " do decreto número 7.037, de 21 de dezembro de 2009.
} 
Desenvolver políticas afirmativas e de promoção de cultura de respeito à livre orientação sexual e identidade de gênero, favorecendo a visibilidade e o reconhecimento social ${ }^{47}$.

Cabe destacar essa última ação programática, na medida em que a mesma se relacionou diretamente com a futura produção de materiais educativos que promoviam o respeito pela orientação sexual individual. Chamados pejorativamente de "kit gay", os materiais compostos por cartilhas e vídeos foram elaborados pelo governo federal e seriam distribuídos em escolas públicas, mas acabaram cancelados em decorrência da enorme resistência por parte da bancada evangélica no Congresso Nacional ${ }^{48}$.

Outro ponto do PNDH-3 que atiçou os ânimos de fiéis foi a proposta pela retirada de objetos sacrossantos de recintos do poder público. Só que, diferentemente da ocasião do "kit gay", nessa pauta não foram os grupos evangélicos que ficaram em alerta, mas, sim, vários dos católicos.

Objetivo estratégico VI: Respeito às diferentes crenças, liberdade de culto e garantia da laicidade do Estado: [...] Desenvolver mecanismos para impedir a ostentação de símbolos religiosos em estabelecimentos públicos da União ${ }^{49}$.

A proposição visava a manutenção da laicidade estatal, preocupação inexistente nas versões anteriores do PNDH. O ineditismo programático do PNDH-3 não se faz presente, por outro lado, quando o assunto é prostituição. Nesse âmbito, há uma linearidade clara do segundo decreto para o terceiro. O PNDH-2 fala em

\footnotetext{
47 Diretriz 10; objetivo estratégico V; ação programática "a" do decreto número 7.037, de 21 de dezembro de 2009.

${ }^{48}$ CASTRO, Gabriel. Dilma cancela distribuição de 'kit gay' a escolas.

Disponível em: http://veja.abril.com.br/noticia/brasil/dilma-cancela-distribuicao-de-kit-gay. Data da publicação: 25/05/2011. Acesso em 17/03/2014.

49 Diretriz 10; objetivo estratégico VI; ação programática "c" do decreto número 7.037, de 21 de dezembro de 2009.
} 
apoiar programas que se voltem para o resguardo dos direitos de profissionais do sexo, ainda sem entrar no mérito de quais seriam esses direitos e nem em como os proteger $^{50}$. O PNDH-3, mais minuciosamente, fala, na diretriz 7, em garantia de direitos trabalhistas e previdenciários de profissionais do sexo, o que seria feito pela regulamentação da profíssão ${ }^{51}$. A concessão de direitos e de regulamentação seria de responsabilidade do Ministério do Trabalho e Emprego e da Secretaria Especial de Políticas para as Mulheres da Presidência da República. A segunda Secretaria também ficaria responsável pela realização de campanhas para desconstruir os estereótipos historicamente ligados a profissionais do sexo ${ }^{52}$.

Como era de esperar, setores da Igreja Católica reagiram pública e prontamente aos artigos do documento presidencial arrolados acima: "Vemos nessas iniciativas uma atitude arbitrária e antidemocrática", disse d. José Simão, bispo de Assis (SP) e encarregado do Comitê de Defesa da Vida da Regional Sul-1 da CNBB (Conferência Nacional dos Bispos do Brasil), que congrega as dioceses do Estado de São Paulo. Maria Dolly Guimarães, presidente da Federação Paulista dos Movimentos em Defesa da Vida, afirmou: "Esse texto pretende fazer o bem virar mal, e o que é mal virar bem. Devemos fazer uma campanha para conscientizar o povo brasileiro [...]. Creio que o ambão [púlpito de onde se fazem as leituras da Bíblia] vai começar a agir mais" ${ }^{53}$. Um manifesto assinado por 67 bispos e repercutido oficialmente pela Igreja no Brasil rechaçou a proposta de retirada de imagens católicas dos recintos da União: “Os símbolos religiosos expressam a alma do povo brasileiro [...] que ninguém tem o direito de cancelar" ${ }^{\text {"54 }}$. Também a Comissão Episcopal Pastoral para a Vida e a Família da CNBB publicou sua nota:

A dimensão ética defendida pelo Programa impõe a ditadura da laicidade, não respeita a nação brasileira que é religiosa, fere a lei natural, manipula a autêntica visão dos

50 Decreto número 4.229, de 13 de maio de 2002, proposta geral número 185.

51 Diretriz 7; objetivo estratégico VI; ação programática " $n$ " do decreto número 7.037, de 21 de dezembro de 2009.

52 Diretriz 9; objetivo estratégico III; ação programática " $h$ " do decreto número 7.037, de 21 de dezembro de 2009.

${ }^{53}$ CARIELLO, Rafael. Igreja também critica plano de direitos humanos de Lula. Folha de São Paulo, São Paulo, p. A6, 8 de janeiro de 2010.

${ }^{54} \mathrm{O}$ manifesto está disponível em: http://www.cnbb.org.br/regionais/leste-1/1532-manifesto-dosbispos-sobre-o-pndh-3. Data da publicação: 28/01/2010. Acesso em 17/03/2014. 
Direitos Humanos, transformando-os em direitos arbitrários [...]. Repudiamos toda lei ou doutrina que em nome dos Direitos Humanos, defende o aborto, destrói a família, desrespeita o direito natural e impõe o pensamento de uma minoria. A democracia e a ética foram gravemente lesadas neste lamentável episódio ${ }^{55}$.

Por fim, veio a declaração da $48^{\mathrm{a}}$ Assembleia Geral da CNBB. O pronunciamento escrito mirou diretamente o PNDH-3 e foi divulgado após uma votação global em que participaram bispos de todos os rincões do país. Nessa votação, a declaração recebeu 236 votos a favor num total de 248 votos, o que equivale a $95 \%$ dos votantes. Contra a "antropologia reducionista que está na base de certas formulações nas quais pretensos direitos são incluídos entre os Direitos Humanos", a Assembleia Geral colocou-se em "defesa de todos aqueles valores e realidades que dignificam o ser humano, como a família, a religião, a reta compreensão da sexualidade, entre outros":

Nas ações programáticas do $3^{\circ}$ Programa Nacional de Direitos Humanos [...] identificamos [...] determinadas ações que não podem ser aceitas. Reafirmamos nossa posição, já muitas vezes manifestada, em defesa da vida e da família, da dignidade da mulher, do direito dos pais à educação religiosa e ética de seus filhos, do respeito aos símbolos religiosos, e contrária à prática e à descriminalização do aborto, ao 'casamento' entre pessoas do mesmo sexo, à adoção de crianças por casais homoafetivos e à profissionalização da prostituição ${ }^{56}$.

\footnotetext{
${ }^{55} \mathrm{~A}$ íntegra da nota está disponível em: http://arquifln.org.br/detalhe_00500.php?cod_select=4195\&cod_002=1\&pagina=5\&lista=1\#finalpa gina. Data da publicação: 13/01/2010. Acesso em 30/07/2013.

${ }^{56}$ A declaração toda está disponível em: http://www.cnbb.org.br/imprensa-1/sala-de-imprensa/notas-e-declaracoes-3/3342-3o-programanacional-de-direitos-humanos-pndh-3. Data da publicação: 15/05/2010. Acesso em 17/03/2014.
} 
No mesmo dia dessa declaração, o Governo divulgou uma nova e definitiva versão do programa ${ }^{57}$. Após enérgicas repercussões eclesiásticas negativas, o item que versava sobre a retirada de símbolos religiosos de estabelecimentos da União foi sumariamente eliminado no decreto reformulado. Já a ação que tratava da legalização do aborto teve sua redação revista, passando a ênfase à consideração do aborto enquanto questão de saúde pública. O posicionamento favorável à legalização deixava assim o léxico da cidadania e da "autonomia das mulheres para decidir sobre seus corpos" e voltava-se para a esfera dos cuidados coletivos. Como um aparente contrapeso a essa "suavização", o decreto contou com a adição do seguinte anexo singelo, mas "escandaloso":

- Recomenda-se ao Poder Legislativo a adequação do Código Penal para a descriminalização do aborto ${ }^{58}$.

Os outros pontos-chave continuaram intactos na pauta definitiva.

Ao admitir que não estava feliz com as modificações realizadas no PNDH-3, o ministro Paulo Vannuchi, principal mentor do programa, falou na época: "vou acordar cedo amanhã para ler os jornais e ver as reações contrárias às mudanças" ${ }^{59}$. $\mathrm{E}$ as reações de fato vieram. Entre as muitas respostas contrárias às modificações do documento, a "Campanha pela integralidade e implementação do PNDH-3" foi sem dúvida a principal. Trata-se de campanha de âmbito nacional, oficialmente ainda vigente, articulada por movimentos sociais, sindicatos, redes, ONGs e outras entidades da sociedade civil comprometidas com a promoção dos direitos humanos no país. Essas organizações todas se reuniram para defender que o PNDH-3 permanecesse em seu formato original, aquele anterior aos recuos do governo feitos em consequência da pressão de parcelas da mídia, do agronegócio, das forças

\footnotetext{
${ }^{57}$ Decreto número 7.037, de 21 de dezembro de 2009, atualizado pelo Decreto número 7.177, de 12 de maio de 2010. Disponível em: http://portal.mj.gov.br/sedh/pndh3/pndh3.pdf. Acesso em 30/05/2013.

${ }^{58}$ Diretriz 9; objetivo estratégico III; ação programática "g" da segunda versão do PNDH-3.

${ }^{59}$ CATANHÊDE, Eliane; IGLESIAS, Simone. Governo recua em plano de direitos humanos. Disponível em: http://www1.folha.uol.com.br/fsp/brasil/fc1405201018.htm. Data da publicação: 14/05/2010. Acesso em 17/03/2014.
} 
armadas e da Igreja Católica ${ }^{60}$. Ao lado dessa manifestação conjunta, organizações de dentro e de fora da campanha, como a CUT (Central Única dos Trabalhadores), a UNE (União Nacional dos Estudantes) e a Plataforma DhESCA Brasil (representação da UNESCO no país), também já haviam lançado individualmente manifestos em oposição aos ataques sofridos pelo PNDH-3. Se, para várias organizações sociais, as modificações do PNDH-3 foram além da conta, para muitas das hostes católicas, pelo contrário, essas alterações não foram suficientes. O que era previsível, afinal, itens como legalização do aborto, casamento gay, adoção por casais homoafetivos, concessão de direitos para profissionais do sexo permaneceram vigentes no programa remodelado. O teor da insatisfação eclesiástica, por sua vez, seria observado por todos no segundo semestre daquele ano de 2010, quando se iniciariam as disputas eleitorais para a Presidência da República.

No dia 29 de outubro de 2010, a dois do turno derradeiro das eleições, eis que na primeira página do jornal de maior circulação no país se escancara a foto do candidato José Serra, em campanha, a beijar devotamente uma imagem de Nossa Senhora da Abadia. Acima da foto, a primeira manchete em destaque na data: "Papa cobra ação de bispos do Brasil contra o aborto - Bento 16 afirmou a religiosos [...] que é dever dos bispos intervir na campanha política"61. No mesmo mês, havia sido apresentada a "Carta da Dilma", texto entregue a líderes religiosos que apoiavam a campanha do Partido dos Trabalhadores. A publicação fora lançada para ser distribuída em igrejas e cultos. Na carta-compromisso, Dilma Rousseff afirmava: "Sou pessoalmente contra o aborto e defendo a manutenção da legislação atual sobre o assunto" $" 62$. A mesma candidata, quando Ministra-chefe da Casa Civil, havia dito que "tem de haver descriminalização do aborto. Hoje, no Brasil, é um absurdo que não haja a descriminalização" ${ }^{\text {"63 }}$. Em resposta à mudança no discurso de Dilma, José

\footnotetext{
${ }^{60} \mathrm{O}$ texto de lançamento da campanha pode ser encontrado em: http://pndh3.com.br/noticias/organizacoes-lancam-campanha-em-defesa-da-integralidade-eimplementacao-do-pndh-3/. Acesso em 17/03/2013.

${ }^{61}$ A capa citada está disponível em: http://www1.folha.uol.com.br/fsp/inde29102010.shl. Data da manchete: 29/10/2010. Acesso em 13/03/2014.

62 PIRES, Carol. Em carta, Dilma assina compromisso contra o aborto. Disponível em: http://www.estadao.com.br/noticias/nacional,em-carta-dilma-assina-compromisso-contra-oaborto,625257,0.htm. Data da publicação: 15/10/2010. Acesso em 13/03/2013.

${ }^{63}$ SILVA, Fernando de Barros. Nas trevas de Deus. Folha de São Paulo, Sâo Paulo, p. A2, 6 de outubro de 2010.
} 
Serra sugeriu, na bancada do Jornal Nacional, ser o mais religioso da campanha: "Eu sou uma pessoa religiosa. Não é nada forçado [...]. Aliás, a candidata não fez outra coisa senão passar a visitar igrejas, coisa que ela não fazia" ${ }^{\text {"64 }}$. Sem grandes espantos, porém: esses são apenas mais alguns episódios sacros no cotidiano da pitoresca luta eleitoral que se presenciou já na prorrogação da primeira década deste novo século. Se observados os eventos vários que caracterizaram a última disputa presidencial, fica difícil pensar algum pleito político ao cargo central da nação, ao menos na história da Nova República, em que as tentativas de influência do campo religioso tenham se dado de forma tão descarada (Pierucci, 2011).

Em meio a essa efervescência cristã, o Presidente da Convenção Nacional das Assembleias de Deus, o pastor Manoel Ferreira, apresentava um remédio que seria tiro e queda para interromper de vez esse cenário de "Tea Party dos trópicos" dar cabo do PNDH-3 - "Esse documento é o centro irradiador de toda a polêmica"66. À marcha católica contra o $3^{\circ}$ Programa, agora se somava o poder de coação política do aparato evangélico. Na campanha para a sucessão presidencial, religiosos de diversas confissões e denominações se centraram numa só trincheira. Mais do que deter "a escalada ao poder [...] de uma mulher sem Deus" (ibid, p. 5), o que estava em jogo era tentar derrubar o PNDH-3. Esse fato é bem exemplificado pela postura do ex-governador do Rio de Janeiro, Anthony Garotinho (PR-RJ), que acabava então de ser eleito o deputado federal mais votado do Estado. Famoso por arrastar consigo o voto em massa de evangélicos, Garotinho declarou que a sua única condição para enfim manifestar apoio no segundo turno à candidatura do PT era que o presidente Lula revogasse completamente o novo $\mathrm{PNDH}^{67}$. Ainda no primeiro turno, o já citado Regional Sul-1 da CNBB, que havia expressado sua oposição ao Programa Nacional logo que ele fora lançado, continuava em sua cruzada. Assinado pela presidência do Regional em nome do conselho episcopal, o texto intitulado

\footnotetext{
${ }^{64}$ A íntegra da entrevista de Serra está disponível em: http://g1.globo.com/jornal-nacional/noticia/2010/10/jose-serra-e-entrevistado-na-bancada-dojornal-nacional.html. Data da publicação: 19/10/2010. Acesso em 14/03/2014.

${ }^{65}$ RODRIGUES, Fernando. Tea Party dos trópicos. Disponível em: http://www1.folha.uol.com.br/colunas/fernandorodrigues/1258288-tea-party-dos-tropicos.shtml. Data da publicação: 06/04/2013. Acesso em 14/03/2014.

${ }^{66}$ SEQUEIRA, Claudia Dantas; RODRIGUES, Alan. A cruzada contra a guerra suja. Disponível em: http://www.istoe.com.br/reportagens/105221_A+CRUZADA+CONTRA+A+GUERRA+SUJA. Data da publicação: 08/10/2010. Acesso em 14/03/2014.

${ }^{67}$ SALME, Flávia. Garotinho diz que apoia Dilma se Lula revogar o PNDH 3. Disponível em: http://ultimosegundo.ig.com.br/garotinho+diz+que+apoia+dilma+se+lula+revogar+o+pndh+3/n123 7795685862.html. Data da publicação: 08/10/2010. Acesso em 14/03/2014.
} 
"Apelo a todos os brasileiros e brasileiras" fala do PNDH-3 como aquele que levou “às últimas consequências esta política antinatalista de controle populacional, desumana, antissocial e contrária ao verdadeiro progresso do nosso País". Em seguida, o panfleto recomenda que, "nas próximas eleições, deem seu voto somente a candidatos ou candidatas e partidos contrários à descriminalização do aborto" 68 . Da mesma forma, José Serra também atribuiu a polêmica eleitoral à inclusão do aborto nas pautas do decreto: "Quem introduziu esse ingrediente na campanha foi o PT e foi a Dilma [...] O PT, no fim do ano passado, fez o PNDH, que tornava transgressor, criminoso, quem fosse contra o aborto. Eles puseram a questão no ar" ${ }^{\prime 69}$. Em resposta às controvérsias religiosas, a candidata anunciou em sua "Carta da Dilma": "[O PNDH3] está sendo revisto e, se eleita, não pretendo promover nenhuma iniciativa que afronte a família”.

No primeiro dia de 2011, Dilma assumiu o cargo de presidente do Brasil. No terceiro dia do novo governo, a deputada federal Maria do Rosário (PT-RS) recebeu o título de Ministra da Secretaria de Direitos Humanos da Presidência da República. No discurso de posse, Rosário prometeu cumprir as metas do PNDH-3 sem cogitar novas mudanças no decreto ${ }^{70}$. Ainda no mês anterior, quando fora confirmada para comandar a pasta, ela já havia declarado que o Programa não seria mais modificado. Questionada especificamente sobre a concessão de benefícios previdenciários a profissionais do sexo, sobre adoção por casais gays e sobre descriminalização do aborto, Rosário disse que cabia à sua equipe "seguir plenamente o que o plano de direitos humanos estabeleceu" ${ }^{\prime 1}$. Pronto. Foi o bastante para que as controvérsias religiosas em torno do PNDH-3 perdurassem junto ao mandato que se iniciava.

\footnotetext{
${ }^{68}$ BONIN, Robson. Bispo de Regional da CNBB defende divulgação de panfleto contra Dilma. Disponível em: http://g1.globo.com/especiais/eleicoes-2010/noticia/2010/10/bispo-de-regional-dacnbb-defende-divulgacao-de-panfleto-contra-dilma.html. Data da publicação: 17/10/2010. Acesso em 14/03/2014.

${ }^{69}$ FRANCO, Bernardo Mello. PT pôs aborto na campanha, diz Serra. Disponível em:

http://www1.folha.uol.com.br/fsp/poder/po2010201022.htm. Data da publicação: 20/10/2010. Acesso em 14/03/2014.

70 GUIMARÃES, Larissa. Maria do Rosário pede ao Congresso que aprove criação da Comissão da Verdade. Disponível em: http://www1.folha.uol.com.br/poder/2011/01/854102-maria-do-rosariopede-ao-congresso-que-aprove-criacao-da-comissao-da-verdade.shtml. Data da publicação: 03/01/2011. Acesso em 14/03/2014.

${ }^{71}$ FOREQUE, Flávia. Ministra defende adoção por casal gay. Disponível em: http://www1.folha.uol.com.br/fsp/poder/po1812201022.htm. Data da publicação: 18/12/2010. Acesso em 14/03/2014.
} 


\section{A secularização e o seu contrário: Por uma definição de conservadorismo católico}

As questões que movem esta pesquisa podem ser resumidas em uma: qual é o prestígio atual do catolicismo conservador dentro da Igreja e também junto ao Estado brasileiro? Porém, a tentativa de resposta a essa pergunta cruza-se com outra interrogação que, apesar de contida na primeira, a precede analiticamente: a que exatamente se deseja referir quando se fala em catolicismo conservador? Dada a ampla gama de prenoções que se avolumam no uso mais do que corrente dos adjetivos "católico" e "conservador", fez-se necessário um exercício de elucidação conceitual, tendo em vista a reconstrução do termo "católico-conservador" para a sua utilização nas condições estritas de categoria sociológica descritiva. Com o afastamento dos pressupostos de senso comum, o que se procurará com o emprego da expressão citada são os ganhos classificatórios que ela pode propiciar para uma análise rigorosa. E para que assim seja feito, é imprescindível a fixação sistemática dos nomes nas coisas, o que não implica, importante deixar claro, a busca por “definições definitivas" de sentidos terminológicos. Trata-se simplesmente de localizar, em meio a múltiplas confusões de significados, uma definição conceitual mínima, talvez provisória, pois instrumental, que tenha por finalidade imediata a investigação aqui em processo.

A realização de um recorte definidor mostra-se indispensável para viabilizar o esforço de análise interpretativa que se quer empreender. Tendo tal necessidade em conta, a sessão que agora se inicia procura mostrar, de início, em que pé está a discussão acadêmica em torno do clássico conceito sociológico de secularização. Já há décadas, busca-se uma melhor delimitação do conceito. Em meio a essas tentativas de demarcação, entrecruzam-se entrincheiradas disputas entre autores que consideram dever ser descartada a tese da secularização, que já teria dado mostras de ser falha, e pesquisadores que ainda acreditam no vigor e utilidade da teoria a respeito. É proveitoso deter-me nesse debate na medida em que o conservadorismo católico como categoria investigativa será recortado a partir do conceito de secularização. Desse modo, os dois primeiros itens desta sessão focam não só as definições de secularização em voga, mas também as querelas teóricas derivadas da 
busca pela exclusão ou pela permanência do conceito no léxico das ciências sociais. O segundo item, entretanto, vai além dessas contendas e propõe que, talvez, uma boa saída para o quebra-cabeças seja dar à secularização o tratamento teórico que se confere a um tipo ideal. Pensar a secularização nesses termos facilita ainda a qualificação rigorosa do conservadorismo católico, o qual também será tipificado idealmente. Ambos, secularização e conservadorismo católico, formam a tipologia básica da pesquisa e abstraí-los da realidade social proporciona maior destreza no trabalho de caracterização que será executado no terceiro item desta sessão. Ou seja, é essencial, por um momento, escapar ligeiramente do caso concreto em investigação, para que se possa minimizar as equivocidades que perpassam os conceitos-chave da análise: "Luta por clareza. [...] De confusa e embaralhada, basta a vida real"' (Pierucci, 2003, p. 37).

"Saber do que se fala sempre ajuda" (idem, 1998, p. 43): é nesse postulado, simples de tão prático, que se inspira a sessão que se inicia.

\section{"A secularização que importa em primeiro lugar"}

A Igreja Católica é um "objeto selvagem à domesticação" (Pondé, 2011, p. 14). A infinitude de seu alcance (temporal e espacial), os mil intrincados doutrinais e morais, o sem-número de atores em cena (e não só os atores atuais, mas também os antecessores, os quais ainda têm muita presença de palco), tudo se reúne para dar a qualquer investigação sobre o universo eclesial o aspecto do risco e da incerteza. Ou, pelo contrário, dada toda a carga de senso comum presente nas formulações feitas sobre o catolicismo e pelo próprio catolicismo, resulta que uma pesquisa abrangendo tal esfera envolve lidar por vezes com afirmativas de caráter absoluto e com convicções inabaláveis. De todo modo, seja por sua vaga e indefinida imensidão, seja por suas certezas implacáveis, o objeto Igreja mostra-se muitas vezes opaco e de difícil aproximação para a análise. Mas, ainda que com esses entraves, e exatamente por causa deles, cabe então propor uma estratégia investigativa: se a intenção é identificar os aqui nomeados ideários e práticas católico-conservadores, tal pretensão pode tornar-se factível pelo exame preliminar da realidade em oposição à 
qual esses ideários e práticas se erguem. Nesse procedimento há uma indisfarçável apropriação do esboço de conservadorismo idealizado por Karl Mannheim (1986).

Esse autor qualifica a postura conservadora como uma postura de reação ao gradativo término das sociedades e sensibilidades tradicionais. O sistema de pensamento conservador seria, consequentemente, um "contra-sistema", que emerge, vale dizer, por rejeição ao pensamento do direito-natural. De acordo com esse raciocínio, para explicar o conservadorismo, far-se-ia proveitoso, primeiro, compreender a conjuntura que o motiva a se pôr em luta. No propósito de conceber a motivação básica dos conservadores, seria positivo apreender a modernidade contra a qual e em relação à qual eles se mostram ressentidos. Porém, esta pesquisa não trata de um conservadorismo genérico, mas sim daquele propriamente religioso e decisivamente católico. Seguindo os passos de Mannheim, é, então, a questão da modernidade secular que se coloca forçosamente para a análise. Pela compreensão da contemporaneidade laica, poder-se-ia cercar pelas beiradas e, por efeito de contraste, a ortodoxia clerical. Ao destrinchar essa modernização, a expectativa é que, na identificação daquilo que o conservadorismo católico não é, na observação daquilo que ele hostiliza, se mapeie aquilo que ele é.

Contudo, haja vista o embaraço atual que é despertado quando se toca no tema da secularização", falar em "modernidade secular" e em "contemporaneidade laica" pode soar deveras controverso. Fora do Brasil, por exemplo, é grande e só faz crescer o número de pesquisadores que argumentam contra o paradigma sociológico clássico da religião, aquele que pensa o declínio da fé na razão direta do progresso da modernidade capitalista. Esses estudiosos armam seu posicionamento teórico esgrimindo dados que mostrariam um crescimento de novos movimentos religiosos, nas últimas décadas, em sociedades europeias e norte-americanas (cf. Enroth, 2005 e Dawson, 2006) - movimentos que, de tão exóticos e “orientalistas" (Said, 2007), parecem por vezes capazes de dinamitar qualquer princípio de racionalidade cultural. Mas a dessecularização no primeiro mundo não se daria apenas pela comoção de espiritualidades alternativas. Do mesmo modo, também como contraevidência ao processo de secularização, é citado o possível avanço de confissões do cristianismo evangélico (Stark, 2008), para não falar da "invasão islâmica" na

\footnotetext{
1 “É incrível como soa atrevido e torto [...] hoje um sociólogo falar em declínio da religião e ousar qualificá-lo de persistente" (Pierucci, 1998, p. 100).
} 
Europa, que aparentemente ocorre a passos largos (cf. Caldweel, 2010). Essas formas emergentes da religião remeteriam, por sua vez, à incontornável natureza religiosa da condição humana (Barret, 2012), à sede pelo sagrado como necessidade invariável do ser.

Nesta análise, não cabe entrar no mérito de deduções que escapem à alçada sociológica e que assim procedam por meio de apelos de cunho idealista que, na busca pela essência humana abstrata, se reportam a uma ontologia a-histórica. Saindo pela tangente das discussões de raízes metafísicas, resta ainda assim destacar o que soa como uma distorção comum nos argumentos adversários à teoria da religião weberiana. A afirmativa de muitos autores não poucas vezes caminha na direção de apontar uma religiosidade efervescente e plural no que diz respeito ao âmbito privado-íntimo. São as conversões e reconversões particulares - em ebulição, ao que parece - que são colocadas como evidência da ressacralização pela qual se passa. É urgente que se deixe claro, pois, que o processo de secularização, ao menos o tipificado por Weber, seu principal teórico, trata da secularização da sociedade, e de modo algum envolve a supressão contingente da religião no que concerne à esfera individual:

Precisamente os valores últimos e mais sublimes se retiraram da vida pública e se refugiaram ou no reino transcendente da vida mística ou na fraternidade das relações humanas diretas e pessoais. [...] Nada há de acidental no fato de que, hoje em dia, só nos círculos mais pequenos e íntimos, nas situações humanas pessoais, em pianissimo, é que pulsa algo que corresponde ao pneuma profético que nos tempos passados abrasava grandes comunidades e as mantinha coesas (Weber, 1982, p. 182).

Também Mannheim fala da retração para o privado de certas esferas anteriormente públicas (as esferas da vida onde prevalecem os sentimentos pessoais e religiosos), numa espécie de compensação pela crescente racionalização da "vida oficial” em geral. "As relações originais e irracionais do homem com o homem e do 
homem com as coisas" (Mannheim, 1981, p. 94) são impelidas para a periferia da vida do indivíduo, em contraste com a autonomização de esferas mais representativas. "Como se deve esperar, de fato persistiram, mas como geralmente acontece na história, submergiram e tornaram-se latentes, manifestando-se no máximo como uma contracorrente oposta à corrente principal" (idem). Bryan Wilson (1982), na mesma direção, pontua que o sagrado é capaz de ter um valor dos maiores na esfera do exercício devocional privado, o que, contudo, não tem consequências de fôlego no interior das instituições sociais dominantes. Sendo a sociedade moderna caracterizada pela dinâmica generalizada de procedimentos impessoais e burocráticos de controle, os despertamentos religiosos, que poderiam bem ocorrer, ficariam desde já impossibilitados de ter por consequência algum retrocesso na fundamentação da ciência e da república como modelos hegemônicos de organização da vida social. Conclusão com a qual Flávio Pierucci está de acordo: "Desde quando a sociedade moderna repousa sobre as relações pessoais? Delírio microssociológico do mais puro" (Pierucci, 1997, p. 113).

Em outras palavras, digamos que haja uma efusão da fé que vá para além de um efeito midiático amplificador das proporções, refletindo realmente um incremento do significado da religião na existência das pessoas. Ainda assim, mesmo que se experimente hoje, no Brasil e no mundo, um fantástico reavivamento do sagrado, isso em nada desbancaria o processo de secularização, cuja ênfase estaria menos no conteúdo psicossocial das pertenças religiosas e sim nas mudanças estruturais das sociedades tradicionais para as sociedades modernas. Como se vê, para Weber, Mannheim, Wilson e Pierucci, o processo de secularização é a rigor um macroprocesso. Nos trabalhos desses autores, o que recebe a alcunha de secularização é o banimento do religioso do centro que garante a coesão social, é a retirada do sagrado de seu protagonismo na matriz cultural totalizante, é a diminuição de alcance da religião sobre a pluralização das esferas autonomizadas e, principalmente, é a racionalização da ordem jurídico-política, a qual começa com o disestablishment do sagrado para fora da esfera do Estado (idem, 2008a).

Ainda mais do que na luta da modernidade cultural contra a religião, e mesmo mais do que na perda do monopólio da verdade para a ciência, é no declínio da fé como potência in temporalibus que a secularização se imporia de maneira decisiva para a contemporaneidade. Ernst Troeltsch já havia qualificado a 
säkularisation des staates como "o fato mais importante do mundo moderno" (Troeltsch, 2012). De forma idêntica, Pierucci procura mostrar que, com a crescente diferenciação estrutural da religião em relação aos espaços do poder público, se visualiza aquela que ele classifica como a "secularização que importa em primeiro lugar" - a que diz respeito às liberdades civis e políticas de todos e cada um de nós: convivermos "sob o domínio da lei” num Estado democrático de direito.

Oxalá os cientistas sociais e historiadores passássemos pouco a pouco a incorporar, majoritária e rotineiramente, a ideia de secularização do Estado como um componente crucial, se não o mais crucial de todos, da conceituação histórico-social de uma secularização da qual não pode abrir mão toda modernidade que se preze. Toda vez que falo propositivamente em secularização, refiro-me com ênfase à secularização do Estado com seu ordenamento jurídico, e menos à secularização da vida, que essa pode mesmo refluir, mas a do Estado, não. A do Estado, se for para mudar nalgum aspecto, deve ser somente para afiar cada vez mais a nitidez do seu gume (Pierucci, 2008a, p. 12).

E Pierucci vai além. O agito religioso não só não solaparia a secularização, como, pelo contrário, a confirmaria. Por mais paradoxal que possa soar, o que o autor defende é que é possível identificar, no próprio processo de secularização jurídico-política, a causa, logo a explicação, de uma possível efervescência sagrada. Esse cálculo está amparado na perspectiva analítica alçada pelo pesquisador Stephen Warner à condição de "novo paradigma" na sociologia da religião (Warner, 1993). A “teoria das economias religiosas", inaugurada por Rodney Stark e William Sims Bainbridge (1987), mas cujos principais expoentes hoje são Roger Finke (2005) e Laurence Iannaccone (2005), é utilizada por Pierucci para mostrar a existência de um desencadeamento lógico entre racionalização política e ebulição religiosa. Cabe deixar claro, porém, que ao pensar os efeitos da laicização a partir dessa linha teórica, procede-se da mesma forma como Foucault o fez em relação à filosofia de 
Nietzsche: "a única marca de reconhecimento que se pode testemunhar a um pensamento [...] é precisamente utilizá-lo, deformá-lo, fazê-lo ranger, gritar” (Foucault, 1979, p. 143). Stark \& Bainbridge rejeitam toda e qualquer concepção de secularização, mas é justamente a partir das premissas deles que Pierucci esboça que se viveria hoje no país um "processo de secularização possante" (Pierucci, 2008b, p. 21).

Melhor dizendo, o que se enxergaria seria "uma religiosidade galopante no seio de um processo de secularização possante" (idem). A perspectiva fundamentase numa compreensão da racionalização política que se distancia das pouco sofisticadas, as quais tendem a ver, na progressiva diferenciação estrutural do campo do direito e dos negócios públicos, unicamente o mero domínio legal por parte do Estado, dado que norma jurídica autônoma, em relação à religião. Pierucci não nega que o moderno Estado liberal, com seu monopólio legítimo dos meios de repressão (Cf. Weber, 1970), inviabiliza eventuais ações religiosas que aspirem impor seus ditames para o conjunto total dos cidadãos. O sociólogo não nega tampouco que o direito secular, em continuidade, desde já dessacralizado, relega ao plano do privado normatividades outras para além daquela exclusivamente racional-legal, submetendo, independentemente de juízos de fé, cada um e todos ao domínio da "legalidade legítima" - domínio esse que, apesar de implacável, tem a vantagem prática de se apresentar como "revisável" em seus termos, uma vez que não mais sustentável sobre bases teológico-dogmáticas alegadamente imutáveis pois entranhadas de validade absoluta. O que está em análise, e é nesse ponto que Pierucci vai ao encontro de Stark e seus compatriotas, é que a observância generalizada da legislação moderna não significa a instauração de uma plataforma que tenha como mérito em seu "processo civilizador" (Elias, 1997) a emancipação apenas da esfera estatal. Trata-se, em simultâneo, de uma emancipação das crenças e das práticas de fé, ainda que dentro dos limites pré-estabelecidos da soberania legal (cf. Grim; Finke, 2011).

Haveria um reconhecimento por parte das instituições públicas também no que se refere à dignidade intrínseca da identidade religiosa, seja lá qual for o seu conteúdo, desde que esse conteúdo não contrarie a legalidade do Estado democrático de direito. Desse modo, por um lado, a religião perde em capacidade de pressão sobre os rumos políticos, ao menos no que diz respeito a uma pressão feita enquanto 
"divina"; por outro lado, o Estado laico, uma vez que situado no interior do processo de autonomização das competências, ainda que com a ampliação da dominação jurídica e política sobre a esfera religiosa, vê-se obrigado, pela neutralidade em matéria de crença, a manter-se respeitosamente alheio à fé individual.

Tal alheamento estatal passaria longe de uma disposição apenas passiva, contudo, como quem deixa a esfera religiosa ao deus-dará uma vez que não mais the concerne. A desregulação da fé por partes estatais não significa a proclamação de uma realidade anárquica, em que todos se comem vivos sem proteção do poder público, e na qual a livre expressão é entravada segundo o regimento do mais forte. Trata-se, isso sim, de uma regulação mínima que se dá apenas enquanto in extremis, tão somente para garantir a existência de espaços sociais religiosos caracterizados pelo alto grau de pacificação aí presente. O cientista político Anthony Gill diz propriamente que se está em jogo, para a burocracia, sujeitar a religião ao monopólio legítimo dos meios de repressão, também o está a tarefa de assegurar, por meio de tal monopólio, o direito à liberdade de crença garantido constitucionalmente (Gill, 2005). Cabe ao Estado, por si só, em simultâneo com a ausência de intervenção no âmbito doutrinal, a repressão a toda e qualquer tentativa de silenciar as confissões religiosas em suas ações de proselitismo no âmbito das consciências particulares.

Caminho de dupla mão, portanto: com a retirada dos acessórios transcendentes, devolve-se ao poder público o seu aspecto de construção arquitetada sobre os próprios e mundanos pés da política, com leis racionais e discutíveis (Cf. Pierucci, 1998, p. 50); semelhantemente, contudo, o Estado laico assegura também o estabelecimento de limites cada vez mais rígidos às tentativas de controle sobre o exercício religioso, com a desregulação política contínua sobre o campo da fé, mas, além disso, com a garantia de um poder público que se estabeleça minimamente enquanto gerenciador e contentor da violência - aquilo que Adam Smith classifica de uma administração tolerável da justiça (Smith, 2003).

Com a liberdade de fé estabelecida constitucionalmente de modo efetivo, tanto aos agentes demandantes quanto aos agentes ofertantes de crença, o que se constataria, aos olhos de Stark e Finke, seria a resultante diversificação progressiva do campo religioso, vista a pressuposição dedutiva de uma multiplicidade social já dada no âmbito da demanda (Stark; Finke, 2000), que supõe, uma vez ausentes os entraves do poder público, uma correspondente variedade de religiões para satisfazer 
as preferências diferenciadas. Mas o Estado regulador não entrava o mercado apenas por estancar a oferta religiosa, engessando o pluralismo tão ambicionado pela variedade demandante. Ele ainda faz estabelecer monopólios que, como pontua o antropólogo Alejandro Frigerio, além de compreensivelmente impossibilitados de satisfazer as múltiplas exigências da população segmentada, ainda contam com maiores probabilidades de se tornarem menos desejáveis, vista a falta daquela efervescente conflitividade, livre e multidimensional, só possível em situações concorrenciais, a qual, por si só, já constitui motivação mais do que suficiente para as crenças se envolverem na procura sem tréguas por potenciais fiéis, articulando para tal seus agentes, e exigindo-lhes incansável esforço no trabalho de expansão da mensagem salvadora (Frigerio, 2008, p. 24).

Porém não é só de maior mobilização, dedicação e fidelidade que se fazem essas buscas por consumidores desejosos de transcendência; mudanças no interior da própria lógica sacra também fazem parte do processo de incremento da participação competitiva. Não sendo suficiente a disposição das religiões no sentido de alocar suas práticas e conteúdos de crença anteriores ao âmbito econômico em um esquema de mercado, exige-se ainda um avanço do modus operandi mercadológico para dentro do circuito religioso, com o objetivo evidente de satisfazer as aspirações diversas dos adeptos e possíveis fiéis, sob o risco constante de se ficar para trás na disputa por resultados. Como diz Peter Berger, cujo trabalho se assemelha, e muito, ao modelo de Stark \& Bainbridge, especificamente naquilo que concerne à importância concedida ao mercado para a dinâmica religiosa (apesar das discordâncias quantos aos efeitos pluralizantes da laicização):

O que se passa agora é, muito simplesmente, que os grupos religiosos se transformam de monopólios em agências mercantis competitivas [...]. Agora os grupos religiosos devem organizar-se para cortejar uma população de consumidores em competição com outros grupos que têm o mesmo propósito. De imediato a questão dos "resultados" adquire importância (Berger, 1985, p. 169). 
E ainda

\section{[...] A pressão para lograr "resultados" numa situação} competitiva faz entranhar uma racionalização das estruturas sociorreligiosas [...] tal racionalização estrutural se expressa principalmente no fenômeno da burocracia (ibid., p. 176)

Se bastassem, nesse mercantilismo religioso de alto fôlego, apenas mudanças estruturais burocráticas, talvez o impacto da influência mercadológica fosse mais “indolor”, mas os efeitos também se dão, para Berger, naquilo que há de demasiado íntimo, naquele núcleo "imutável e eterno", no conteúdo propriamente doutrinal, o qual também acaba por submeter-se a disposições nas quais, no limite, "o freguês tem sempre razão":

Os efeitos da situação pluralista [...] se estendem aos conteúdos religiosos, isto é, ao produto dos organismos mercantis religiosos [...] é impossivel oferecer no mercado uma mercadoria a uma população de consumidores não constrangidos sem levar em consideração seus desejos no que concerne a dita mercadoria. [...] introduziu-se o controle do consumidor sobre o produto oferecido no mercado (ibid., p. 181).

Há de se entender, então, que as classificações mercadológicas esboçadas, as de crenças e práticas como produtos de consumo e das instituições religiosas como empresas em competição, não remetem somente à aplicação metateórica de um aparato conceitual próprio das ciências econômicas para a investigação do campo religioso. O uso de conceitos da economia implica, sobretudo, a percepção de que, na realidade social da modernidade, existe um avanço da lógica de compra e venda 
sobre a esfera da fé, a qual se vê invadida e transformada - "maculada", diriam os mais ortodoxos - por tal racionalidade profana.

Em resumo, há teorizações menos unívocas do que aquelas que enxergam o andamento do processo de secularização e a emergência de novas e redivivas expressões de fé como coisas mutuamente excludentes. A excitação com o sagrado no plano individual caminharia em paralelo com o declínio da religião no plano jurídico estatal e, mais especificamente, a efervescência adviria desse declínio. Toda essa abstração a respeito do desencadeamento entre ordenamento laicizado, modernidade e pluralismo religioso aparenta ter coerência lógica em suas conclusões analíticas; entretanto, mais importante é o seu mérito argumentativo em articular-se com considerável êxito a abordagens históricas e factuais no que diz respeito às origens do cenário religioso brasileiro contemporâneo. O sociólogo Ricardo Mariano procura mostrar cronologicamente que, no caso nacional, é bastante sensato apontar a laicização do Estado como ato causal primeiro de todo o possível agito dinâmico que vem se dando no plano religioso (Mariano, 2001). Já Pierucci defende que, se se a modernidade religiosa tem alguma coisa para comemorar em terras brasileiras, o seu festejo se deve em grande parte ao longínquo ano de 1889, quando do rompimento republicano, ainda que com consideráveis brechas, das relações mais do que amistosas entre clero e controle monárquico; no mais é consequência desse fato primeiro (Pierucci, 2008b). Também por aqui - conforme delineado tendencialmente pelo novo paradigma -, à medida que nos distanciamos dos tempos em que sobravam regalias monopolísticas, e exatamente por esse distanciamento, o que se tornaria visível seria uma experiência social variada em seus matizes ${ }^{2}$ e impulsionada pela apropriação por parte dos agentes religiosos do que diz respeito à legalidade incontornável da liberdade de fé. Esse apossamento mercantil expressarse-ia na administração racionalizada da criação, manutenção e distribuição das crenças, mantendo sempre o olhar atento para o feedback do consumidor de religião, bem como para os movimentos calculados da concorrência, também tão interessada na disputa por mais seguidores/clientes ${ }^{3}$.

\footnotetext{
${ }^{2}$ CARIELLO, Rafael. País altera mapa da fé, mas não a sua religiosidade. Disponível em: http://www1.folha.uol.com.br/fsp/especial/fj0605200702.htm. Data da publicação: 06/05/2014. Acesso em 30/05/2013.

${ }^{3}$ LIMA, Diana. Anticalvinismo brasileiro. Disponível em: http://www1.folha.uol.com.br/fsp/mais/fs1207200908.htm. Data da publicação: 12/07/2009. Acesso em 30/05/2013.
} 
Desse modo, Mariano e Pierucci caminham na mesma direção de Weber, cuja tese da secularização não se refere ao que vai acontecer num futuro de curto ou longo prazo. Não se trata de profecia acadêmica ou da indicação de um telos cuja ocorrência esteja pré-condicionada, mas, sim, de uma identificação ex-post e objetiva do que já teria ocorrido na abertura da contemporaneidade. Afinal, a formação de todo e qualquer Estado liberal democrático trouxe e traz consigo não menos do que a derrocada da logística do magistério religioso como sustentáculo organizador da geografia política (Michael, 1999, p. 356). No movimento de atribuição da posição soberana ao direito nacional, há, em simultâneo, a desinstalação do pedestal transcendente e sagrado para a legitimidade governamental. Fora do escopo religioso, é aí que se instala a racionalidade utilitário-instrumental do positivismo jurídico, o qual é referência e vetor da desencantada política contemporânea.

Logo, pareceria razoável concluir que, se comparada ao caráter "líquido" (Bauman, 2003) da secularização difusa dos mundos da vida, a secularização jurídico-política se encontraria numa situação muito mais sólida no que diz respeito à sua factualidade empírica facilmente constatável. Voltar os olhos ao Estado traria consigo maiores possiblidades analíticas de medição e avaliação, haja vista que a secularização que se dá nesse âmbito seria historicamente verificável. Dando ainda um passo adiante, talvez fosse possível propor que aí, na laicidade estatal, pudesse ser localizado um ponto inequívoco (dada sua evidência), um mínimo consenso entre inúmeras contestações mútuas sobre a existência ou não de um declínio da fé na modernidade. Se tomado o Estado como locus de análise, poder-se-ia dizer, quem sabe, que, quando se fala em processo de secularização, que se está, finalmente, a tratar de "um fenômeno [...] incontroverso" (Martelli, 1995, p. 274).

Porém, não são poucos os pesquisadores que contravertem essa conclusão “incontroversa". Esses autores apontam para o ressurgimento da religião na esfera pública, inclusive no campo político, em diversos países ocidentais. Incluído na toada desses pesquisadores, Jürgen Habermas se utiliza da expressão "pós-secular" para se referir à presente era (Habermas; Ratzinger, 2007). Já outros preferem falar em "dessecularização" (Berger, 1999). Há ainda análises que não chegam nem a citar uma possível reemergência do sagrado, um retorno da fé, pois os ideários religiosos jamais teriam sido marginalizados em relação à dinâmica das instituições 
sociais dominantes. Não teria havido tal coisa de, na modernidade, a religião ficar circunscrita progressiva e exclusivamente à vida íntima. Por conseguinte, não se trata da fé voltar à ativa no âmbito político, pois ela nunca deixou de se manifestar ali.

\section{Secularização como tipo ideal}

No debate acadêmico, nem todos os que se contrapõem à perspectiva da secularização o fazem a partir de constatações centradas "só nos círculos mais pequenos e íntimos". Se há pesquisadores que se entrincheiram contra a teoria clássica weberiana trazendo para a análise o recinto privado, visto como religiosamente efervescente, há, por outro lado, os que criticam com consistência a ideia de que, no avançar da modernidade, a fé acabaria por se restringir à vida particular, pessoal. Estes últimos não pautam seus argumentos contrários à tese da secularização apenas por demonstrativos da presença da religião nas existências individuais, mas têm, sim, como foco principal, o olhar para a contínua atuação de religiosos na esfera pública.

O sociólogo Josetxo Beriain defende que não existe uma modernidade propriamente dita, mas várias modernidades em constante disputa (Beriain, 2005). Do mesmo modo, o igualmente sociólogo José Casanova considera que há múltiplas e variadas secularizações (Casanova, 2007, p. 5): há tantas secularizações como há modernidades. Radicalizando sua conclusão, Casanova afirma que a teoria da secularização é potencialmente problemática, na medida em que toma o caso europeu, e as desventuras pelas quais teria passado a fé na Europa Ocidental, como um protótipo universalmente explicativo, isto é, como um modelo elucidativo do caminho que outras sociedades acabarão por trilhar. Consequentemente, Casanova propõe que o estudioso leve em conta que "cada caso é um caso" e que, ao falar em secularização, que se atente para o fato de que se está a utilizar uma categoria aplicável prioritariamente às dinâmicas particulares de transformação da realidade 
social europeia ${ }^{4}$. Ao fazer uso do conceito, que não se minorem as singularidades dos contextos locais da realidade em análise. Desse modo, seguindo suas próprias recomendações, o autor de Public Religions in the Modern World (1994) relativiza a teoria da secularização pela análise de realidades nacionais em que teria ocorrido uma "desprivatização" da religião. Tendo o Brasil como um de seus exemplos principais, Casanova sugere que já não dá mais para falar indiscriminadamente na religião como âmbito confinado à vida particular. Após observação de episódios ocorridos no país durante a década de 1980, Public Religions conclui que, no caso brasileiro, é bem possível afirmar que as religiões acharam o seu caminho de volta à arena da sociedade civil, adentrando até o âmbito das discussões políticas. Longe do escopo ocidental das análises que fundam a sociologia, por aqui seria possível ver as religiões reassumindo um papel público atuante.

Com a visão também dirigida ao Brasil, a antropóloga Paula Montero faz ponderações de certa forma semelhantes. Para Montero, o cenário religioso nacional não se pauta atualmente, e, aliás, nunca se pautou, pelo processo de deslocamento da fé para a dimensão privada:

Longe de "privatizar-se", as religiões, desde sempre, imiscuíram-se das mais variadas formas na construção e na gestão do espaço público. A presença histórica das igrejas cristãs nas áreas de educação, saúde, assistência social, etc. correspondeu a uma delegação consentida e pactuada pelo próprio Estado. A concessão pública de canais televisivos e de radiodifusão a confissões religiosas tampouco é um fenômeno recente. No campo da política também já nos habituámos à presença de bancadas religiosas no Congresso (Montero, 2009, p. 9).

\footnotetext{
4 Ricardo Mariano lembra que mesmo no interior da Europa Ocidental, os diversos países apresentam grandes diferenças no que diz respeito à situação de seus cenários religiosos (Mariano, 2011).
} 
A autora leva para os seus trabalhos o alerta que Casanova já havia feito sobre os riscos analíticos da teoria da secularização: "uma vez que a secularização foi concebida como um processo teleológico universal cujo resultado era conhecido de antemão, os cientistas sociais não se interessaram em estudar os diferentes caminhos que as sociedades tomam" (Casanova, 1994, p. 25). Montero, assim como Casanova, considera que o paradigma da secularização está, no mais das vezes, implicitamente amparado numa percepção unilinear da história, a qual enxerga a modernização social como um processo que invariavelmente é acompanhado pela transferência da religião para o mundo privado. Essa visão homogeneizante, por sua vez, impediria de captar as especificidades da formação e definição da laicidade no caso do Brasil, país onde o declínio do poder político da religião não seria condição necessária para a emergência de um Estado democrático moderno. Pela averiguação dos desencadeamentos históricos particularíssimos que resultaram na realidade social das religiões no Brasil, seria possível constatar que "ao ser expulsa, contra a sua vontade, do aparato estatal, a Igreja Católica tornou-se uma força política [...] da esfera civil em construção" (Montero, 2012, p. 170).

Já Pierucci não nega que a Igreja continuou e continua a ter força política no país, mesmo após a separação formal entre religião e Estado. Porém, o sociólogo passa longe da afirmação de Montero, que sustenta já ser "possível prescindir do paradigma da secularização" (Montero, 2006, p. 48). Pelo contrário, para Pierucci, “não há crise de paradigma nessa área do conhecimento" (Pierucci, 1997, p. 104):

Numa sociedade moderna, a religião quando volta à política, seja de que maneira for, mostra ter o fôlego mais curto do que à primeira vista poderá parecer aos eternos descontentes com a autonomização das esferas de valor e a separação de competências. É o tipo de envolvimento que passa (Pierucci, 2008a, p. 11).

Ainda que longe de considerar a secularização como "um processo teleológico universal", Pierucci, mesmo assim, na análise do Brasil de hoje, chega a deduções semelhantes àquelas que Weber esboçou na Alemanha da virada do século 
XIX para o XX. Se Weber diz que só na vida íntima, “em pianíssimo”, é possível falar ainda em efervescência religiosa, Pierucci, por sua vez, dando continuidade às analogias musicais, afirma que a "religião no mundo moderno é sempre-já 'segundo violino"” (Pierucci, 1997, p. 107). E haveria vezes em que até mesmo a metáfora do segundo violino seria forte demais para expressar a importância política do fator religioso. Observando a campanha eleitoral de 2010, que teve na polêmica do PNDH-3 um de seus destaques, Pierucci finaliza sua análise sobre a disputa presidencial afirmando que "nessa eleição, a religião não podia esperar desempenhar outra coisa que um papel de figuração. Que foi afinal o que acabaram fazendo as lideranças eclesiais [...]. Fizeram-no radiosamente, mas sem qualquer chance de protagonismo" (Pierucci, 2011, p. 15). Assim como Casanova e Montero, Pierucci procura dar a devida importância às circunstâncias locais do objeto em investigação; contudo, sua conclusão, oposta às dos dois primeiros, é a de que a "tese da secularização [...] tem pretensão de generalidade, mas [...] parece sobremaneira apropriada para a realidade latino-americana" (Pierucci, 1997, p. 115).

Temos aí, então, um impasse semelhante àquele encontrado pelos sociólogos Philip S. Gorski e Ates Altınordu (2008), quando decidiram arrolar, de um lado, as ponderações do pesquisador Steve Bruce e, do outro, as reflexões de Rodney Stark. Bruce fixa o paradigma da secularização como aquele que indica e pressupõe a derrocada gradativa do poder, da popularidade e do prestígio das crenças religiosas. Com essa definição radical de secularização, o autor vai além e diz não haver razão para esperar que o declínio da religião seja revertido no futuro (Bruce, 2002). Pior ainda, para Bruce, seria afirmar que a secularização já está em retrocesso no presente momento, ou mesmo que se trata de um fenômeno que nunca ocorreu. Na outra extremidade, lá está Stark a escrever que a tese da secularização se sustenta, há quase três séculos, em olhares deturpados a respeito da situação passada e atual das práticas de fé. Daí se explica a celebração do autor ao proclamar que já é hora de levar a tese para o "túmulo das teorias falhas", e que ali ela "descanse em paz" (Stark, 1999, p. 270).

Com a presença de Stark e Bruce em polos opostos da arena, restou a Gorski e a Altınordu sugerirem uma saída engenhosa para essa sinuca de bico. A estratégia, já defendida por Christian Smith (2003), implica que se lide com a categoria "secularização" a partir da sua observação enquanto uma variável analítica. Melhor 
explicando, a proposta é a de que se defina a secularização de um modo particular para um projeto em particular, e que se use essa definição nos moldes de um tipoideal. Estabelece-se, em um primeiro momento, por facilidades heurísticas, o conceito de secularização enquanto recurso investigativo, sem entrar nas possíveis e muitas problematizações em relação às quais a definição pode ser contrastada quando no campo do real. Essa astúcia envolve que se reconheça explicitamente os vários e contraditórios usos nos quais o conceito tem sido colocado e que se renuncie à pretensão de estabelecer um sentido correto e irrevogável.

Raymond Aron mostra que os tipos ideais implicam a identificação e organização de relações inteligíveis próprias a uma sequência de acontecimentos. Trata-se da tentativa de tornar compreensível a confusão da vida real, o que pode ser feito pela localização de sua racionalidade interna, e mesmo pela construção dessa racionalidade "a partir de uma matéria ainda meio informe" (Aron, 2002, p. 756). Há elementos de estilização nos tipos ideais pelos quais o pesquisador procura "tornar inteligível até o limite o que não o foi” (ibid., p. 757). Desse modo, o tipo ideal se configura, conscientemente, como um olhar parcial para uma embaralhada realidade global. Seleciona-se, em determinada realidade caótica, certos traços típicos, procurando constituir, assim, uma abstração que seja racionalmente acessível. Logo, não é a existência "autêntica", o todo complexo, que é abarcado pelo recurso ao tipo ideal.

Daí fazer sentido quando se diz que essa reconstrução estilizada e racionalizante, o tipo ideal, representa não o fim da análise sociológica, mas um meio. É “simplesmente um recurso técnico" (Weber, 1979, p. 372):

O que compete ao trabalho histórico é determinar, em cada caso particular, o quanto a realidade se aproxima ou se afasta desse quadro ideal [...]. [O tipo ideal] Não significa outra coisa senão um conceito-limite [...] com o qual se mede a realidade (Weber, 1965, p. 181) . $^{5}$

\footnotetext{
${ }^{5}$ Excerto traduzido por Sergio Bath.
} 
Como lembra Aron, a nomenclatura "sistema capitalista", por exemplo, utilizada para designar determinado fato histórico, não passa da reconstrução límpida e inteligível de certa realidade múltipla, intrincada e, no mais das vezes, obscura: "O capitalismo nunca é tão claro como nos conceitos dos sociólogos, e estaríamos errados se os criticássemos por isso" (Aron, 2002, p. 757). Desse modo, com a oportunidade de falar em secularização enquanto uma categoria de tipo ideal, parece adequado ponderar que a adoção desse recurso tão somente permite ao pesquisador comparar a realidade com o modelo criado.

Além dessas vantagens investigativas, a escolha pelo tipo ideal como instrumento analítico, no caso desta pesquisa, oferece a oportunidade de recortar com nitidez o sentido que se pretende aqui conferir à expressão "conservadorismo católico". Esse delineamento pode ser obtido na medida em que se trabalha com uma tipologia dos contrários. Inclinar-se-á à exploração de conceitos polares. Tratase de visualizar o jogo dialético entre secularização e conservadorismo católico, os quais serão vistos aqui como portadores de valores antagônicos. Um par que carrega duas éticas opostas. Não custa repetir, parafraseando Sérgio Buarque de Holanda (2010, p. 44), que secularização e conservadorismo católico participam de múltiplas combinações no mundo social e é evidente que, em estado puro, nenhum dos dois possui existência fora do universo das ideias. E uma vez que os tipos se interpenetram na realidade empírica, é necessário defini-los com rigor. Exatamente pela realidade já ser demasiada confusa, é preciso se achegar a ela com conceitos claros. Resta, então, fixar aquilo que é distintivo de cada um dos dois modelos que vão auxiliar na investigação das dinâmicas religiosas que compuseram o caso do PNDH-3.

\section{Secularização estatal versus conservadorismo católico}

A socióloga francesa especializada no estudo do catolicismo em seu país, Danièle Hervieu-Léger, lembra que a gênese e desenvolvimento das sociedades modernas (Hervieu-Léger, 2003, p. 2) implicaram construção de um perfil antropológico pautado pela autonomia pessoal. Daí se seguiu, como resultado cultural histórico, uma ética fundada na inflexão radical sobre a subjetividade. Desse 
fundamento moral resultou, por sua vez, a implementação daqueles direitos humanos inalienáveis, que se desenvolveriam rompendo com os princípios católicos (Poulat, 1986, p. 28), dado que para o cristianismo toda liberdade é um dom de Deus; não é um bem inerente ao indivíduo e não é fonte de direitos (Rosado-Nunes, 2008a, p. 71). De um lado, estabeleceu-se o suposto de um "direito individual a abandonar a fé" e, do outro, inversamente, colocou-se o privilégio dos clérigos, como os únicos guardiões dos tesouros espirituais, de, no limite, impor a crença verdadeira valendo-se da legislação (Curran, 2002), posto que "a liberdade consiste em poder viver mais facilmente conforme as prescrições da lei eterna, com o auxílio das leis civis" aponta ainda uma contradição "infindável e, talvez, insuperável" de ideários (op. cit., p.28), contradição que se expressa recorrentemente por estratagemas de intervenção eclesiástica no âmbito político-legal.

É possível ponderar, todavia, que essa belicosidade entre Igreja Católica e Estado moderno, analisada por Hervieu-Léger e Poulat, de fato ocorre no caso da França, país dos autores e onde o estabelecimento dos poderes republicanos se deu e se dá de forma bastante drástica e agressiva para com a religião. Já no Brasil, meandros históricos impediriam de enxergar tal vigor nos golpes e contragolpes propalados de lado a lado por forças católicas e laicas. Além do mais, no caso nacional não se insurgiria essa incompatibilidade entre a esfera clerical e o âmbito político moderno. Paula Montero, por exemplo, assim como os antropólogos Émerson Giumbelli e Joanildo Burity (cf. Giumbelli, 2008 e Burity, 2001a), chega a sublinhar a relevância da Igreja na definição da laicidade na conjuntura brasileira. A instituição eclesiástica teria operado, simbólica e materialmente, na construção de um modelo nacional de república laica (Montero, 2012).

Já se sabe, entretanto, que a intenção deste item é a de construir tipos ideais. Sabe-se também que o tipo ideal é um instrumento analítico que funciona como um parâmetro de comparação: "fornece um caso limitativo com o qual os fenômenos concretos podem ser contrastados". Mesmo que o cenário social brasileiro seja perpassado e complexificado pelas mais diversas sinuosidades, cabe ao conceito

6 LEÃO XIII, papa (1888). "Carta Encíclica Libertas Praestantissimum”. Disponível em: http://www.fsspxbrasil.com.br/page\%2006-7-Libertas.htm. Data da divulgação: 21/09/2009. Acesso em 30/05/2013 
ideal proceder com "uma simplificação e generalização da realidade". Dessa forma, não obstante o fato de Hervieu-Léger e Poulat trabalharem com a conjuntura francesa, um país aparentemente mais "preto no branco" no que diz respeito às relações entre religião e política, ainda assim as conclusões desses autores são bemvindas, mesmo que para a análise de um episódio que se inclui no tortuoso caso brasileiro, uma vez que possibilitam certas simplificações que são de bom tom neste ponto desta pesquisa.

Antes, porém, é proveitoso que o este investigador se apodere, novamente, de algumas deduções weberianas. Convém lembrar, em particular, que Weber chama de tipos ideais mais de uma espécie de conceitos. Para não me alongar nessas distinções, indo direto ao ponto, a espécie de tipos ideais que importa neste momento é aquela que Aron nomeia de "tipo ideal de indivíduos históricos globais e singulares" (Aron, 2002, p. 758). Para melhor compreensão, retomar-se-á a ilustração dada acima, aquela do capitalismo como tipo ideal. Nesse caso, trata-se da reconstrução inteligível de certa realidade histórica global e singular: global dado que um regime econômico, tomado em seu conjunto, é nomeado de capitalismo; singular porque, para Weber, o capitalismo só teria se efetivado nas sociedades modernas ocidentais. A mesmíssima coisa poderia ser dita a respeito de quando o autor fala em processo de secularização. Também nesse caso trata-se de um tipo ideal de indivíduo histórico global e singular: na concepção weberiana, os poderes temporais se desvinculariam das leis sagradas e tal processo, tomado em sua totalidade e no longo prazo, ou seja, visto de modo global, seria característico e singular à modernidade ocidental.

Da mesma forma, continuando com o modelo ideal de capitalismo como parâmetro, assim como as economias de mercado diferem fortemente da imagem tipificada desse sistema econômico - por exemplo, os mercados muitas vezes acabam por ser progressivamente controlados por oligopólios, em vez de se pautarem pela concorrência da livre iniciativa -, igualmente, é inverossímil que exista, exceto na cabeça do pesquisador, alguma secularização "pura", que não seja atravessada por diversos revezes.

Tento em conta essas ressalvas, já é o momento de definir com justeza o que significa, para esta análise, o termo "secularização" e seus correlatos. No caso, remeter-se-á a expressão à sua provável acepção original, ao sentido que foi dado ao 
vocábulo ainda nos seus primórdios. O filósofo Giacomo Marramao procura mostrar que a palavra surgiu nos tempos da Reforma, "originalmente em âmbito jurídico para indicar a expropriação de bens eclesiásticos em favor dos príncipes ou das igrejas nacionais reformadas" (Marramao, 1983, p. 29) ${ }^{7}$. Pierucci também diz algo bastante semelhante: "A primeira vez que a palavra secularização foi enunciada fora dos muros e dos textos da Igreja Católica [...] foi para nomear o processo jurídicopolítico de desapropriação dos bens eclesiásticos em favor dos poderes seculares" (Pierucci, 1998, p. 66). É com esse sentido primeiro que se caminhará daqui para frente. Mais especificamente, o conceito de secularização recobre, nesta investigação, as relações institucionais entre religião e poder público. Isto é, toda vez que se fizer uso do conceito, a ênfase estará toda ela na secularização do aparato estatal. Com a utilização da categoria, o que se tem em vista é operacionalizar a avaliação sobre a independência (ou não) do Estado em relação a normatividades de viés transcendental e sagrado.

Não há razão para, novamente, alongar a descrição daquela que Pierucci designa como a "secularização que importa em primeiro lugar". Tal pormenorização foi feita exaustivamente em partes anteriores deste capítulo. De toda forma, já deve estar claro, pelo parágrafo acima, que o foco está colocado sobre essa secularização, "a que importa em primeiro lugar", à qual se referirá deste ponto em diante. Sucintamente falando, a atenção estará dirigida para a dessacralização do direito formal, que não é outra coisa senão uma autonomização do ordenamento jurídico, à qual se segue o despontamento do Estado moderno como domínio que não se ampara numa legitimidade de matriz teológica. A secularização que nos é relevante é a que coloca em cheque a possibilidade do poder político justificar a legalidade de suas ações a partir de discursos de feitio hierocrático.

Cumpre informar ainda que, uma vez que "o conceito de secularização, quando referido especificamente ao processo de secularização do Estado, do ensino, da política, da esfera jurídica [...], nada perde em precisão em relação ao de laicidade" (Mariano, 2011, pp. 245 e 246), essas categorias, secularização ou laicidade, serão tomadas a partir daqui enquanto substantivos análogos.

\footnotetext{
${ }^{7}$ Excerto traduzido por Antônio Flávio Pierucci.
} 
Feita a definição do que aqui se entende por secularização, caminha-se à frente para a definição do conservadorismo católico. Trata-se de um esquema antitético: assim como um dos atos causais primeiros da modernização de uma comunidade nacional se encontra na secularização do poder público (Pierucci, 1998 e 2008a), decidiu-se na pesquisa adjetivar dado catolicismo como conservador se e na medida em que ele incorrer no ataque a esse princípio, isto é, toda vez que setores da Igreja Católica se manifestam/arem em oposição ativa à legitimidade do Estado laico. O conservadorismo que interessa para a análise é aquele preocupado em barrar as liberdades contemporâneas só viabilizadas para todos e cada um com avanços na racionalização política de direito e de fato.

Hervieu-Léger diz que a modernidade de uma sociedade pode ser estimada pela valorização que é concedida ao arbítrio individual (Hervieu-Léger, 1999, p.299). Além disso, a mesma modernidade, aponta a autora, implica também o "empoderamento" dos membros cidadãos da coletividade para que tenham condições de definir articuladamente os rumos do corpo social no qual se incluem (ibid., p.298). Em contrário, o conservadorismo eclesiástico, segundo o concebemos, constitui a negação ativa de tais possibilidades abertas de autonomia. E isso nos dois sentidos citados por Hervieu-Léger: no que diz respeito à direção das existências particulares e no que toca aos direcionamentos da coletividade. A oposição à autonomia nas esferas privada e pública, por sua vez, apresenta-se como nãoreconhecimento de uma legitimidade garantida constitucionalmente. Esse desmerecimento eclesiástico de direitos emancipatórios assegurados pela constituição secular deriva, em continuidade, da rejeição a toda "autoridade mundana não submissa ao poder espiritual"8. Sinteticamente falando, o que consideramos como conservadora é aquela posição que contraria o poder público laico por meio da não aceitação de sua legalidade enquanto desvinculada do aparato doutrinal e institucional católico - "Devem todos os governantes atender à soberania suprema de Jesus Cristo e na ordenação temporal nada dispor que impeça a difusão do Reinado Social do Divino Salvador. Pelo contrário, incumbe-lhes facilitar a atividade da Igreja de Deus" (Pio X, 2005, p. 264).

\footnotetext{
${ }^{8}$ Bonifácio VIII, Papa. "Bula Unam Sanctam" (1302). Disponível em: http://www.newadvent.org/library/docs_bo08us.htm. Data da divulgação: 14/05/2007. Acesso em 30/05/2013.
} 
Tal ideário se expressa ainda na declaração de um dos principais líderes leigos da Canção Nova. Em entrevista qualitativa para esta pesquisa, tal liderança disse a respeito do PNDH-3: "esse nefasto programa (...) quer impor ao país uma ideologia que destrói os valores e os conceitos sagrados de nossa sociedade cristã, edificados ao longo de séculos. (...) Como muitos bispos disseram (...), o governo deveria preservar nossas raízes católicas, mas destrói a nossa cultura”.

Talvez uma ilustração retirada da polêmica desencadeada pelo $3^{\circ}$ Programa Nacional facilite o exercício de categorização em andamento: segundo a definição aqui esboçada, um determinado grupo católico não recebe automaticamente a designação de conservador ao simplesmente apresentar, por exemplo, uma postura de oposição à legalização da interrupção voluntária da gravidez. Para que tivesse suas práticas e discursos classificados como conservadores, tal grupo teria de justificar os seus posicionamentos a partir de uma legitimidade fundamentada teologicamente. Fazendo um exercício imaginativo, é possível supor que o grupo católico do exemplo seja contrário à descriminalização do aborto por motivações éticas que não sejam nem um pouco escoradas em razões de ordem sagrada.

Por outro lado, é igualmente factível presumir que o grupo encontre razões para sua postura "pró-vida" a partir de palavras dos versículos bíblicos ou com base nos ditames do magistério eclesiástico. Isto é, os fiéis seriam contra o aborto, por exemplo, porque a sua divindade teria dito na escritura sacra que "antes do seu nascimento, quando você ainda estava na barriga da sua mãe, eu o escolhi" (Jeremias 1:5). A partir da soberania do texto fundamental da religião, esses indivíduos acreditariam firmemente que a existência se inicia na concepção e que, consequentemente, o aborto deva ser proibido, pois se configura um homicídio. Mesmo nessa conjuntura, dá para supor uma situação em que não haveria conservadorismo católico. O grupo religioso, numa ocorrência hipotética, ao procurar barrar a legalização da prática abortiva, pode tentar traduzir suas preocupações teológico-dogmáticas em valores laicos e republicanos. Ao adentrar a arena política para fazer valer seus ideais, os católicos podem respaldar sua posição, fundada em argumentos de ordem divina, com dados obtidos, por exemplo, pela ciência moderna. Ainda que a razão elementar para a proibição do aborto seja porque Deus se revelou contrário a esse procedimento pecaminoso, ainda assim se legitimaria a sua criminalização a partir de informações advindas de campos não 
teológicos do conhecimento, como, quiçá, a embriologia humana. Nesse caso, estaria demonstrado um apreço ou no mínimo uma acomodação à laicidade do Estado liberal moderno, o qual por definição entrava as ações religiosas que, desejosas de estabelecer seus preceitos divinamente revelados, tentam fixar sua doutrina por meio dos poderes Legislativo, Executivo e Judiciário.

Porém, se o grupo católico do exemplo procura eliminar os permissivos para o aborto legal e o faz pela justificativa de que a "lei de Deus" se deva impor sobre qualquer lei humana, daí se faz presente, de fato, o que esta pesquisa define como conservadorismo católico. É próprio do discurso democrático a permissão e a valorização do debate público entre membros atuantes da sociedade civil. Espera-se mesmo que a Igreja Católica, como uma organização civil das mais bem arquitetadas, atue politicamente como porta-voz dos milhões de fiéis que a compõem. O conservadorismo em questão, porém, reclama para si uma autoridade para além da esfera civil, reivindica uma obediência do Estado, um domínio cuja legitimidade não é de natureza política, mas, sim, de raiz sagrada. Para os conservadores, a ação política da Igreja não se deve deixar limitar pelo debate democrático, mas cumpre ser pautada pelo mandato divino, o qual exige que as forças do poder público sejam dispostas em acordo com o estipulado pela instituição eclesiástica. Assentada no fundamento de que "a autoridade temporal deve ser

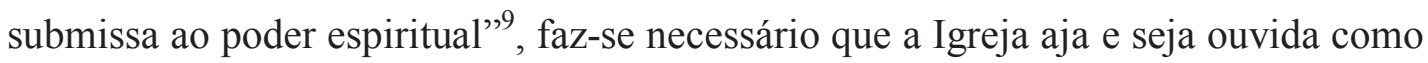
encarregada do "Reinado Social de Cristo":

Desta primeira verdade de fé, a divindade de Nosso Senhor Jesus Cristo, segue-se uma segunda: sua Realeza, e especialmente sua Realeza sobre as sociedades, a obediência que devem ter as sociedades à vontade de Jesus Cristo, a submissão que devem ter as leis civis com respeito à lei de Nosso Senhor Jesus Cristo (Lefebvre, 1991, p. 145).

${ }^{9}$ Idem. 


\section{O argumento episcopal: Do sagrado ao profano}

Esta sessão está fundada na análise dos discursos do episcopado católico ao longo da polêmica do PNDH-3 e também durante a campanha presidencial que transcorreu durante o ano de 2010. Os bispos constituem o topo da hierarquia eclesiástica, de modo que uma investigação a respeito do conteúdo de suas falas pode ser de grande utilidade quando se tem a intenção de explorar as reações institucionais da Igreja ao Programa Nacional. Durante o caso em análise, vários bispos assumiram a sua posição de comando ante os fiéis e muito reagiram diante da enorme periculosidade que enxergaram no decreto. Pela observação das declarações dos religiosos, pôde-se ver que as manifestações tinham seus argumentos dirigidos particularmente para dois eixos principais. De um lado, o episcopado se expunha em contrário à diretriz do Programa que falava em desenvolvimento de mecanismos para impedir que símbolos religiosos continuassem a ser alocados em recintos do poder público. Em paralelo a essa indignação, uma grande quantidade de bispos também se mostrou revoltada com os itens do PNDH-3 que dissertavam sobre a união civil entre homossexuais, a garantia do direito de adoção por casais homoafetivos, a descriminalização do aborto e a concessão de direitos trabalhistas e previdenciários a profissionais do sexo.

Os argumentos do episcopado ao se referirem à proposição do $3^{\circ} \mathrm{PNDH}$ sobre objetos religiosos diferia do raciocínio utilizado para condenar as pautas do decreto que exprimiam recomendações sobre sexualidade, família e reprodução. Observando essa diferença das linhas argumentativas adotadas, fez-se por bem dividir esta sessão em três partes. Na primeira, serão analisadas as palavras dos bispos quanto à retirada de figuras sacras de estabelecimentos estatais. Em seguida, o olhar dirige-se às declarações das lideranças eclesiásticas quanto à promoção, por parte do PNDH-3, de direitos sexuais e reprodutivos. Vale dizer que a separação dos pronunciamentos clericais em dois grupos é feita apenas para uma maior facilidade analítica, haja vista que, na realidade empírica, os anúncios dos religiosos no mais das vezes aglutinavam protestos contra várias das diretrizes do Programa Nacional. Por fim, as reflexões feitas passarão pelo crivo da categoria desenvolvida no capítulo 
anterior, isto é, os conhecimentos adquiridos serão esmiuçados sob a ótica do conceito já delineado de conservadorismo católico.

\section{Entre a metafísica e a cultura, o crucifixo}

A Constituição Dogmática Lumen Gentium, um dos principais textos do Concílio Vaticano II, define uma "Igreja particular" como uma comunidade episcopal (Philips, 1969). Em outras palavras, uma Igreja particular é uma "porção do povo de Deus" que é confiada ao pastoreio de um bispo. Cabendo ao bispo a função de governar uma circunscrição eclesiástica definida, ele atua como a autoridade máxima, em jurisdição e magistério, no interior desse quinhão de Igreja, que pode ser uma diocese, arquidiocese ou prelazia. Dentro de seus domínios, o bispo exerce o que o direito canônico chama de "poder ordinário" (Cân. 381): embora o papa o nomeie e avalie o seu desempenho, e mesmo que existam organismos da Cúria Romana que sirvam para regular o exercício das atividades episcopais, ainda assim, um bispo é relativamente autônomo no trato com seus fiéis. Essa independência administrativa é amparada teologicamente pela compreensão de que o episcopado é o último e supremo grau do sacramento da Ordem - a Ordem é o sacramento que transforma o leigo em diácono, o diácono em sacerdote e o sacerdote em bispo -, o que faz com que os bispos componham a alta hierarquia da Igreja. A isso se soma o fato de o catecismo prezar os bispos como os sucessores dos apóstolos de Jesus (Pio X, 2005, p. 195), o que dá bem a medida da relevância do episcopado no interior da religião católica.

Além da importância concedida ao episcopado pelo direito canônico e pelo catecismo, o prestígio dos bispos para a instituição eclesiástica, no caso do Brasil, é incrementado ainda pela posição de destaque da CNBB junto ao clero. A CNBB é a estrutura que congrega os bispos que atuam no território nacional. Religiosos entrevistados para esta pesquisa são unânimes em apontar a Conferência como a organização que exerce maior influência no interior da Igreja no país. Por meio de suas Comissões Episcopais, Campanhas de Evangelização e Tribunais Eclesiásticos, a CNBB consegue pautar grande parte daquelas que são definidas como as “diretrizes gerais" do clero brasileiro. Esse protagonismo é reforçado ainda pelo fato 
de que a área de atuação da CNBB ultrapassa os limites da Igreja solene; desde a sua fundação na década de 1950, a Conferência foi pensada como um organismo que propiciasse aos bispos um maior canal de expressão política. Fiel a esse ideal, a organização operou, durante o regime militar instalado em 1964, como uma das principais vozes em defesa da promoção dos direitos humanos. Hoje em dia, a CNBB prossegue sendo reconhecida como provavelmente a mais indispensável organização católica presente na esfera pública ${ }^{1}$.

Em resumo, o episcopado ocupa lugar de destaque na Igreja nacional não apenas devido à reverência que é conferida aos "sucessores dos apóstolos" pela doutrina e pelo magistério católicos. Graças à CNBB, os bispos contam com uma organização fortemente estruturada, que lhes possibilita o exercício da liderança prevista pela posição notória que ocupam na hierarquia clerical. Logo, pelo valor que a Igreja dá à corporação dos bispos, parece construtivo que esta pesquisa recorra às falas episcopais como fonte de análise. Esquadrinhando as reações do alto escalão da Igreja ao PNDH-3, procura-se sondar qual é o real influxo do catolicismo conservador nas esferas institucionais eclesiásticas.

Estão destacados, abaixo, enunciados redigidos por bispos, publicados durante a polêmica do $3^{\circ}$ Programa e também ao longo da campanha presidencial que se seguiu. As manifestações reproduzidas apareceram em formato de artigos, notas oficiais e pronunciamentos escritos. Elas visavam derrubar algumas das ações programáticas justapostas no Decreto 7.037, isso quando não tinham por objetivo fazer cair o documento por inteiro ${ }^{2}$. Para efeito de concisão, fez-se necessário selecionar e recortar algumas intervenções religiosas dentre várias que poderiam constar aqui. Um sem-número de declarações clericais motivadas por repúdio ao Programa Nacional, e que intencionavam repará-lo, pululou durante o ano de 2010. O que se viu foi a presença de algumas temáticas reiteradas nas sentenças dos líderes da Igreja. No episódio do PNDH, as indignações católicas corriqueiramente se expressaram a partir de certas pautas, objeções e retóricas bastante semelhantes. São

\footnotetext{
${ }^{1}$ A respeito do tema, conferir o artigo do cardeal Geraldo Majella sobre os 60 anos da CNBB disponível em: http://www.cnbb.org.br/imprensa-1/60-anos-da-cnbb/11127-cardeal-geraldo-majella-e-os-60-anosda-cnbb. Data da publicação: 09/01/2013. Acesso em 03/08/2013.

${ }^{2}$ Cabe sublinhar a quase que total ausência de manifestações episcopais que mostrassem apoio às pautas do PNDH-3. A única exceção foi o fato de que a Comissão Pastoral da Terra, o Conselho Indigenista Missionário, o Movimento de Educação de Base e a Comissão Justiça e Paz de São Paulo, organismos vinculados à $\mathrm{CNBB}$, assinaram a Campanha pela integralidade e implementação do $\mathrm{PNDH}$-3.
} 
esses argumentos empregados repetidamente pelo episcopado que serão investigados neste item.

Esta primeira parte do capítulo evidenciará as reações de líderes da Igreja à proposta do decreto que sugeria o desenvolvimento de mecanismos para frear a ostentação de símbolos religiosos em estabelecimentos públicos da União. $\mathrm{Na}$ prática, a iniciativa do PNDH-3 visava a retirada de crucifixos, sobretudo, de salas plenárias de tribunais e parlamentos. Cumpre lembrar que o Superior Tribunal de Justiça, o Supremo Tribunal Federal, o Senado Federal e a Câmara Federal têm o crucifico afixado em sua sala principal, em posição de destaque, nas suas paredes. Vale ressaltar ainda a inexistência de dispositivos normativos, regimentais ou administrativos, que determinem a exposição do crucifixo ou de qualquer outro símbolo católico em recintos do poder público. Dito isso, resta ver as palavras de dom Orani João Tempesta, arcebispo do Rio de Janeiro, em artigo escrito em janeiro de 2010 sobre aquele que ele nomeou "o plano da intolerância":

Entre tantos acontecimentos intolerantes em todos os cantos do mundo, um deles foi simbólico: no início deste milênio, em março de 2001, foi destruída uma das maiores estátuas de Buda em pé já esculpidas pelo homem. Ficava no vale do Bamiyan, a $240 \mathrm{~km}$ de Cabul, no Afeganistão, e era do século $V$ da era Cristã. Era também declarada como patrimônio da humanidade pela UNESCO. [...] Em nosso país, infelizmente, há certa confusão com relação ao "Plano Nacional de Direitos Humanos" [...] não posso aceitar a ideia que passam com relação ao que significa a justa laicidade do Estado. [...] Um país laico é aquele que respeita todas as religiões e sabe também acolher a cultura de seu povo. [...] Ora, a laicidade do Estado não pode ser sinônimo de intolerância para com a cultura em que se formou e se desenvolveu o Brasil e para com os símbolos que fazem parte de nossa história. [...] Trata-se, antes de 
tudo, de uma questão de preservação da memória [...] e das raízes culturais da nossa identidade brasileira ${ }^{3}$.

No mês seguinte à declaração de dom Tempesta, dom Dadeus Grings, então arcebispo de Porto Alegre, resolveu entrar na polêmica por uma via semelhante à do seu colega do Rio de Janeiro:

Nossa República Federativa apresenta três instâncias, que a Constituição define como independentes e quer harmoniosas: Executivo, Legislativo e Judiciário. Infelizmente, chegamos a uma situação paradoxal em que o Executivo legisla por decretos e medidas provisórias [...] Compete ao Legislativo legislar. [...] Além do mais, o Decreto 7.037 confunde Estado e sociedade. O Estado procura abafar a sociedade. A sociedade, ao contrário do Estado, é pluralista e tem cultura que conquistou ao longo de sua história. [...] lembremos a destruição de uma das maiores estátuas de Buda, esculpida em pedra, no século $V$. Pois, em 2001, iniciando o Novo Milênio, os "donos do poder" no Afeganistão julgaram não poder tolerar esta "idolatria" [...]. Não podemos impunemente despir o Brasil de seus valores religiosos e culturais, a título de equipará-lo aos países de outras tradições. Temos que lutar pelo que é nosso ${ }^{4}$.

Nos dias que antecederam o artigo de dom Grings, já havia sido divulgado um pronunciamento contrário ao PNDH-3 assinado por mais de quarenta bispos e propagado oficialmente por várias arquidioceses:

\footnotetext{
3 A íntegra do artigo de dom Tempesta está disponível em: http://www.zenit.org/pt/articles/o-plano-daintolerancia. Data da publicação: 15/01/2010. Acesso em 20/03/2014.

${ }^{4}$ A íntegra da manifestação de dom Grings está disponível em: http://www.acidigital.com/noticias/pndhconfunde-estado-e-sociedade-e-busca-despir-o-brasil-de-seus-valores-religiosos-e-culturais-afirmaarcebispo-de-porto-alegre-30755/. Data da publicação: 13/02/2010. Acesso em 20/03/2014.
} 


\section{[...] prosseguindo a tradição profética da Igreja Católica no} Brasil que, nos momentos mais significativos da história de nosso País, sempre se manifestou em favor da democracia, dos legítimos direitos humanos e do bem comum da sociedade, [...] nos vemos no dever de manifestar publicamente nossa rejeição a determinados pontos deste Programa. [...] Os símbolos religiosos expressam a alma do povo brasileiro e são manifestação das raízes históricas cristãs que ninguém tem o direito de cancelar ${ }^{5}$.

As três citações se inserem num rol bastante amplo de manifestações que, contrárias à retirada de símbolos religiosos de recintos estatais, argumentam no sentido de apelar às raízes do país. Nessa trincheira contra o PNDH-3, bispos católicos anunciaram o seu receio de que a identidade nacional pudesse estar perigosamente em risco de dissolução. Estaria em curso uma marcha de exclusão dos fundamentos culturais que pautaram o processo de formação do Brasil, sendo o $3^{0}$ Programa mais um passo adiante nesse processo. Numa parte que não foi destacada de seu artigo acima, dom Tempesta fala da estima que cultiva por certa comunidade do Pará que, contrariando a globalização, é capaz de preservar suas músicas, danças, festejos e até seus sotaques. Para o arcebispo do Rio de Janeiro, haveria ali, no norte do país, um povo que saberia guardar a pureza da verdadeira brasilidade. Dom Grings, por sua vez, em seu texto já citado, postula que o paradigma da globalização está ultrapassado e que "hoje o paradigma tende a proteger os valores particulares e as tradições próprias". Quanto a às "tradições próprias", o episcopado que protestou contra o PNDH-3 invariavelmente as localiza no âmbito do religioso.

Religioso, sim, e católico, mais especificamente. Assim se caracteriza o arcabouço cultural brasileiro na visão dos bispos envolvidos na polêmica em questão. Já o inimigo da vez é a lógica da globalização, que tenderia a relativizar as

\footnotetext{
${ }^{5}$ A íntegra do pronunciamento episcopal está disponível em: http://oglobo.globo.com/pais/noblat/posts/2010/02/02/dom-eugenio-sales-protesta-contra-programa-delula-262864.asp. Data da publicação: 02/02/2010. Acesso em 20/03/2014.
} 
raízes cristãs, para o episcopado, definidoras e sustentadoras deste país. Burity enumera, dentre as manobras de resistência à globalização avançada, a idealização da existência de uma unidade local; isto é, forja-se uma identidade coletiva tendo em vista neutralizar a contínua redefinição das regras e cenários que é decorrente do multiculturalismo (Burity, 2001b). Para lidar com uma contemporaneidade na qual as referências de orientação no mundo, antes relativamente estáveis, se fragilizam e se tornam insuficientes, para reestabilizar o espaço coletivo e assim permitir uma movimentação previsível no tecido social, enfim, para colocar as coisas nos seus devidos lugares, recorre-se a uma uniformidade cultural que atenda pelo nome de nação. Na luta pela permanência de objetos católicos em espaços públicos, o argumento da Igreja, na voz do episcopado, é o de que esses "símbolos religiosos expressam alma do povo brasileiro", como diz o pronunciamento assinado por dezenas de bispos.

O crítico literário João Cezar de Castro Rocha reflete que a nação é "um significante vazio ao qual se atribui uma carga semântica segundo as diferentes necessidades geradas pela contingência das circunstâncias históricas" (Rocha, 2003, p. 21). Haveria uma apropriação utilitária do conceito de pátria, cujo conteúdo obedeceria às necessidades do momento. No caso dos bispos, a urgência em fazer cair a proposta de retirada de símbolos religiosos fez com que se atribuísse ao país a "carga semântica" de uma nação católica por natureza. Constrói-se a representação de um Brasil que carrega sempre, em seu íntimo, a fidelidade à Igreja. Desse modo, diversidades e embates culturais que atravessam o território nacional são relativizados ao se figurar uma imagem de perfil essencialista do que constitui a "identidade verdadeira da pátria". Faz-se, desse modo, uma "invenção de tradição" (Cf. Hobsbawn, 1984) em que o passado e o presente nacionais, atravessados por variadas referências e valores, são unificados numa só presença católica. Ao referirse aos símbolos clericais como os "os símbolos da cultura que berçou (sic) e construiu a nossa história", o episcopado postula o catolicismo como uma espécie de metacultura que abarca as heterogeneidades que perpassam o território brasileiro. Essa incorporação da multiplicidade no interior de um núcleo católico leva à minoração da diversidade cultural ao absolutizar as referências católicas.

Dom Tempesta defende que os crucifixos em recintos estatais estão aí por exprimir o caráter real do país: "É como se fosse o DNA de nossa civilização: 99\% 
dos genes são comuns a todos nós. As diferenças são mínimas e quase nem se notam". O arcebispo afirma, assim, com todas as letras, a ideia de que haveria uma uniformidade religiosa a perpassar o território brasileiro de cabo a rabo. A liderança eclesiástica não leva em conta os dados demográficos que apontam para a queda contínua e cada vez mais expressivas no número de cidadãos que se declaram católicos. O IBGE (Instituto Brasileiro de Geografia e Estatística) aponta que o declínio começou de certa forma tímido: em 1940, o Instituto apurava o número de 95\% para o percentual de católicos no Brasil; no decênio seguinte, esse número caiu para 93,7\%; no ano de 1960, os católicos eram 93,1\% do total da população; em 1970, 91,1\% dos brasileiros se declaravam católicos; uma década depois, esse número passava para 89,2\% e, em 1991, diminuiu para 83,3\%. Com o início do novo milênio, vieram os declives vertiginosos: em 2000, a porcentagem dos que se declaravam católicos diminuiu em quase $10 \%$ e foi parar em $73,6 \%$ da população nacional; o mesmo padrão de queda continuou uma década depois, quando se chegou às estatísticas atuais de 64,6\% de católicos em cerca de 190 milhões de brasileiros. Pela primeira vez, o número absoluto dos adeptos do catolicismo diminuiu, transitando de 125,5 milhões de indivíduos em 2000 para 123,3 milhões em 2010. Uma perda de 2,2 milhões de fiéis no mesmo período em que a população do país teve um aumento de mais de 20 milhões. Quando se constatam essas informações do IBGE e se as colocam em contraste com as falas do episcopado, daí se vê nitidamente, no discurso católico, a estratégia que o filósofo Ernesto Laclau classifica como homogeneização de uma "massa heterogênea" (Laclau, 2011, p. 202). Há claro descompasso entre os dados censitários, que revelam um cenário religioso cada vez mais plural, e as palavras dos bispos, que procuram idealizar uma identidade católica que uniria o povo brasileiro como um todo.

Nesse exercício de pensar com o auxílio de dados demográficos, é interessante notar ainda o crescimento vertiginoso do número de evangélicos no país. No ano de 2000, aproximadamente 26,2 milhões se diziam evangélicos, o que constituía 15,4\% da população. Em 2010, os evangélicos passaram a ser 42,3 milhões, ou 22,2\% dos brasileiros. Um aumento de 61,45\% em 10 anos. Tais dados despertam atenção aqui, na medida em que líderes de confissões evangélicas se manifestam muitas vezes discriminados pela exibição de imagens católicas em repartições públicas, assim como criticam, por exemplo, o feriado oficial de 12 de 
outubro e as capelanias nas Forças Armadas (Ranquetat Júnior, 2012, p. 77). Desse modo, por trás da imagem de um Brasil em que todos são harmonicamente irmanados pelo catolicismo, há, sim, lutas encarniçadas entre uma religião cada vez menos majoritária e suas concorrentes em ascensão. E o que não falar do recrudescimento das disputas políticas encabeçadas por militantes de organizações LGBT, feministas, republicanos, marxistas, enfim, toda a sorte de gente que se manifestou, pelas mais diversas razões, em favor da retirada de crucifixos dos espações da União? O "politeísmo de valores" e a multiplicidade de bandeiras reivindicativas prefiguram uma realidade social que escapa à ideia de que, no maior país católico do mundo, haja "um só rebanho e um só pastor”.

$\mathrm{O}$ caso do PNDH-3 indica que quando as lideranças eclesiásticas atuais propõem essa associação entre identidade e localismo, elas o fazem mais sob a égide do nacionalismo e da tradição e menos a partir de um amparo teológico. Esse ponto é importante, de modo que cabe ser esmiuçado. Talvez a observação do discurso de um antecessor de dom Tempesta facilite o entendimento do que está sendo dito aqui. Dom Sebastião Leme, arcebispo do Rio de Janeiro nas décadas de 1920 e 1930, foi o principal idealizador do monumento feito em honra ao Cristo Redentor, assentado no topo do morro do Corcovado, na capital fluminense. Em 11 de outubro de 1931, um dia antes da abertura oficial da estátua, houve o encerramento do Congresso do Cristo Redentor. Na declaração que marcou o final do Congresso, dom Leme assim falou:

Nós queremos que Ele Reine sobre o Brasil. E Cristo reinará! [...] Amanhã eles irão sagrar a Cristo Rei do Brasil. Ó pátria, ajoelhe-se junto a Cruz do Redentor, junto à cruz onde nasceste grande e cresceste imensa. Brasil! Ó pátria, ajoelhe-se junto a Cruz do Redentor. Ó Pátria, conserva-te de joelhos diante de Cristo Redentor porque assim poderás apresentar-se de pé diante das outras nações, 
adorando um só Cristo Redentor [...]. Cristo vence, Cristo reina, Cristo impera ${ }^{6}$.

Previamente a esse discurso, em 1916, ao tomar posse da arquidiocese de Olinda, dom Leme redigira uma Carta Pastoral que visava saudar os seus novos diocesanos. Ainda que voltado aos fiéis da cidade pernambucana, o documento manifestava a intenção de abarcar territórios para além de suas circunscrições municipais:

Desconhecendo ainda as circunstâncias locais de nossa arquidiocese, queremos tratar daquilo que no Brasil de hoje mais necessário se nos afigura. [...] católicos não são os princípios e os órgãos da nossa vida política. Não é católica a lei que nos rege. Da nossa fé prescindem os depositários da autoridade. Leigas são nossas escolas; leigo, o ensino. Na força armada da República, não se cuida da Religião. Enfim, na engrenagem do Brasil oficial não vemos uma só manifestação de vida católica. O mesmo se pode dizer de todos os ramos da vida pública (Leme, 1916, p. 18).

A partir de 1921, com a transferência de dom Leme para o Rio de Janeiro, capital federal, a Carta Pastoral passou a ser efetivada como um programa de ação dos bispos católicos, válido para todo o país. A relevância da Carta pode ser medida pelo fato de que, mais de duas décadas após sua divulgação, o padre Ascânio Brandão ainda afirmava que a ela era "a Carta Pastoral do Brasil" (Azzi; Grijp, 2008, p. 12). Já a revista $A$ Ordem, maior publicação da imprensa católica na época, publicava trechos da Carta nos seus números, sempre antecedidos com a sugestão: "palavras que devem ser dez, vinte, cem vezes meditadas"7. De fato, o escrito de

\footnotetext{
${ }^{6}$ A íntegra do Discurso de Encerramento do Congresso do Cristo Redentor pode ser lida no site da Congregação Mariana Nossa Senhora Auxiliadora e São José: http://salvemariaauxiliadora.blogspot.com.br/2013/10/discurso-de-encerramento-do-congresso.html. Data da publicação: 27/10/2013. Acesso em 14/03/2014.

${ }^{7}$ A Ordem. Rio de Janeiro, n.4, ano I, 1921.
} 
dom Leme foi o documento que mais inspirou e propulsou as orientações eclesiásticas no Brasil até o período que antecedeu a abertura do Concílio Vaticano II. E quais eram as implicações de ter essa carta do arcebispo, também chamada de um "clarim de guerra, de guerra santa" (Santo Rosário, 1962, p. 61), como o principal documento do episcopado durante quatro décadas? Para uma melhor análise das declarações do clero na polêmica do PNDH-3, será proveitosa uma resposta detida a essa indagação.

Para o cientista político Scott Mainwaring, a Carta Pastoral de dom Leme deu início a uma nova era na trajetória da Igreja no Brasil e ao período que pesquisadores chamam de "neocristandade" (Mainwaring, 1989, p. 41). Já na visão dos historiadores Riolando Azzi e Klaus Van Der Grijp, o tempo da neocristandade começou com a mudança de dom Leme para terras cariocas (Azzi; Grijp, 2008, p. 12). De todo modo, seja por um marco temporal ou pelo outro, por aí se vê o influxo da figura de dom Leme no cenário eclesiástico brasileiro da primeira metade do século XX (o Concílio Vaticano II, que, informalmente, "encerrou" a neocristandade, teve seu início em 1962). A neocristandade foi um projeto católico, encabeçado principalmente por bispos, que tinha por objetivo a ressacralização da sociedade: "de fato, a proposta do episcopado era transformar o Estado republicano num Estado religioso" (ibid., p. 13). A laicidade do Estado brasileiro era observada por grande parcela do clero nacional como uma afronta à Igreja. Tal é o que se vê quando dom Leme fala sobre a possibilidade das escolas públicas adotarem formalmente o ensino laico: "Ensino neutro quer dizer não confessional, ensino que não professa religião alguma. Ora, se é sem religião alguma é anti-religioso" (Leme, 1916, p. 91). Em outra ocasião, o sacerdote voltou a afirmar que "laicismo, neutralidade, irreligião e ateísmo são termos que na prática se equivalem" (Leme apud Azzi; Grijp, 2008, p. 12). Jackson de Figueiredo, intelectual convertido por Leme à causa da neocristandade, escreve, em continuidade, que "a Igreja só será respeitada num tal país [...] quando a Nação [...] souber ser politicamente uma nação católica. Para isto é preciso organizar-se, é preciso lutar, só delegar poderes a quem viva com ela na Fé em Jesus Cristo". ${ }^{\circ}$

O objetivo dessas declarações era tentar garantir que a doutrina do catolicismo fosse reconhecida pelo Estado como única fonte de orientação moral

\footnotetext{
${ }^{8}$ Idem.
} 
permitida ao povo brasileiro. Dentro desse princípio, era obrigatória a eliminação, do âmbito nacional, de crenças alternativas às determinações da Igreja. Dom Leme mostra preocupação, por exemplo, com a religião kardecista, que se mostrava em ascensão: “com mágoa assistimos à invasão ameaçadora do espiritismo, ao qual, sempre ávido de maravilhas, se filia o povo" (Leme, 1916, p. 47). Caberia ao poder público a repressão contra o espiritismo, mesmo que tal medida fosse proibida pela Constituição vigente; como diz o redator da revista eclesiástica Vozes: "[que] a polícia fiscalize esse movimento, fechando todas as portas para um desenvolvimento maior [...]. Não nos iludamos, o espiritismo [...] não merece as regalias que a constituição outorga"”.

No Brasil, o direito de cidadania deveria ser exclusivo à fé católica apostólica romana, com ênfase no "romana": contra o estado laico, os líderes da neocristandade queriam que Santa Sé pudesse atuar soberanamente no território nacional. A Cúria de Roma era quem deveria orientar com exclusividade a prática religiosa dos cidadãos, cabendo ao governo proibir o culto público de outras crenças, devendo, inclusive, interditar manifestações religiosas do catolicismo popular que não passassem pelo "modelo do Vaticano" (Cf. Azzi; Grijp, 2008, p. 17). Essa diretriz doutrinal e ética única deveria provir dos papas, os quais apoiavam essa tentativa de imposição por parte dos bispos brasileiros. Mainwaring mostra que, até 1965, os pontífices consideravam oficialmente a separação legal entre Igreja e Estado como uma heresia da modernidade (Mainwaring, 1989, p. 42). Desse modo, não é de estranhar que os superiores máximos da Igreja aplaudissem abertamente Dom Leme em sua militância por um catolicismo mais vigoroso, que se imiscuísse nas principais instituições governamentais. Com dizia Pio X, era preciso "restaurar tudo em Cristo". E na luta dos bispos brasileiros para fazer valer as palavras do papa, o monumento do Cristo Redentor entrava como peça-chave.

Voltando à solenidade de inauguração da estátua, cabe observar algumas manchetes que se revezaram nas capas de jornais e revistas quando da inauguração da obra: "Christo Rei"10, "majestoso monumento"11, "majestoso e soberbo"12,

\footnotetext{
${ }^{9}$ Vozes. Rio de Janeiro, Nov/1942, p. 322.

${ }^{10}$ O Malho, 17.10.1931.

${ }^{11}$ Diário da Noite, 02.10.1931.

12 Idem.
} 
"figura excelsa de Jesus" com "a magnitude daqueles braços abertos"13. As reportagens, por sua vez, falavam sobre o monumento em termos como "tão grande, tão majestoso, tão sublime"14, "Ele é o sol, e tudo mais é satélite"15, entre outras metáforas que concediam ao Cristo os atributos de soberania e majestade. Quando se observa qual era a imagem que o episcopado brasileiro queria passar com o projeto do Redentor, logo se vê que as qualificações dadas pela imprensa não foram à toa. A teologia e a arte sacra do período colonial enfocavam, como objeto de devoção, principalmente o Cristo Sofredor e o Bom Jesus, remetendo, assim, à figura do Jesus humilde e pobre. Já a neocristandade tem pela figura do Cristo Rei um especial apreço. O Cristo Rei é o "Cristo glorioso": "Ele domina de mar a mar, e desde o rio até as extremidades da terra. Todos os reis da terra $\mathrm{O}$ adoram e os povos todos $\mathrm{O}$ servem" ${ }^{16}$. Trata-se de um símbolo de triunfo. A historiadora Lucia Grinberg mostra que o Cristo Redentor foi construído com base em figuras do Cristo Rei e é daí, dessa imagem de realeza, que se tira aquela que Grinberg vê como a maior originalidade do monumento: ao representar o Cristo em forma de cruz sem estar na cruz, sem estar crucificado ou sofredor, mas olhando a todos circunspectamente, de cima, escapa-se da imagem tradicional de Jesus sacrificado no drama do calvário (Grinberg, 1999). O monumento do Redentor retrata o Cristo soberano, não o humilhado.

O Cristo Redentor representa o Cristo Rei, o qual, por sua vez, é o maior emblema de um paradigma de ação. Em 1925, Pio XI instituiu, na primeira encíclica de seu pontificado, a festa litúrgica em honra ao Cristo Rei. O objetivo declarado era fazer o mundo prostrar-se diante de Jesus, ele, sim, o real soberano do Universo. Como está declarado nos acréscimos feitos ao Terceiro catecismo da doutrina cristã, a Festa de Nosso Senhor Jesus Cristo Rei foi instituída pelo papa com a intenção de

Combater o laicismo que afasta os homens e a sociedade da obediência a Deus e à sua Igreja e [que] não reconhece nenhuma realeza de Jesus Cristo neste mundo. [...] Santificamos a festa de Nosso Senhor Jesus Cristo Rei [...]

\footnotetext{
${ }^{13}$ Fon-Fon, 10.10.1931.

${ }^{14}$ Fon-Fon, 17.10.1931.

${ }^{15}$ O Malho, n.1504, ano XXX.

${ }^{16}$ Missal Quotidiano. Salvador, Editora Beneditina, 1960.
} 
renovando o firme propósito de nos empenharmos para que a legislação do país e a vida familiar e social se conformem com a Santa Lei de Deus. Está no âmbito deste propósito combater o divórcio, a legalização do aborto e toda e qualquer ordenação [...] que é contrária aos desígnios de Deus sobre o convívio dos homens (Pio X, 2005, p. 256).

Prescreve-se a todos o culto de Cristo Rei como um "remédio eficaz à peste que corrói a sociedade humana", sendo que a maior miséria contemporânea seria o "erro grosseiro [de] denegar a Cristo Homem a soberania sobre as coisas temporais todas" (Pio XI, 1950, p. 11). A exaltação ao Cristo Rei foi instituída pelas autoridades do Vaticano para combater a laicidade, e foi com esse mesmo propósito que os bispos brasileiros erigiram o Cristo Redentor (Grinberg, 1999, p. 61). O monumento foi concebido como uma estatuária sacra, mas com o objetivo de abarcar um público largamente superior ao dos frequentadores de altares e oratórios. A escala do Redentor, sua visibilidade e inscrição na paisagem da metrópole tinham por objetivo atingir um público muito maior do que o dos paroquianos. O Cristo foi situado no cume do Corcovado para impor-se à vista de toda a coletividade, afinal

seu império não abrange tão só as nações católicas ou os cristãos batizados [...] estende-se igualmente e sem exceções aos homens todos, mesmo alheios à fé cristã, de modo que o império de Cristo Jesus abarca, em todo rigor da verdade, o gênero humano inteiro(Pio XI, 1950, p. 12).

O influente padre Assis Memória dizia que, com o monumento do Redentor, "a cordilheira colossal [o corcovado] é um prolongamento da Palestina. Sim. A Serra do Mar passa a ser uma continuação das montanhas da Judéia”. O Rio de Janeiro transfigurado em terra santa: "O Cristo que não dorme [...] guarda esta terra que é sua, por direito de nascimento e de conquista" ${ }^{17}$.

${ }^{17}$ O Malho, n.1504, ano XXX. 
Continuando a celebrar o monumento carioca, o padre Assis Memória afirma que se trata de "um símbolo verdadeiro a desmentir um outro símbolo negativo: $\mathrm{O}$ Cristo dos Andes é sempre o Cristo da Liberdade, em desmentido solene àquela estátua que também olha para o oceano às portas catedralescas da metrópole newyorkina" (apud ibid., p. 62). Desde seus primórdios, o Cristo Redentor foi pensado em paralelo com a Estátua da Liberdade norte-americana. Construiu-se uma batalha de alegorias e uma disputa de significados de liberdade: ao símbolo da liberdade republicana, a estátua da Liberdade, é contraposta a "verdadeira" liberdade, que é o Cristo; liberdade política, democrática, ou a remissão dos pecados, a redenção da alma (idem). Com a neocristandade, desejava-se que o Estado se aliasse à Igreja na difusão às massas de valores católicos. A obra do Corcovado, construída conjuntamente com dinheiro público e eclesiástico, foi, no país, o maior símbolo (literalmente) do desejo teocrático de que, com "o domínio temporal, $[. .$.$] a realeza do nosso Redentor abrace a totalidade dos homens" (Pio XI,$ 1950, p. 12).

É interessante voltar agora às declarações de dom Tempesta sobre o PNDH3, principalmente à parte em que ele remete ao próprio Cristo Redentor:

A estátua do Cristo Redentor, que, do cume do Corcovado, a 710 metros de altura, ergue-se como uma maravilha do mundo moderno [...] é um símbolo não só do Rio de Janeiro, mas do Brasil.

No mesmo artigo, o arcebispo diz:

A cultura cristã e católica integra a história de nosso país. Não tem como se negar a história, embora em muitos ambientes queira (sic) reinterpretá-la esvaziando-a dos verdadeiros valores nos quais se baseia nossa identidade. Em nosso atestado de batismo está uma Missa celebrada no alvorecer do Brasil, Terra de Santa Cruz! Temos nomes de 
cidades, ruas, locais e até mesmo em nossa bandeira ideias e símbolos ligados a diversos grupos que fazem parte de nossa história nacional. [...]

Qualquer pessoa ao chegar a um país e ver os seus monumentos e seus símbolos logo se depara com a sua realidade cultural, humana e religiosa. [...] Nestes dias estamos vivenciando a preparação para a festa de São Sebastião, devoção trazida há 445 anos por Estácio de Sá para a cidade de São Sebastião do Rio de Janeiro. Teríamos como contar a história da cidade maravilhosa sem esses dados? Aliás, é só pesquisar a história da maioria de nossas cidades para ver onde estão as fontes e as inspirações.

Pensando especificamente sobre a problemática dos crucifixos em recintos estatais, Tempesta traz à tona a questão do Redentor, por considerar que se trata igualmente de um "símbolo religioso em espaço público". E como o arcebispo enxerga o monumento? A estátua não é abordada pelo sacerdote como uma obra feita para lembrar que a realeza de Deus é soberana sobre as "coisas temporais". Para Tempesta, não se trata de uma obra que soleniza uma verdade teológica. Distancia-se, dessa forma, do objetivo para o qual a estátua fora pensada em suas origens. Em 1931, o Cristo Redentor foi inaugurado para exibir a todos que, na nação brasileira, a "cidade de Deus" seria honrada em sua altivez perante a "cidade dos homens". Ao separar-se das concepções da neocristandade sobre o Redentor, dom Tempesta adotou a visão do monumento menos como um objeto sacrossanto e mais como uma referência cultural. E ao aproximar o Cristo Redentor dos crucifixos situados em recintos estatais, o arcebispo procura mostrar que esses crucifixos são, também eles, menos símbolos de significado metafísico e mais objetos que remetem à história e à formação da nação.

Gilmar Mendes, juiz do Supremo Tribunal Federal, também fez um raciocínio semelhante em outro caso tão polêmico quanto o do PNDH-3. Na votação sobre a legalidade ou não da interrupção da gravidez em casos de fetos anencéfalos, 
Mendes, em seu discurso, procurou se distanciar das posições que qualificou de "antirreligiosas":

Recentemente, acompanhava o célebre caso dos crucifixos e ficava preocupado com esse tipo de desenvolvimento. Talvez daqui a pouco tenhamos a supressão do Natal do nosso calendário ou a revisão do calendário gregoriano. Ou alguma figura inspirada vai pedir a demolição do Cristo Redentor $^{18}$.

Já dom Dimas Barbosa, secretário-geral da CNBB, ainda durante as repercussões derivadas do $3^{\circ}$ Programa Nacional, afirmou que:

Daqui a pouco vamos ter que demolir a estátua do Cristo Redentor, no morro do Corcovado, que ultrapassou a questão religiosa e virou símbolo de uma cidade. Impedir a presença desses símbolos é uma intolerância muito grande. É desconhecer o espírito cristão e religioso da tradição brasileira $^{19}$.

As falas dos dois bispos e a do juiz do STF seguem a mesma trajetória em três passos: sustentam, primeiro, que a presença da estátua do Cristo Redentor sobre o Corcovado "ultrapassou a questão religiosa" para se tornar um marco cultural; em seguida, aproximam essa presença do Redentor aos crucifixos em recintos estatais, pela via argumentativa de que todos eles são "símbolos [religiosos] em espaços públicos"; finalmente, afirmam que se a decisão for pela retirada dos crucifixos, que se abra mão também do monumento que está no Corcovado. Dado que essa decisão

\footnotetext{
${ }^{18}$ A fala inteira de Gilmar Mendes está disponível em: http://oglobo.globo.com/brasil/stf-vota-favor-doaborto-de-anencefalos-com-placar-de-8-2-4624458. Data da publicação: 14/04/2012. Acesso em 25/04/2014.

19 As palavras de dom Dimas estão disponíveis em: http://oglobo.globo.com/politica/com-regras-paratodos-os-lados-texto-do-programa-nacional-de-direitos-humanos-recebe-criticas-3072042. Data da publicação: 08/01/2010. Acesso em 27/04/2014.
} 
seria absurda, logo também seria um disparate recolher os crucifixos de recintos estatais.

A “arma da cultura” (Mafra, 2011) é acionada por católicos, para defender a presença de símbolos religiosos em recintos públicos. Os crucifixos não representariam os dogmas de uma confissão específica, e por isso poderiam conviver harmoniosamente com o estado laico. A propósito, resta lembrar que, para escândalo de dom Leme - para quem, "fora da Igreja não há salvação" -, seu sucessor, dom Tempesta, assim como dom Dadeus Grings, comparou a retirada de crucifixos com o ato, perpetrado pelo governo afegão, de destruir uma estátua budista do século V. Essa aproximação inter-religiosa e culturalista evidencia de forma patente um afastamento em relação aos modelos discursivos e aos parâmetros da neocristandade. Entretanto, antes de ensaiar qualquer afirmação mais conclusiva a esse respeito, há de se examinar como o episcopado manifestou sua contrariedade em relação a outras diretrizes do $3^{\circ}$ Programa Nacional.

\section{Lei divina, lei natural e sexualidade}

Foucault concebia suas obras como não mais do que caixas de ferramentas, às quais os leitores poderiam recorrer em busca do instrumental que os auxiliasse a pensar: "Eu não escrevo para um público, escrevo para usuários, não para leitores" (Foucault, 1994, p. 524) ${ }^{20}$. Este segundo item será pautado, em grande parte, pela apropriação de conceitos foucaultianos, para uso "utilitário" na análise em andamento. Observar-se-ão algumas possibilidades que a obra de Foucault nos fornece para uma "história do presente" sobre os atuais posicionamentos das lideranças eclesiásticas, especificamente no que concerne aos chamados direitos sexuais e reprodutivos. De início, faz-se necessário retomar a distinção que o autor expõe entre o que ele chama de código moral, de um lado, e o que é classificável como moralidade de comportamento, por outro. O primeiro diz respeito, muito resumidamente, a um conjunto de regras de ação propostas por intermédio de aparelhos prescritivos diversos (família, escola, igreja, por exemplo) (Foucault, 2012, p. 33), sejam tais regras sistemática ou difusamente formuladas. A moralidade

\footnotetext{
${ }^{20}$ Tradução do excerto feita por Ingrid Müller Xavier (Castro, 2009, p. 5).
} 
de comportamento, por sua vez, refere-se à atuação efetiva dos indivíduos em relação a tal código, o qual é explícita ou implicitamente apresentado pelos aparelhos prescritivos (Ibid., p. 34).

Resta ainda, porém, o componente da moralidade sobre o qual Foucault se debruça, por ele nomeado de ética, que corresponde ao modo pelo qual o sujeito forma a si mesmo enquanto sujeito de moralidade. Dado um código de ação, e para determinados tipos de ação, existem diferentes maneiras de conduzir-se, não simplesmente como agente, mas como sujeito moral dessa ação. E aqui cabe diferenciar quatro elementos: 1- A substância ética: a parte do indivíduo que constitui a matéria da conduta ascética. Por exemplo, uma mesma exigência ao nível do código, a fidelidade, pode endereçar a substâncias éticas distintas: aos atos ou aos desejos. 2- Os modos de sujeição: o modo conforme o qual o indivíduo estabelece relação com a regra moral e se vê entrelaçado a ela: a fidelidade pode ser praticada pelo pertencimento a um grupo em que tal regra é valorizada ou porque se considera individualmente que a regulação responde às necessidades de nobreza em uma bela vida. 3- As formas de elaboração do trabalho ético: a austeridade sexual pode ser praticada, por exemplo, por meio de um longo trabalho de aprendizagem e cálculo ou por uma renúncia súbita aos desejos. 4- A teleologia do sujeito moral: uma ação moral visa à constituição de uma conduta moral característica de um sujeito moral. A fidelidade conjugal, cumpre ilustrar, pode dizer respeito a uma conduta moral que procure a tranquilidade perfeita da alma, ou pode tender a uma purificação que assegure a salvação após a morte:

Não existe ação moral particular que não se refira à unidade de uma conduta moral; nem conduta moral que não implique a constituição de si mesmo como sujeito moral; nem tampouco constituição do sujeito moral sem 'modos de subjetivação', sem uma 'ascética' ou sem 'práticas de si' que as apoiem. A ação moral é indissociável dessas formas de atividade sobre si, formas essas que não são menos diferentes de uma moral a outra do que os sistemas de valores, regras e de interdições (ibid., p. 37). 
São essas formas de subjetivação moral, mais especificamente as suas permanências e descontinuidades ao longo da história, que interessam a Foucault. A relevância de tal historicização ética ou ascética, por sua vez, é evidenciada quando o foco recai nas diferenças entre a moralidade da Antiguidade e a do cristianismo. Em contramão a Nietzsche (1992), Foucault argumenta que a relação entre a moral cristã e a moral antiga não é simplesmente uma relação de oposição, em que o cristianismo representa uma cultura de austeridade (monogamia, abstenção, virgindade) e o paganismo, uma cultura permissiva. Focando primeiro o nível dos códigos morais de comportamento, a rigor o que se observa são notáveis semelhanças entre a Antiguidade e o cristianismo.

Tanto em uma quanto no outro, encontra-se conteúdos discursivos que atribuem imagem negativa às relações homossexuais. Além disso, há nos dois discursos uma preocupação, até medo, quanto aos efeitos do dispêndio sexual sobre a saúde individual. E valorizam, ambos, a fidelidade conjugal e a abstinência (Foucault, 2012, p. 21). O que gera um forte contraste entre essas duas culturas, no entanto, é o modo como esses ideais são integrados em relação ao sujeito e o sentido que lhes é atribuído. O cristianismo faz valer uma moral cujos preceitos são constritivos e universais (ainda que se pesem as prescrições relativas ao status dos indivíduos). Em compensação, no pensamento antigo, as exigências de austeridade não são organizadas em uma moral coerente, autoritária e imposta uniformemente; são antes uma exceção e uma distinção em relação à moral corrente (ibid., p. 29), dizendo respeito à constituição de si enquanto "sujeito moral" (Idem, p. 28) ${ }^{21}$. Vão para muito além das delimitações que as grandes interdições civis ou religiosas podiam traçar na Antiguidade. Trata-se de uma reflexão moral que não se dirige com referência a interdições lembradas nos códigos, costumes ou prescrições de caráter geral. Essa é uma moral pensada com exclusividade por e para uma minoria de homens livres.

\footnotetext{
21 A constituição de si enquanto "sujeito moral", para Foucault, diz respeito à circunscrição, pelo indivíduo, da "parte dele mesmo que constitui o objeto dessa prática moral, [definição de] sua posição em relação ao preceito que respeita, [estabelecimento para si] de um certo modo de ser que valerá como realização moral dele mesmo; e, para tal, age sobre si mesmo, procura conhecer-se, controla-se, põe-se à prova, aperfeiçoa-se, transforma-se" (Foucault, 2012, p. 28).
} 
A moral da Antiguidade trata das condutas em que homens devem fazer uso de sua autoridade e superioridade: na renúncia à prática de prazeres que não são condenados costumeiramente; na fidelidade numa vida de casamento em que nenhuma regra geral os impede de terem relações extraconjugais; na abstenção de se ter relações com rapazes, relações estas que, dentro de certos limites, são admitidas ou até valorizadas pelo conjunto geral da população. As austeridades sexuais na Grécia Antiga não se expressam enquanto interdições explícitas para o comportamento dos indivíduos, mas sim enquanto elaboração e estilização de uma bela vida, em que se deixa para os outros lembranças de uma existência distinta e primorosa (ibid., p. 31). Seu domínio não é o da religião nem o dos sistemas legais, é sim o da relação de cada um consigo mesmo: a escolha de conferir beleza moral à própria vida.

Em contrapartida, a moral cristã funciona não sobre uma escolha, mas sobre a submissão. O modo de subjetivação não é mais uma estética de vida, mas a subordinação a uma ordem divina, com a prevalência das regras sobre a constituição de si. No cristianismo, a ascese apresenta-se enquanto mortificação de si no transcurso da vida terrena. Não se trata mais de ser senhor de si mesmo, de possui-se e gozar da posse de si. Trata-se da renúncia de si (Foucault, 1994, p. 717). Na antiguidade, a problemática da liberdade, entendida como não escravidão, encontrase no cerne do cuidado de si: não ser escravo de suas paixões. Já para o pensamento cristão, o que há sobremaneira é a ideia de obediência, entendida enquanto morte cotidiana para este mundo. Se para os gregos, o autocontrole é um meio para alcançar domínio e poder sobre si, no cristianismo, é a obediência à lei moral que se transfigura em virtude que se sobressai (ibid., p. 145).

O que salta aos olhos quando se observam as reações ao PNDH-3 provindas de lideranças católicas é a utilidade investigativa que uma pluralidade de conceitos foucaultianos pode ter para a análise da atitude eclesiástica atual em relação à sexualidade. Numa genealogia dos discursos clericais, é possível fazer uso, com grande proveito, das classificações que Foucault utiliza fartamente em seus estudos sobre os jogos de verdade na relação de si para consigo na Antiguidade Clássica. Para que uma análise desse feitio possa ser desenvolvida, reproduzem-se a seguir, tal 
como foi feito no item anterior, respostas escritas por bispos católicos em razão da divulgação do $3^{\circ}$ Programa Nacional.

Em março de 2010, o arcebispo de Belo Horizonte, dom Walmor Oliveira de Azevedo, redigiu um artigo sucinto especificamente sobre o PNDH-3. O escrito deveria ser divulgado aos fiéis da capital mineira e foi permanentemente fixado no departamento de comunicação da arquidiocese. Abaixo, estão reproduzidas duas partes do curto texto:

\begin{abstract}
[O aborto] É uma gravidade que remete ao confronto com exigências éticas fundamentais, aquelas que, em última instância, têm a força de iluminar, regular e substituir as opções legislativas e políticas que são, incontestavelmente, contrárias a princípios e valores inegociáveis. [...] $E^{\prime}$ lamentável que entendimentos errôneos da laicidade estejam comprometendo o respeito a verdades resultantes do conhecimento e do direito natural ${ }^{22}$.
\end{abstract}

Pouco mais de dois meses após a carta de dom Walmor, veio a manifestação eclesiástica que mais gerou repercussão durante o caso do PNDH. Trata-se da declaração da $48^{\mathrm{a}}$ Assembleia Geral da CNBB. Como já foi dito no primeiro capítulo, o pronunciamento foi tornado público após passar por votação em que participaram bispos de todo o território brasileiro. Nesse escrutínio, mais de $90 \%$ do episcopado, num total de 248 presentes, votaram a favor da divulgação das palavras assinadas por dom Geraldo Lyrio Rocha, dom Luiz Soares Vieira e dom Dimas Lara Barbosa, que eram, na época, respectivamente, o presidente da CNBB, o vicepresidente da CNBB e o secretário-geral da entidade:

\footnotetext{
${ }^{22}$ Artigo assinado pelo Arcebispo Metropolitano de Belo Horizonte, Dom Walmor Oliveira de Azevedo, a respeito do PNDH-3. Data da publicação: 05/03/2010. Disponível em: http://www.arquidiocesebh.org.br/site/artigoArcebispo.php?id_artigoArcebispo=503. Acesso em 20/04/2014.
} 
É oportuno lembrar aqui a luta empreendida pelos Bispos do Brasil em favor da redemocratização do País e sua ação efetiva contra o arbitrio e a tortura. [...] Quando a Igreja se pronuncia sobre os Programas Nacionais de Direitos Humanos, ela o faz com o propósito de exercer o seu direito de sujeito presente na sociedade e participante dos destinos de nosso povo. [...] [A linha do PNDH-3] é reveladora de uma antropologia reducionista que está na base de certas formulações nas quais pretensos direitos são incluídos entre os Direitos Humanos [...]. Só uma visão integral de pessoa humana pode fundamentar corretamente os Direitos Humanos. Tais direitos estão baseados na lei natural inscrita no coração do homem e presente nas diversas culturas e civilizações [...] não se deve permitir que esta ampla variedade de pontos de vista obscureça o fato de que não só os direitos são universais, mas também o é a pessoa humana, sujeito destes direitos ${ }^{23}$.

Já durante as eleições presidenciais de 2010, quando a questão do aborto não saía de cena, dom Cristiano Jakob Krapf, bispo emérito, foi um dos muitos líderes da Igreja que procuraram alertar os paroquianos sobre as proposições do PNDH-3:

[...] existe uma lei anterior a mandamentos religiosos e leis civis positivas, a lei inscrita no coração do ser humano, a lei natural acessível à consciência de cada pessoa. [...] Num mundo pluralista fica difícil argumentar com mandamentos de Deus e falar de pecados. Ninguém quer ser chamado de pecador, nem mesmo aquele que diz que não existe pecado. Resta apelar à lei natural, à lei interior da consciência. O

\footnotetext{
23 A declaração da $48^{\mathrm{a}}$ Assembleia Geral da CNBB está disponível em: http://www.cnbb.org.br/imprensa-1/sala-de-imprensa/notas-e-declaracoes-3/3342-3o-programa-nacionalde-direitos-humanos-pndh-3. Data da publicação: 15/05/2010. Acesso em 23/05/2014.
} 
problema é que para isso faz falta um sólido fundamento filosófico ${ }^{24}$.

Há continuidade entre os discursos religiosos acima no que diz respeito à ênfase posta em referências provenientes do que se convencionou chamar de jusnaturalismo. Também conhecida como teoria do direito natural ou teoria da lei natural, a corrente jusnaturalista da filosofia do direito afirma a existência de princípios morais universais que a razão seria capaz de discernir por trás de variações ocasionais de regras e costumes (Cf. Strauss, 2009). Antes de qualquer normatividade social, a consciência preexistente na inteligência do ser humano the permitiria avaliar objetivamente o correto e o incorreto, distinguindo um do outro. Desse modo, as regras jurídicas impostas pelo Estado poderiam amparar-se na faculdade da mente racional de conhecer as coisas como elas de fato são. $\mathrm{O}$ direito natural daria embasamento ético e seria anterior ao direito posto pelo Estado.

Weber enxerga o direito natural como sucessor da norma de origem sagrada: "forma específica, e a única consequente, de legitimidade de um direito que possa permanecer quando se suprimem as revelações religiosas e a sacralidade autoritária da tradição e de seus portadores" (Weber, 1969, p. 640) ${ }^{25}$. Já Catherine ColliotThélèle diz que, uma vez enfraquecidas as inspirações transcendentais e a santidade da tradição, fica o direito natural como única forma de legitimidade restante (Colliot-Thélèle, 1992). A certeza de que, por baixo dos diferentes condicionantes culturais, a inteligência poderia captar universalmente o que é justo e o que é injusto: tal convicção jusnaturalista é o que restaria para dar aura de legitimidade ao âmbito jurídico-político. Com o declínio da autoridade tanto da tradição quanto do carisma, restaria a crença na capacidade da razão de reconhecer o bem e o mal.

Não se entra aqui no mérito do quão questionável pode ser o conteúdo desse "racionalismo otimista" (Ignatieff, 2000, p. 211), o qual descarta a presença de diferentes "regimes de verdade" pela crença de que a lei natural conta com princípios gerais impressos na consciência de todos os indivíduos. Pierucci

\footnotetext{
24 artigo de Dom Cristiano Jakob Krapf se encontra disponível em: http://www.cnbb.org.br/articulistas/dom-cristiano-jakob-krapf/4935-pecadores-precisam-de-leis. Data da publicação: 14/10/2010. Acesso em 23/05/2014.

${ }^{25}$ Tradução do excerto feita por Antônio Flávio Pierucci.
} 
reconhece que há, sim, uma "aura quase da ordem do supra-sensível" nas concepções jusnaturalistas (Pierucci, 1998, p. 59). De todo modo, ele próprio aponta o jusnaturalismo como a "única forma de legitimidade axiologicamente fundada ainda disponível numa sociedade dessacralizada" (idem).

Essa sucessão da norma religiosa para o direito natural é o que parece ocorrer nos discursos católicos sobre sexo, família e reprodução. Assim como no item anterior, voltar-se-á às falas de sacerdotes do período da neocristandade para melhor observar esse ponto. Em 1933, os jesuítas da revista Mensageiros do Coração de Jesus listavam os três principais causadores da destruição da unidade familiar: a limitação artificial da natalidade, a autorização do casamento civil independente do matrimônio religioso e a permissão legal do divórcio. Na intenção de fazer o Estado impedir essas "três pragas", os jesuítas tentavam fazer chegar às esferas do poder público o seguinte apelo:

Não é negar a moral católica procurar atentar a destruição da família pela base, impedindo o seu aumento? Não é negar o nome de católico impedir a santificação da família pelo matrimônio cristão, reduzindo o casamento a um simples contrato sem valor? Por fim, introduzir ou aprovar o divórcio a vínculo, sempre condenado pela Igreja? ${ }^{26}$

A respeito da preservação do ambiente familiar tradicional, dom Cabral, arcebispo de Belo Horizonte, nos anos 1930, suplicou, também, aos legisladores, para que contribuíssem com a Igreja para a manutenção da ordem social segundo os preceitos eclesiásticos:

Repor Jesus Cristo na família e na sociedade. Reestabelecer o princípio da autoridade humana como representante da

\footnotetext{
${ }^{26}$ Mensageiro do Coração de Jesus, mar./1993, p. 132.
} 
autoridade de Deus. Colocar a nação ao abrigo das seduções [....] sob uma legislação cristãa ${ }^{27}$.

Em 1941, o ministro da Educação proibiu a entrada no Brasil de livros que falassem favoravelmente a respeito do uso de anticoncepcionais. No contexto dessa interdição, um sacerdote do Piauí instigava os membros de sua paroquia a lutarem pela proibição de qualquer tipo de contraceptivo. A interdição se pautaria pelo fato da Igreja reprovar o controle artificial da natalidade:

[Impugnai] com todas as energias de que fordes capazes, se porventura aparecerem, as teorias ou métodos modernos sobre a natalidade, reprovados pela moral e pela suprema autoridade da Igreja, e em nada conformes com o progresso e civilização de um país católico como o vosso ${ }^{28}$.

Quando faz o paralelo entre as formas de subjetivação da Antiguidade e do cristianismo, Foucault pontua que, na ética cristã a ação moral que desemboca na constituição do sujeito moral está focada na obediência. A subjetivação ocorre pela sujeição à ordem. De fato, verificando as falas dos adeptos da neocristandade e também os escritos dos bispos contemporâneos na conjuntura do PNDH-3, vê-se, igualmente, uma ênfase do discurso católico sobre a urgência de os fiéis se porem sob o código moral apresentado pelo aparelho prescritivo, que no caso é a Igreja. Os códigos morais também continuam relativamente os mesmos: continua-se a falar contra a legalidade do divórcio, os métodos anticoncepcionais permanecem condenados, o casamento gay é seguidamente interditado, entre outras injunções. Da neocristandade até os dias atuais, as substâncias éticas que são objeto dos códigos morais também não mudaram: no que diz respeito à homossexualidade, por exemplo, se continua a dizer que "as pessoas homossexuais são chamadas à castidade". As atrações homossexuais não são necessariamente pecaminosas; o

\footnotetext{
${ }^{27}$ Primeiro Congresso Eucarístico Nacional Brasileiro. Salvador: [s.e.], p. 130.

${ }^{28}$ Revista eclesiástica Brasileira, set./ 1941, p. 604.
} 
pecado está na efetivação do ato sexual. A exigência do código moral, nesse caso, refere-se, como substância ética, aos atos e não aos desejos.

Há, entretanto, um deslocamento, da neocristandade ao clero de hoje, no que diz respeito à fonte de legitimidade que ampara esse código moral. Com foco primeiro no período pré-Concílio Vaticano II, cabe observar que, quando os jesuítas da revista Mensageiros do Coração de Jesus falam sobre a possibilidade de legalização do divórcio, eles invocam que tal coisa não poderia ocorrer pois seria uma medida condenada pela Igreja. O desquite não deveria tornar-se legal porque a dissolução do matrimônio era reprovada pelo magistério católico, o "representante da autoridade de Deus", com toda a gravidade que isso impõe. A neocristandade legitimava o seu código moral pelo argumento de que sua ordem provinha da fonte mais fidedigna que poderia haver, isto é, as regras deveriam ser efetivadas porque descendem da própria divindade. Cumpre dizer que, ainda que a Igreja fosse o aparelho prescritivo e a legitimadora do código moral, o conjunto de regras católicas não deveria abranger apenas os adeptos da religião: "Seu império estende-se aos homens todos, mesmo alheios à fé cristã”. Daí se explica a declaração de dom Leme: "A nós, homens de fé e da Igreja, cabe impor ao mundo a ordem cristã" (Santo Rosário, 1962, p. 53). As análises foucaultianas já haviam comentado que as formas ascéticas da Antiguidade são pensadas para um grupo minoritário de homens, enquanto que no cristianismo é esperado que a coletividade toda aja de acordo com a conduta moral da ascese.

As falas episcopais de hoje, que ressaltam o direito natural, também querem fazer valer as regras eclesiásticas para o conjunto geral da população, não circunscrevendo o seu código moral especificamente para os católicos. Porém, diferentemente dos sacerdotes da neocristandade, os bispos que protestam contra o PNDH-3 não tentam legitimar suas ordens pelo argumento de que elas seguem os mandamentos da Igreja, a representante dos Céus. As determinações clericais devem ser acatadas por toda a sociedade porque seguem a lei natural, são expressão da lei “inscrita no coração do homem e presente nas diversas culturas e civilizações". Os sujeitos devem continuar submissos aos códigos do catolicismo, mas essa imposição não se daria mais porque a Igreja de Cristo é soberana sobre a massa; a moralidade de comportamento ditada pelos bispos deve ser estabelecida para o conjunto da 
população porque os religiosos só estão repetindo aqueles princípios morais universais já impressos na consciência de cada pessoa.

Desse modo, a proposta do PNDH-3 que fala em regulamentação da parceria civil entre pessoas do mesmo sexo deve ser rejeitada não por ser contrária às leis divinas, mas porque se opõe ao direito natural. A mesma pecha vale para a diretriz que propõe a garantia do direito de adoção por casais gays. Como declara o arcebispo emérito da arquidiocese de Campo Grande, Dom Vitório Pavanello, "o comportamento homossexual não está de acordo com a lei natural, pois o homem está para a mulher e vice-versa" 29 . Já o padre Paulo Ricardo, um dos mais atuantes sacerdotes das atividades evangelizadoras da Canção Nova, afirma que "a verdade fundamental de que o matrimônio seja algo genuinamente formado por um homem e uma mulher não é, nem nunca foi, de ordem religiosa, mas natural" ${ }^{\prime 30}$. O padre Luis Carlos Lodi, líder do Pró-Vida de Anápolis, associação atuante na luta contra o direito ao aborto, diz que o Programa Nacional quer destruir a regra de que "homens só se casam com mulheres, e mulheres só se casam com homens"31. Reconhecer publicamente outras configurações familiares implicaria em desintegrar a "família natural".

É interessante analiticamente ver o padre Lodi - um dos protagonistas da militância para que não haja permissivos legais ao aborto - na trincheira contra as uniões homoafetivas. No interior do plano que Foucault define como biopolítica, as temáticas do aborto e da homossexualidade realmente se tocam. A questão, em ambos os casos, é quanto ao valor que se dá à reprodução. As lutas pela permanência da ilegalidade do aborto e do casamento gay têm em comum o fato de perpetuarem o biopoder ao afirmarem que a dimensão reprodutiva da sexualidade se impõe sobre a dimensão afetiva (Portella; Ávilla; Ferreira, 2005, p. 11). Entre os motivos apresentados pela Igreja para tentar frear a união civil entre homossexuais, um dos

\footnotetext{
29 A declaração de dom Vitório está disponível em: http://www.midiamax.com.br/noticias/755839dom+vitorio+comportamento+homossexual+nao+esta+acordo+com+lei+natural.html\#.U8cqY7FJ28A. Data da publicação: 03/06/2011. Acesso em 14/06/2014.

30 A afirmação do sacerdote está disponível em: https://padrepauloricardo.org/blog/a-falsidade-docasamento-gay. Data da publicação: 25/04/2013. Acesso em 16/06/2014.

31 A fala do padre está disponível em: http://www.rainhamaria.com.br/Pagina/9880/Padre-Luiz-CarlosLodi-da-Cruz-Desconstrucao-da-heteronormatividade/imprimir=true. Data da publicação: 13/01/2011. Acesso em 16/06/2014.
} 
mais repetidos é o de que o casamento gay seria "intrinsecamente estéril",32. Seria impiedade subverter a principal finalidade do casamento, que é de formar uma prole.

No caso do aborto, a gravidade do ato para a Igreja é ainda maior, pois não só há a interrupção da reprodução, como também se degradaria a natureza que é própria da mulher, a atribuída vocação à maternidade inscrita na constituição da essência feminina. Essa visão afirma que a mulher encontra a sua realização mais íntima no ato de ser mãe. (Rosado-Nunes, 2008). A socióloga Maria José RosadoNunes mostra que diferenças biológicas entre os sexos são constantemente invocadas e validadas pela hierarquia clerical para atribuir o feminino à esfera doméstica (idem). Haveria uma ordem fundada na biologia, de caráter imutável e independente das vontades individuais, que estabeleceria os papéis de cada gênero, cabendo à mulher a vida no lar. O discurso eclesiástico se eterniza, assim, por intermédio de um paradigma que esconde seu caráter histórico e mutável, construindo simbolicamente a fixidez biológica (Bourdieu, 2002). A "intransigência eclesiástica" (Poulat, 1986) reproduz as disposições incorporadas como habitus, naturalizando-as por um processo de desistoricização das divisões sexuais socialmente estabelecidas. O direito ao aborto, contudo, exprime a possibilidade de as mulheres controlarem o seu processo reprodutivo. A interrupção voluntária da gravidez resultaria, assim, numa quebra do "destino biológico" da mulher.

Também a prostituição é condenada por essa mesma chave: a profissionalização do sexo subverte as "qualidades femininas especiais" inscritas na natureza da mulher e que encontram na maternidade a sua plenitude. Além disso, a prostituição seria lastimável por envolver prazeres sexuais sem finalidade procriadora. Dessa forma, quando o PNDH-3 fala em garantia de direitos trabalhistas às profissionais do sexo por meio da regulamentação da profissão, o Programa Nacional rechaça duplamente o que a Igreja reconhece como lei natural. Daí se entende quando a CNBB escreve que o decreto em questão fere a dignidade feminina.

\section{PNDH-3 e a reação católica (não) conservadora}

\footnotetext{
32 A declaração está disponível em: http://www.adf.org.br/home/2013/01/7-razoes-para-se-ser-contra-opseudo-casamento-homossexual/. Data da publicação: 10/01/2013. Acesso em 16/06/2014.
} 
Muitos são os autores (López, 2004; Higuet, 2002) que apontam, neste início de século XXI, estar sendo a imagem da Igreja Católica, a de Roma e a daqui, literalmente capturada pela maior visibilidade e maior influência de alas e tendências ideológicas conservadoras, seja no interior do clero (alto e baixo), seja entre leigos mobilizados. Respirar-se-ia hoje nos meios católicos um clima bem mais oxigenado para tais setores, bem mais favorável a eles, se comparado àquela atmosfera generalizada de "progressismo" (teológico e pastoral) que vigorou relativamente na metade final do século passado. Nas posições que a Igreja toma atualmente neste ou naquele assunto, os conservadores exibiriam um viço recuperado, com pretensões de ortodoxia e laivos de revanchismo.

Essa retomada de conservadorismo, entretanto, seria um processo paulatino que viria das três últimas décadas, configurando-se como evidente nos recuos e reversões operados no papel ativista dos outrora abundantes setores e líderes de esquerda do catolicismo, que atuavam como protagonistas e profetas do futuro na sociedade civil brasileira. De fato, a segunda metade dos anos 1980 e os anos imediatamente subsequentes assistiram à redemocratização político-institucional do país, uma transição lenta e gradual que se valeu como pôde de uma intensa participação social e que reverberou fortemente na restauração da normalidade regimental por causa da reativação democrática de instrumentos de expressão, mediação e representação popular, fossem órgãos estritamente governamentais, fossem simplesmente originários dos âmbitos civis (Carvalho, 2008, p. 197). Com a reorganização e a revitalização pós-abertura de forças sindicais, partidárias, parlamentares e de movimentos sociais identitários não confessionais, a hierarquia eclesiástica brasileira acabou perdendo muito daquela função supletiva, tão necessária em tempos ditatoriais, de porta-voz das massas excluídas de representação na esfera pública (Gill, 1998).

Contudo, não convém situar apenas nas mudanças de conjuntura política, a diminuição das cenas desse "catolicismo progressista". Também influiriam, nesse corte de participação e envolvimento, modificações da própria configuração clerical nacional. Trata-se aqui, particularmente, das novas diretivas eclesiásticas brasileiras, decididas a alterar os sentidos de sua disposição institucional prévia. Nessa mudança de rota, pode-se localizar, entre outras medidas igualmente de retomada ortodoxa, a 
retirada das CEBs do centro da atuação pastoral e o declínio em força retórica do repertório teológico da libertação (Löwi, 2000). No lugar da "opção preferencial pelos pobres", observam-se ênfases estratégicas concentradas, mainstream, na valorização das comunidades emocionais ditas carismáticas e de sua típica espiritualidade sentimentalista (Prandi, 1997), a qual não é voltada para ações políticas de traço reformista.

Esse processo de rupturas institucionais no interior do catolicismo nacional não seria, porém, caso isolado, mas aconteceria em acordo com mudanças de igual teor empreendidas na Sé romana. Cinquenta anos atrás, quando da convocação do Concílio Vaticano II, a proposta era que a Igreja pudesse minimizar, ainda que tardiamente, os atritos vários entre o ideário clerical e o ideário fundador da experiência moderna. O que se constataria hoje, como linha de orientação eclesiástica, estaria longe de um esboço de conciliação do catolicismo com os conteúdos discursivos da contemporaneidade. Desde João Paulo II (cf. HervieuLéger, 1999), as tomadas de posição pastorais estariam muito mais próximas das que comumente caracterizavam os pontífices até a primeira metade do século passado.

Consequentemente, enxergar-se-ia, na cena religiosa contemporânea, um catolicismo pré-conciliar, como se, com o declínio da "Igreja popular" (Mainwaring, 1989, p. 265), houvesse ocorrido um regresso do ethos clerical anterior às renovações promovidas pelo concílio inaugurado por João XXIII. De fato, é possível contemplar retornos sob a alcunha da "hermenêutica da continuidade", que propõe não terem as decisões conciliares iniciadas em 1962 representado, de modo algum, interrupção em relação à mentalidade eclesiástica precedente. Essa perspectiva, que vê o Concílio Vaticano II perfeitamente inserido na tradição milenar da Igreja, foi liturgicamente abençoada com o decreto Summorum Pontificum, o qual autoriza oficialmente o retorno de celebrações de missas em latim, seguindo o antigo ritual instalado pelo Concílio de Trento (1545-1563). O papa Paulo VI promulgou em 1969, ao final do Concílio Vaticano II, um novo rito ordinário para as missas. Com a reintrodução do missal anterior a Paulo VI, foi institucionalmente declarado que o concílio do século XX não inseriu nenhum tipo de descontinuidade na história milenar da Igreja. Além disso, veem-se atualmente importantes sacerdotes, como o monsenhor Brunero Gherardini, cônego da Basílica de São Pedro, em Roma, 
defenderem que o Concílio Vaticano II não fez declarações dogmáticas e que, portanto, seus postulados não teriam de ser obrigatoriamente aceitos.

Contudo, mesmo que, hoje, no interior do catolicismo, haja a relativização das inovações trazidas por João XXIII e Paulo VI, ainda assim, parece complicado falar em um retorno a tempos pré-conciliares. Teólogos mostram que, de fato, em diversos campos doutrinais e pastorais, desde a década de 1980, houve afastamentos paulatinos da instituição eclesiástica em relação às perspectivas do Concílio Vaticano II. Porém, no que diz respeito às relações Estado-Igreja, o episódio do PNDH-3 evidencia as lideranças eclesiásticas adotando um discurso que escapa às falas pré-conciliares. Se o catolicismo anterior ao Concílio Vaticano II tratava oficialmente a laicidade dos poderes temporais como um anátema, o mesmo não se pode dizer dos discursos dos bispos vistos na polêmica em análise. Os posicionamentos religiosos em reação ao $3^{\circ}$ Programa contrariam, assim, as reflexões da socióloga Brenda Carranza, que identifica características nítidas da neocristandade nas expressões mais visíveis do catolicismo nacional contemporâneo: "neocristandade constatada [que] responde a uma postura saudosista daqueles que pretendem governar em nome de Deus e articular-se ancorados no prestígio da igreja" (Carranza, 2000, p. 168).

No caso dos crucifixos em recintos estatais, a posição do episcopado atual, tal como na neocristandade, permanece sendo a de que símbolos católicos devem ser implantados e mantidos em lugares do poder público. Porém, para amparar essa defesa, os religiosos de hoje argumentam que as figuras sacras constituem uma referência essencial na formação da identidade brasileira, de modo que a presença desses objetos seria importante no sentido de resguardar o patrimônio cultural do país. Não se questiona a laicidade do Estado, não se lança mão do catecismo ou das leis de Deus.

Também quando se observam os discursos episcopais relativos às diretrizes sobre sexo e reprodução do Programa Nacional, pode-se dizer que a atuação do clero fugiu aos moldes da neocristandade. O episcopado fez uso da retórica do jusnaturalismo. Argumentos fundados religiosamente rarearam na polêmica. Weber apontava que o direito natural tomaria cada vez mais o lugar da norma especificamente religiosa, isso no quis diz respeito à legitimidade aceita no âmbito jurídico-político. $\mathrm{O}$ autor também escreve que a causa dessa transição seria o 
avançar do processo de secularização (Weber, 1969, p. 604). Igualmente, Pierucci situa o jusnaturalismo como um "fenômeno de secularização" (Pierucci, 1998, p. 59). O trend secularizante é o que explicaria o desprestígio do argumento de origem sacra quando utilizado para fins políticos. Mas no incidente do PNDH-3, como é possível falar em secularização depois das controvérsias que o decreto enfrentou, quando, por pressão da Igreja, fez-se necessário modificar mais de uma pauta do documento? Além disso, será que ainda dá para pensar em termos de secularização após a eleição presidencial de 2010, na qual a religião ditou enorme parte dos debates?

É importante que se compreenda que secularização não implica ausência de participação das religiões nos rumos que tomam poder estatal. A lógica pluralista possibilita uma disparidade de posicionamentos na esfera política, no que se incluem os religiosos. Na sociedade laica, ao menos formalmente, forças ideológicas diversas têm todo o direito de estarem na arena pública. No interior da democracia brasileira, é razoável que a Igreja Católica tenha uma participação consideravelmente atuante, afinal trata-se simplesmente da maior e mais influente organização da sociedade civil nacional.

O que não cabe ao Estado laico é agir com base em motivações de fundo transcendental alegadamente sacrossantas. Numa democracia moderna, as esferas do poder público se veem constitucionalmente impossibilitadas de ceder a invocações da ordem do sagrado (Ávilla; Portella; Ferreira, 2005, p. 11). Quando o episcopado resguarda as suas ações políticas com o léxico do jusnaturalismo, os bispos não fazem outra coisa senão tentar verter as preocupações próprias da sua confissão específica em proposições fundadas em princípios morais que se pretendem universais. Não é pouca coisa. Trata-se da instituição clerical deixando de reivindicar uma autoridade para além da própria sociedade. Como escreveu a CNBB, "quando a Igreja se pronuncia sobre os Programas Nacionais de Direitos Humanos, ela o faz com o propósito de exercer o seu direito de sujeito presente na sociedade". A Igreja, nesse caso, age como membro da esfera civil e não "em nome da competência que lhe foi outorgada pelo direito divino" (Rosado-Nunes, 2008, p.77). Nesse sentido, a participação política de religiosos não contra-evidencia o processo de secularização ou remete a um seu vacilo. Muito pelo contrário: no momento em que o clero se vê na necessidade de participar do debate público e não 
de se impor acima dos embates democráticos, daí se constatam avanços da democracia laica. As palavras de dom Krapf, em artigo já citado, são significativas de uma Igreja que se vê inibida em usar a sua doutrina religiosa para atuar politicamente: "Num mundo pluralista fica difícil argumentar com mandamentos de Deus e falar de pecados. [...] Resta apelar à lei natural, à lei interior da consciência”.

Uma vez que se tem clareza quanto ao exposto acima, vale voltar às interrogações que propulsionam esta investigação. Primeiro, a questão do prestígio do catolicismo conservador no interior da instituição eclesiástica. No episódio do PNDH-3, a Igreja lutou contra a possibilidade de união civil entre homossexuais, fez oposição à adoção de crianças por casais homoafetivos e ainda tentou barrar as advertências que se manifestavam em favor da legalização do aborto e pela concessão de direitos a profissionais do sexo. O clero conseguiu ainda retirar do decreto a pauta que propunha a retirada de símbolos religiosos de recintos do poder público. Para determinado senso comum, essas ações clericais são, no mínimo, indubitavelmente conservadoras, para não dizer que são anacrônicas, tradicionalistas, retrógradas e, quiçá, fundamentalistas. Porém, querendo escapar às definições apressadas, ficou decidido que, na análise, o que pautaria determinada ação católica como conservadora seria o fato dela tentar impor as diretrizes eclesiásticas à coletividade toda por meio do aparato público, recorrendo, para isso, a uma legitimidade divinamente estabelecida e que se imporia sobre todo e qualquer poder estatal. Ou seja, o que define a atividade política como católico-conservadora não é a atividade em si, mas a fonte de legitimidade à qual se recorre para fazer valer a atividade.

Nesse sentido, pode-se dizer que as manifestações das lideranças da Igreja em reação ao PNDH-3 não constituíram atos conservadores. Ao fazer uso de uma legitimidade de viés culturalista - no caso dos objetos religiosos - ou jusnaturalista - no caso das pautas sobre sexo e reprodução -, ficou evidenciado pelo episcopado o declínio do conservadorismo católico. A palavra "declínio" foi utilizada propositalmente para remeter ao fato de que os discursos da neocristandade revelavam, eles sim, tentativas de incutir a fé religiosa nas decisões do poder público. Consequentemente, verifica-se que a Igreja, até um passado recente, se caracterizava em grande parte por influências de viés conservador católico. E o que 
causaria essa transição de um conservadorismo inequívoco para uma situação em que ele quase nem aparece?

Se a passagem do direito religioso para o direito natural é consequência do avançar do processo de secularização, logicamente o mesmo raciocínio vale para a queda de prestígio do conservadorismo católico verificada na Igreja do Brasil. Weber mostra que, com a secularização, argumentos de ordem religiosa perdem força no campo jurídico-político, daí a necessidade de apelar ao jusnaturalismo. O mesmo fator justificaria a escolha dos bispos pela "arma da cultura" na hora de defender que crucifixos continuem instalados em salas plenárias do poder público. Com o Estado laico, a "arma do sagrado" perde em efetividade política. Dessa forma, conclui-se que o conservadorismo católico tem sua influência abatida no âmbito eclesiástico exatamente porque, antes, esse mesmo conservadorismo teve sua influência rebaixada no âmbito estatal. A secularização explica a deslegitimidade do argumento católico-conservador na esfera jurídico-política, e é essa deslegitimidade, por sua vez, que explica o desprestígio do conservadorismo na instituição clerical. O rebaixamento do conservadorismo católico no Estado causa a depreciação do conservadorismo católico na Igreja.

O atual arcebispo do Rio de Janeiro escreve que os formuladores do PNDH-3 não compreenderam qual é a "função do Estado laico" e que o decreto deveria ser rejeitado por violentar a "justa laicidade do Estado". Em vez de opor-se belicamente à neutralidade religiosa do poder público, como o fazia seu predecessor dom Leme, dom Tempesta tenta argumentar exatamente tomando a laicidade como uma conquista que merece toda a consideração. Também dom Walmor de Azevedo lamenta que "entendimentos errôneos da laicidade estejam comprometendo o respeito a verdades resultantes do conhecimento e do direito natural". Ao se declararem abertamente em prol da secularização do Estado, os bispos dão mostra de como o conservadorismo católico está desvalorizado.

Antes de concluir, cumpre fazer um parêntese em prol de um maior cuidado no manejo das evidências coletadas: não dá para dizer que o ideário católicoconservador esteve completamente ausente na polêmica do $3^{\circ}$ Programa. A questão é que ele se fez presente apenas de maneira bastante espaçada, para não dizer periférica. Em todo caso, vale destacar as declarações de um membro do clero que expressou de forma distintamente conservadora o seu repúdio ao PNDH-3. Em 
setembro de 2010, o padre Marcelo Tenório, da arquidiocese de Campo Grande, no Mato Grosso do Sul, redigiu um extenso artigo intitulado "Não ao aborto e aos Herodes de nosso tempo". O texto foi divulgado em meio às eleições, com a intenção de ajudar a rechaçar a candidatura petista à presidência da República:

[...] não podemos eleger com nosso voto pessoas que não se alinham à Lei Suprema e Divina e que defendam posições contra a Lei de Deus, ou mais claramente, contra Deus. Votar em quem é a favor da legalização do aborto, quem defende e promove o reconhecimento da união entre pessoas do mesmo sexo, é colaborar com a paganização do Estado, que jamais pode ser laico, visto que deve ser regido por leis em perfeita harmonia com a Lei Divina Positiva. É o que chamamos de Reinado Social de Nosso Senhor Jesus Cristo. Nos partidos políticos sempre há quem defenda uma moral contrária à moral cristã. Entretanto, nenhum outro assumiu isso publicamente como o PT. Em suas declarações, documentos e práticas, fica bem claro o que ele pensa e para onde ele aponta. [...] no dia 20 de fevereiro de 2010, no seu IV Congresso Nacional, o PT manifestou "apoio incondicional" ao $3^{\circ}$ Programa Nacional de Direitos Humanos [...]. Ensina o Catecismo da Igreja que colaborar com o pecado grave, nem que seja por omissão é comete-lo também. O aborto é pecado grave que brada aos céus por justiça. Votar em qualquer candidato que o apóia é ser réu diante de Deus [...] Defendamos a nossa fé! Defendamos a vida dos inocentes indefesos que está em nossas mãos! Defendamos a Família tão querida por Deus. Não queiramos escutar no dia do nosso julgamento aquelas 
palavras terríveis do Senhor: "Afastai-vos de Mim, vós que praticastes a iniquidade” (Mt 25, 41) ${ }^{33}$.

Foi proveitoso que se trouxesse um longo excerto do artigo para cá na medida em que o texto do padre resume a ortodoxia clerical em sua forma conservadora quase ideal-típica. O sacerdote aduz argumentos sob o resguardo do "Reinado Social de Nosso Senhor Jesus Cristo", ataca com todas as letras o princípio da laicidade do Estado, diz que, contra o PNDH-3, é preciso defender a fé e as leis de Deus. Além disso, o religioso não usa a expressão "família natural", como ficou comum no léxico jusnaturalista do episcopado que criticou o $3^{\circ}$ Programa. O presbítero de Campo Grande prefere o vocábulo "Família tão querida por Deus", a qual deve ser escorada legalmente sob o risco de se cair em "pecado grave" e se tornar culpado diante dos Céus.

A reação do padre Tenório constitui um contraexemplo, um desvio em relação ao constatado nesta pesquisa. De todo modo, é evidente que o discurso do sacerdote não refuta os resultados da análise. O excerto serve apenas para mostrar que as conclusões da investigação não devem ser vistas de maneira unívoca, mas de forma matizada. Ainda é possível identificar, no interior do clero nacional, o conservadorismo católico no sentido rigoroso que aqui se dá ao termo. O que não é grande surpresa, há de se convir, tendo em vista o histórico político brasileiro, com séculos de hegemonia imperial eclesiástica. O que causa espanto, isso sim, é ver como os discursos católico-conservadores passaram, em poucas décadas, da regra à exceção.

\footnotetext{
$33 \mathrm{O}$ texto do sacerdote está disponível em: http://arquidiocesedecampogrande.org.br/arq/formacaoigreja/3401-nao-ao-aborto-e-aos-herodes-de-nosso-tempo-exorta-sacerdote-brasileiro.html. Data da publicação: 19/09/2010. Acesso em 23/07/14.
} 


\section{Considerações finais}

Na época da publicação do PNDH-3 (janeiro de 2010), o Cardeal Geraldo Majella Agnelo era arcebispo de Salvador e arcebispo-primaz do Brasil. Fazendo valer sua posição de direção perante os fiéis católicos, o sacerdote assinou um artigo em oposição ao Programa Nacional pouco após o decreto ser lançado:

O Governo apresentou, no início das férias de final de ano, o Programa Nacional de Direitos Humanos (PNDH) [...] que, segundo muitos comentadores, agride diversos artigos da Constituição Brasileira [...]. $O$ ONDH $\quad$ quer descriminalizar o aborto [...] pretende fazer passar como direito universal a vontade de uma minoria, já que a maioria da população brasileira manifestou explicitamente sua vontade contrária. Fazer aprovar por decreto o que já foi rechaçado repetidas vezes por órgãos legítimos traz à tona métodos autoritários dos quais com muitos sacrifícios nos libertamos ao restabelecer a democracia no Brasil na década de 80.

O PNDH pretende banir do espaço público os símbolos religiosos. Creio que um referendum a respeito disso demonstraria a origem ideológica de uma opção que um pequeno grupo quer impor ao país inteiro, revelando sua postura autoritárial.

A ênfase da intervenção de dom Majella Agnelo é a de que as diretrizes do PNDH-3 a respeito da legalização do aborto e pela retirada de objetos sacros contrariariam as aspirações da maior parcela da população brasileira. É pelo

${ }^{1}$ O Artigo do Arcebispo de Salvador e Primaz do Brasil, Cardeal Geraldo Majella Agnelo, está disponível em: http://www.zenit.org/pt/articles/brasil-programa-de-direitos-humanos-e-osequivocos-para-o-desenvolvimento. Data de publicação: 25/01/2010. Acesso em 28/07/2014. 
princípio da democracia majoritária, em que as decisões políticas precisam ser orientadas pela vontade da maioria, que o decreto deve ser refreado. $\mathrm{O}$ arcebispo apela à "maioria moral" (Duarte, 2013) como fonte de legitimidade das decisões do Estado democrático moderno. Diferencia-se, assim, do argumento eclesiástico da primeira metade do século XX, quando o Cristo Redentor foi erguido não pela premissa de que o Brasil tinha mais de $90 \%$ de seus habitantes adeptos do catolicismo, não em nome do povo predominantemente católico, mas porque o Brasil seria essencialmente católico. Como diz Giumbelli, "A rigor, não se tratava da ideia de maioria, e sim de uma essência: o Brasil como nação constitutivamente católica. [...] celebrava-se a consagração a Cristo, concebido como o representante da nação e o redentor do Estado" (Giumbelli, 2012, p. 48).

A Pastoral de Católicos na Política da Arquidiocese de São Sebastião do Rio de Janeiro e do Leste-1 da CNBB - que congrega todas as dioceses da Província Eclesiástica de São Sebastião do Rio de Janeiro -, em sua nota oficial sobre o PNDH-3, divulgada em abril de 2010, balizou a sua rejeição ao Programa por via semelhante à adotada pelo arcebispo-primaz do Brasil. A objeção é a de que o conteúdo do decreto foi formulado por uma minoria cujos interesses não levam em conta os ideais da maior parte dos cidadãos do Brasil:

O Programa Nacional de Direitos Humanos (PNDH-3) aborda uma temática [...] que não foi submetida a um debate nacional, inclusive desrespeitando a autonomia do Congresso Nacional, agredindo a Constituição Federal e a legislação em vigor. Suscita graves preocupações não apenas pela questão do aborto, do casamento de homossexuais, das adoções de crianças por casais do mesmo sexo, pela proibição de símbolos religiosos nos lugares públicos, pela transformação do ensino religioso em história das religiões, pelo controle da imprensa, a lei da anistia, etc, mas, sobretudo, por uma visão reduzida da pessoa humana. A questão em jogo é principalmente antropológica: [...]não respeita a concepção de vida humana da grande maioria do povo brasileiro. [...] Vida, família, educação, liberdade de 
consciência, de religião e de culto não podem ser definidos pelo poder [...] de uma minoria 2 .

Além de se resguardar na defesa da "concepção de vida humana da grande maioria do povo brasileiro", a Pastoral ainda manifesta que as prerrogativas do PNDH-3 não respeitam a Constituição Federal, a atual legislação e a autonomia do Congresso. Dom Majella Agnelo também declarou o seu receio diante da alegada possibilidade de o decreto atacar artigos do texto constitucional. A propósito, na sessão anterior desta dissertação, vê-se dom Dadeus Grings reclamar que, com o Programa Nacional, o Brasil chega a uma situação em que o Poder Executivo interfere nas instâncias do Legislativo. O PNDH-3 seria uma tentativa do chefe de governo de legislar por decretos e medidas provisórias, desrespeitando a separação de Poderes exigida constitucionalmente. Em todos esses casos, a contestação ao Programa esteve sustentada pela preocupação quanto à inconstitucionalidade dos objetivos do documento.

É a Carta Magna do Brasil que é tomada como referência para aviltar o decreto. Mais especificamente, os bispos postulam que o último PNDH quer violar a separação do Executivo, do Legislativo e do Judiciário, prevista na Constituição. Já no caso das lideranças católicas anteriores ao Concílio Vaticano II, os alvos da depreciação eram os textos constitucionais. Não se tratava de resguardar a autonomia dos três Poderes, mas de garantir a harmonia entre dois poderes (Igreja Católica e Estado brasileiro) (Azzi; Grijp, 2008, p. 195): “o governo temporal [tem que] se amoldar ao espiritual, e mais o favorecer e promover" ${ }^{\prime 3}$. Na neocristandade, o clero criticava a Constituição por sua neutralidade religiosa, chegando a propor que se transgredisse a Carta da República uma vez que ela permitia o culto público de outras crenças. Na conjuntura atual, o episcopado adota a Constituição como uma referência que legitima as suas ações políticas.

Na valorização do texto constitucional, o arcebispo-primaz do Brasil delineia uma aproximação das medidas do PNDH-3 com as arbitrariedades perpetradas pelo

\footnotetext{
2 Anota oficial da Pastoral de Católicos na Política da Arquidiocese de São Sebastião do Rio de Janeiro e do Leste-1 da CNBB está disponível em: http://noticias.cancaonova.com/pastoral-decatolicos-na-politica-critica-pndh-3/. Data da publicação: 24/04/2010. Acesso em 28/07/2014.

${ }^{3}$ Mensageiro do Coração de Jesus, mar./1993, p. 144.
} 
governo autoritário iniciado em 1964. Como se pôde ver no capítulo anterior, Dom Tempesta também esboça um paralelo entre o decreto presidencial e o regime militar. Após fazer essa comparação, o arcebispo do Rio de Janeiro enfatiza o quanto vários setores da Igreja lutaram pelo fim da ditadura. Também o pronunciamento referente ao PNDH-3 assinado por mais de quarenta bispos diz que, ao criticar o documento, os religiosos apenas seguem a sua "tradição profética", a mesma que se manifestou em favor da democracia nos momentos de falta de liberdade. Em continuidade, a $48^{\mathrm{a}}$ Assembleia Geral da $\mathrm{CNBB}$, em sua declaração a respeito do Programa, procurou realçar a luta empreendida pelo episcopado contra a tortura de perseguidos políticos e em prol da redemocratização iniciada na década de 1980 .

As palavras eclesiásticas deveriam ser levadas em conta e seriam dignas de reconhecimento uma vez que se sabe qual foi a louvável postura de diversos sacerdotes ao longo dos anos de repressão militar, quando figuras religiosas de destaque concederam espaço, em suas ações pastorais, à questão dos direitos humanos, relacionando tais direitos às necessidades, que se faziam urgentes, de libertação dos presos políticos, os quais tinham sido rebaixados a situações degradantes de encarceramento e suplício. Há aí, novamente, um afastamento em relação aos discursos do catolicismo conservador. A reputação cultivada pela Igreja no período ditatorial é que faria com que os bispos merecessem ser ouvidos em seu protesto contra o PNDH-3. O episcopado deveria ter, sim, as suas ordens acatadas, mas não porque a Igreja é a "depositária infalível da verdade”. O crédito reclamado pelo clero é relativo ao histórico político da Igreja e nada se deve à sua vocação divina.

Essa lembrança, por parte do episcopado, de tempos em que a "Igreja brasileira era provavelmente a mais do progressista do mundo" (Mainwaring, p. 265) revela um afastamento do clero em relação ao conservadorismo. Mas não só. A recordação mostra também que os líderes eclesiásticos atuais não abandonaram, ao menos no campo do discurso, todo o legado da "Igreja popular". A "ofensiva vaticana" (Della Cava, 1985) retirou as CEBs e a teologia da libertação de seus protagonismos de outrora, porém essa retomada iniciada por João Paulo II resultou numa realidade clerical que escapa a definições apressadas. Os bispos não só não manifestam um retorno à Igreja anterior ao Concílio Vaticano II, como também não rejeitam completamente a herança do catolicismo de esquerda que vigorou no 
período militar. Enfim, o caso do PNDH-3 mostra que, ao chamar a Igreja contemporânea de conservadora, faz-se uso de uma classificação que destoa da realidade que se viu na polêmica em análise.

Da mesma forma, dizer que houve um recuo da secularização seria igualmente destoante em relação aos fatos mostrados no episódio investigado. Não dá para falar, pura e simplesmente, em processo de dessecularização porque se presenciou uma grande participação política da religião. Há de se observar o tipo de influência que a Igreja tentou exercer sobre o poder público. Ao menos no caso do Programa Nacional, o episcopado atuou politicamente sem recorrer a argumentos de viés sagrado. Nas tentativas de derrubar as medidas do PNDH-3 que iam contra os seus ideários, os bispos procederam enquanto membros da sociedade civil que vivem numa democracia. Não houve contraposição à laicidade do ordenamento normativo da vida social; não houve recurso a uma autoridade metafísica que fosse para além da própria sociedade. 


\section{Referências bibliográficas}

ADORNO, Sérgio (2010), "História e desventura: O $3^{\circ}$ Programa Nacional de Direitos Humanos". Revista Novos Estudos Cebrap, nº. 86. São Paulo, Cebrap: pp. 05-20.

ARON, Raymond (2002), As Etapas do Pensamento Sociológico. São Paulo: Martins Fontes.

ÁVILA, Maria Betânia, PORTELlA, Ana Paula \& FERREIRA, Verônica (orgs.) (2005), Novas legalidades e democratização da vida social: família, sexualidade e aborto. Rio de Janeiro, Garamond.

AZZI, Riolando; GRIJP, Klaus Van Der (2008), História da Igreja no Brasil: ensaio de interpretação a partir do povo. Terceira época: 1930-1964. Petrópolis, Vozes.

BARRET, Justin (2012), Born believers: The science of children's religious belief. Nova York, Free Press.

BAUMAN, Zygmunt (2003), Modernidade Líquida. Rio de Janeiro, Zahar.

BERGER, Peter L. (1985), O dossel sagrado: Elementos para uma teoria sociológica da religião. São Paulo, Paulus.

BERGER, Peter L. (1999), "The Desecularization of the World: A Global Overview". In: BERGER, Peter L. (Org.), The Desecularizaton of the World: Resurgent Religion and World Politics. Grand Rapids, Ethic and Politic Policy Center and W. B. Eerdmans Publishing Company.

BERIAIN, J. (2005), Modernidades en disputa. Barcelona, Anthropos.

BOURDIEU, Pierre (2002), A dominação masculina. Rio de Janeiro, Bertrand Brasil.

BRUCE, S. (2002), God Is Dead: Secularization in the West. Oxford, Blackwell.

BURITY, Joanildo A. (2001a), "Religião e política na fronteira: desinstitucionalização e deslocamento numa relação historicamente polêmica". Rever - Revista de Estudos da Religião, n. 4, São Paulo, PUC-SP: pp. 27-45.

BURITY, J (2001b), “Globalização e identidade: desafios do multiculturalismo". In: Trabalhos para discussão. Recife, Fundação Joaquim Nabuco, n. 107. Não paginado. Disponível em: http://www.fundaj.gov.br/tpd/107.html. Acesso em 20/03/2014.

CALDWELL, Christopher (2010), Reflections on the revolution in Europe: Immigration, Islam and the West. Nova York, First Anchor.

CARRANZA, Brenda (2000), Renovação carismática católica: origens, mudança e tendências. Aparecida, Santuário.

CARVAlHO, José Murilo de (2008), Cidadania no Brasil: O longo caminho. Rio de Janeiro, Civilização Brasileira.

CASANOVA, J. (1994), Public religions in the modern World. Chicago, The University of Chicago Press.

CASANOVA, J. (2007), "Reconsiderar la secularización: una perspectiva comparada mundial". Revista Académica de Relaciones Internacionales, n. 7, Madrid, Grupo de Estudios de Relaciones Internacionales (GERI): pp. 1-20. 
CASTRO, Egardo (2009), Vocabulário de Foucault: Um percurso pelos seus temas, conceitos e autores. Belo Horizonte, Autêntica.

CATTONI DE OLIVEIRA, M. A.; GOMES, David Francisco Lopes (2011), “A justiça e a democracia como hipérbole: o PNDH-3 e o projeto constituinte do Estado Democrático de Direito entre nós". Revista de Estudos Constitucionais, Hermenêutica e Teoria do Direito, v. 3. São Leopoldo, Unisinos: p. 95-101.

COLLIOT-THÉLÈNE, Catherine. (1992), Le désenchantement de l'État: de Hegel à Max Weber. Paris, Minuit.

CURRAN, Charles E. (2002), Catholic social teaching: a historical, theological and ethical analysis. Washington, Georgetown University Press.

DAWSON, Lorne (2006), Comprehending Cults: The Sociology of New Religious Movements. Oxford, Oxford University Press

DELLA CAVA, Ralph (1985), “A ofensiva vaticana”. Religião e Sociedade, v. 12, n. 3, Rio de Janeiro, Centro de Estudos da Religião: pp. 34-53.

DUARTE, Tatiane (2013), "Cultura religiosa e direitos humanos no cotidiano do legislativo brasileiro". Revista Cultura y Religión, vol. VII/ n.2, Iquique, Instituto de Estudios Internacionales: pp.156170.

ELIAS, Norbert (1997), Os Alemães. Rio de Janeiro, Jorge Zahar.

ENROTH, Ronald (2005), A Guide to New Religious Movements. Downers Grove, InterVarsity Press.

FINKE, Roger (2005), "Church Membership in America: Trends and Explanations." In: EBAUGH, Helen Rose, Handbook of Religion and Social Institutions. Nova York, Plenum Press: pp. 335-352.

FOUCAULT, Michel (1979), Microfisica do poder. Rio de Janeiro: Edições Graal.

FOUCAULT, Michel (1994), Dits et écrites IV. Paris: Gallimard.

FOUCAULT, Michel (2006), Ditos e escritos $V$. São Paulo, Forense Universitária

FOUCAULT, Michel (2012), História da sexualidade 2: O uso dos prazeres. Rio de Janeiro, Graal.

FRIGERIO, Alejandro (2008), "O paradigma da escolha racional: mercado regulado e pluralismo religioso". Tempo Social, Revista de Sociologia da USP, vol.20, n.2, São Paulo, USP, FFLCH: pp. 17-39.

GHERALDINI, Brunero (2011), Concílio Ecumênico Vaticano II: Um debate a ser feito. Brasília, Editora Pinus.

GILL, Anthony (1998), Rendering unto Ceasar: The Roman Catholic Church and the State in Latin America. Chicago, University of Chicago Press.

GILL, Anthony (2005), The political origins of religious liberty. Nova York, Cambridge University Press.

GIUMBELLI, E. (2008), “A presença do religioso no Espaço Público: modalidades no Brasil”. Religião e Sociedade, vol. 28, n.2, Rio de Janeiro, ISER: pp. 80-100. 
GIUMBELLI, E. (2012), "Crucifixos em recintos estatais e monumento do Cristo Redentor: Distintas relações entre símbolos religiosos e espaços públicos". In: Oro, A.; Steil, C.A.; Cipriani, R.; Giumbelli, E. (Org.), A Religião no Espaço Público: Atores e Objetos. São Paulo: Terceiro Nome: pp. 45-60.

GORSKI, Philip; ALTINORDU, Ates (2008). “After secularization?” Annual Review of Sociology, v. 34, n. 1, Palo Alto, Annual Reviews: pp. 55-85.

GRIM, Brian; FINKE, Roger (2011), The Price of Freedom Denied: Religious Persecution and Conflict in the 21 st Century. Nova York, Cambridge University Press.

GRINBERG, Lucia (1999), "República Católica, o monumento ao Cristo Redentor do Corcovado". In: KNAUSS, Paulo (org), Cidade Vaidosa: imagens urbanas do Rio de Janeiro. Rio de Janeiro, Sette Letras, pp. $57-72$.

HABERMAS, Jürgen; RATZINGER, Joseph (2007), Dialética da Secularização: Sobre razão e religião. Aparecida, Idéias.

HERVIEU-LÉGER, Danièle (1999), “O bispo, a Igreja e a modernidade”. In: LUNEAU, René \& MICHAEL, Patrick (orgs.), Nem todos os caminhos levam à Roma. Petrópolis, Vozes: pp. 291322.

HERVIEU-LÉGER, Danièle (2003), Catholicisme, la fin d'un monde. Paris, Bayard.

HIGUET, Etienne (2002). "Alguns aspectos do catolicismo brasileiro atual: Considerações a partir da visão da modernidade em Paul Tillich". In: Revista Eletrônica Correlatio, n. 1. Não paginado. Disponível em: http://www.metodista.br/correlatio/num_01/a_higuet.htm. Data da publicação: abril de 2012. Acesso em 22/07/2014.

HOBSBAWN, Eric (1984), The invention of tradition. Cambridge/ London/NY, Cambridge University Press, 1984.

HOLANDA, S.B. (2010), Raízes do Brasil. São Paulo: Companhia das Letras.

IANNACCONE, Laurence (2005), "Economy". In: EBAUGH, Helen Rose, Handbook of Religion and Social Institutions. Nova York, Plenum Press: pp. 21-40.

IGNATIEFF, Michael (2000). Isaiah Berlin: uma vida. Rio de Janeiro: Record.

LACLAU, E. (2011), La razón populista. Buenos Aires, Fondo de Cultura Económica.

LEFEBVRE (1991), Do liberalismo à apostasia. Rio de Janeiro, Permanência.

LEME, S. (1916), Carta pastoral de Dom Sebastião Leme, arcebispo metropolitano de Olinda, saudando os seus diocesanos. Petrópolis: Vozes

LÓPEZ, Francisco (2004). "Movimientos de laicos, secularización y función pública de la religión". Revista Persona y Sociedad. 18 (3). Santiago: Universidad Alberto Hurtado.

LÖWY, Michael (2000), A guerra dos deuses: religião e política na América Latina. Petrópolis, Vozes.

MAFRA, Clara (2011). "A 'arma da cultura' e os 'universalismos parciais"”. Mana, vol.17, n.3, pp. 607-624.

MAINWARING, Scott (1989), Igreja Católica e política no Brasil (1916-1985). São Paulo, Editora Brasiliense.

MARIANO, Ricardo (2001). Análise sociológica do crescimento pentecostal no Brasil. Tese de doutorado. Faculdade de Filosofia, Letras e Ciências Humanas da Universidade de São Paulo. 
MARIANO, Ricardo (2011). "Laicidade à brasileira: católicos, pentecostais e laicos em disputa na esfera pública". Civitas - Revista de Ciências Sociais, vol. 11 (2). Porto Alegre, EDIPUCRS: pp.238 -258.

MANNHEIM, Karl (1981), “O pensamento conservador”. In: MARTINS, José de Souza, Introdução crítica à sociologia rural. São Paulo, Hucitec: pp. 77-131.

MARRAMAO, Giacomo (1983), Potere e secolarizzazione: le categorie del tempo. Roma, Editiori Riuniti.

MARTELLI, Stefano. (1995), A religião na sociedade pós-moderna: entre secularização e dessecularização. São Paulo, Edições Paulinas.

MICHAEL, Patrick (1999), "O último papa: Reflexões sobre a utilização do político sob o pontificado de João Paulo II". In: LUNEAU, René \& MICHAEL, Patrick (orgs.), Nem todos os caminhos levam à Roma. Petrópolis, Vozes: pp. 345-368.

MONTERO, Paula (2006), "Religião, pluralismo e esfera pública no Brasil." Revista Novos Estudos Cebrap, ${ }^{\circ}$. 74. São Paulo, Cebrap: p.47-65.

MONTERO, Paula (2009), "Secularização e espaço público: a reinvenção do pluralismo religioso no Brasil”. Etnográfica, vol.13, n.1. Lisboa, CRIA: pp. 7-16.

MONTERO, Paula (2012), "Controvérsias religiosas e esfera pública: repensando as religiões como discurso". Religião e sociedade, vol.32, n.1. Rio de Janeiro, ISER: pp. 167-183.

NIETZSCHE, Friedrich (1992), O nascimento da tragédia. São Paulo, Cia. das Letras, 1992.

OLIVEIRA, Eliane Martins de (2009), A "vida no espírito" e o dom de ser "Canção Nova”. Aparecida, Ideias e Letras.

OLIVEIRA, V. V. (2013), Direitos Humanos e suas justificativas na mídia: a controvérsia envolvendo o caso do PNDH-3. Dissertação de mestrado. Faculdade de Filosofia e Ciências Humanas da Universidade Federal de Minas Gerais.

PIERUCCI, Antônio Flávio (1996), "Liberdade de Cultos na Sociedade de Serviços: Em Defesa do Consumidor Religioso", Revista Novos Estudos CEBRAP, no 44. São Paulo, Cebrap: pp. 3-11.

PIERUCCI, Antônio Flávio (1997), "A propósito do auto-engano em sociologia da religião". Revista Novos Estudos Cebrap, nº. 49. São Paulo, Cebrap: pp. 99-117.

PIERUCCI, Antônio Flávio (1998), "Secularização em Max Weber: da contemporânea serventia de voltarmos a acessar aquele velho sentido". Revista Brasileira de Ciências Sociais, 13 (37). São Paulo, RBSC: pp. 43-73.

PIERUCCI, Antônio Flávio (2003), O desencantamento do mundo: todos os passos do conceito em Max Weber. São Paulo, Editora 34.

PIERUCCI, Antônio Flávio (2008a), "De olho na modernidade religiosa". Tempo Social, Revista de Sociologia da USP, vol.20, n.2. São Paulo, USP: pp.9-15.

PIERUCCI, Antônio Flávio (2008b), "Secularização e declínio do catolicismo", In: Souza, Beatriz Muniz de; Martino, Luís Mauro Sá. (Org.), Sociologia da Religião e Mudança Social: católicos, protestantes e novos movimentos religiosos no Brasil. São Paulo, Paulus: pp. 11-21.

PIERUCCI, Antônio Flávio (2011), "Eleição 2010: Desmoralização eleitoral do moralismo religioso". Revista Novos Estudos Cebrap, nº. 89. São Paulo, Cebrap: pp. 6-15. 
PIO X, papa (2005), Terceiro catecismo da doutrina cristã. Campos: Serviço de animação eucarística mariana.

PIO XI (1950), Sobre Cristo Rei. Petrópolis, Vozes, 1950.

PONDÉ, Luiz Felipe (2011), Catolicismo hoje. São Paulo, Benvirá.

POULAT, Emile (1986), Les discours sur les droits de l'homme: ses paradoxes et ses contraintes, extrait. Actes de la IIIéme Recontre of Man: its Paradoxes and Limits. Tunis, Centre D'Etudes et Recherches Economiques et Sociales.

PRANDI, Reginaldo (1997), Um sopro do Espírito: a renovação conservadora do catolicismo carismático. São Paulo, Edusp/Fapesp.

ROCHA, João Cezar de Castro (2003), "Nenhum Brasil existe: poesia como história cultural". In: Nenhum Brasil Existe - Pequena Enciclopédia. Rio de Janeiro, UniverCidade Editora.

ROSADO-NUNES, Maria José (2008), "Direitos, cidadania das mulheres e religião". Tempo Social, Revista de Sociologia da USP, vol.20, n.2. São Paulo, USP: pp. 67-79.

SAID, Edward W (2007), Orientalismo: o Oriente como invenção do Ocidente. São Paulo, Companhia das Letras.

SANTO ROSÁRIO, Maria Regina (1962). O Cardeal Leme (1882-1942). Rio de Janeiro, Livraria José Olympio.

SMITH, Adam (2003), A Riqueza das Nações. São Paulo, Martins Fontes.

SMITH, C. (2003), The Secular Revolution: Power, Interests, and Conflict in the Secularization of American Public Life. Berkeley: Univ. Calif. Press.

STARK, Rodney (1999), “Secularization, RIP”. Sociology of Religion. 60 (3). Nova York, Oxford University Press: pp. 249-273

STARK, Rodney (2008), What Americans really believe. Waco, Baylor University Press.

STARK, Rodney; BAINBRIDGE, William (1987), A Theory of Religion. New York: Peter Lang.

STARK, Rodney; FINKE Roger (2000), Acts of Faith: Explaining the Human Side of Religion. Berkeley: University of California Press.

STRAUSS, Leo (2009), Direito Natural e História. Lisboa, Edições 70, 2009.

TROELTSCH, Ernst (2012), Protestantism and progress: A historical study of the relation of protestantism to the modern world. Nova York, AMA Publication.

WARNER, Stephen (1993), "Work in progress towards a new paradigm for the sociological study of religion in the United States". American Journal of Sociology, vol. 98, n. 5. Chicago, The University of Chicago Press: pp. 1044-1093.

WARNER, Stephen (1997), "Convergence toward a new paradigm: A case of induction". In YOUNG, Lawrence, Rational choice theory and religion. Nova York, Routledge: pp. 87-104

WEBER, Max (1965), Essais sur la théorie de la science. Paris: Plon.

WEBER, Max (1969), Economía y sociedad. Esbozo de sociología comprensiva. 2 vols. Ciudad de México, Fondo de Cultura Económica.

WEBER, Max (1970), A política como vocação. Ciência e política, duas vocações. São Paulo: Cultrix. 
WEBER, Max (1979), "Rejeições religiosas do mundo e suas direções". In: GERTH, Hans; MILLS, Wright. Max Weber. Ensaios de Sociologia. Rio de Janeiro, Zahar: pp. 371-410

WEBER, Max (1982), Ensaios de sociologia. Rio de Janeiro, LTC Editora, 1982.

WILSON, Bryan (1982), Religion in sociological perspective. Oxford, Oxford University Press. 